\title{
Digital Commons@
}

\section{Loyola Marymount University}

LMU Loyola Law School

\section{English Learner Master Plan Playbook: Developing Equitable Local Policies for Multilingual and English Learners Students}

\author{
Elvira G. Armas, Ed.D \\ Loyola Marymount University, Elvira.Armas@Imu.edu \\ Magaly Lavadenz, Ph.D. \\ Loyola Marymount University, magaly.lavadenz@Imu.edu
}

Natividad Rozsa, M.A.

Los Angeles Unified School District

Gisela O'Brien, Ph.D.

Loyola Marymount University, Gisela.Obrien@Imu.edu

Follow this and additional works at: https://digitalcommons.Imu.edu/ceelreports

Part of the Bilingual, Multilingual, and Multicultural Education Commons

\section{Recommended Citation for Full Report}

Armas, Ed.D, Elvira G.; Lavadenz, Ph.D., Magaly; Rozsa, M.A., Natividad; and O'Brien, Ph.D., Gisela, English Learner Master Plan Playbook: Developing Equitable Local Policies for Multilingual and English Learners Students (2021). doi: 10.15365/ceel.elmasterplan2021

This Book is brought to you for free and open access by the Center for Equity for English Learners at Digital Commons @ Loyola Marymount University and Loyola Law School. It has been accepted for inclusion in Reports by an authorized administrator of Digital Commons@Loyola Marymount University and Loyola Law School. For more information, please contact digitalcommons@lmu.edu. 

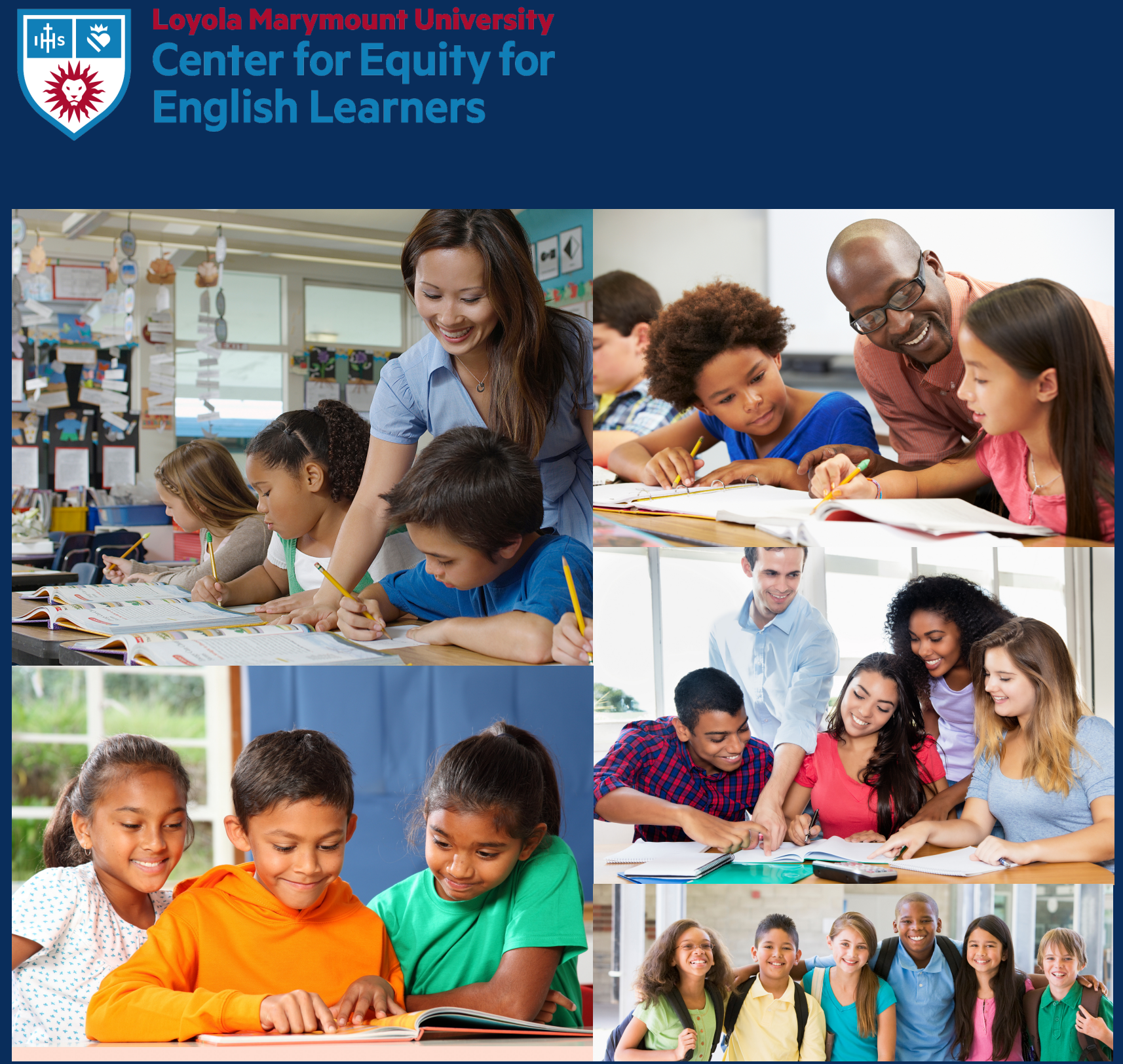

\section{ENGLISH LEARNER MASTER PLAN PLAYBOOK}

Developing Equitable Local Education Policies for Multilingual and English Learner Students 
The Center for Equity for English Learners at Loyola Marymount University upholds equity and excellence for Multilingual/English Learner students by transforming educational systems and practices in California and throughout the nation.

CEEL offers innovative, high-quality programs that are research-based and co-constructed with our partners. CEEL's nationally recognized experts support the work of schools, school systems, educational/community organizations, and policy makers through an assets-based approach to serve the unique academic, social, and language needs of linguistically and culturally diverse students.

\section{CENTER FOR EQUITY FOR ENGLISH LEARNERS | CEEL}

Loyola Marymount University

School of Education

Los Angeles, California

Website: https://soe.Imu.edu/ceel

Email: ceel@Imu.edu

(C202 I, Center for Equity for English Learners

All rights reserved. No part of this publication may be reproduced or transmitted in any form unless used for designated educational and non-profit purposes. Except for these uses, no part of this playbook may be reproduced or used in any form or by any means, electronic, or mechanical, including through any retrieval or photocopying system without written permission.

\section{RECOMMENDED CITATION:}

Armas, E., Lavadenz, M., Rozsa, N., \& O’Brien, G. (202I). English Learner Master Plan Playbook: Developing Equitable Local Policies for Multilingual and English Learner Students. Loyola Marymount University Center for Equity for English Learners. 


\section{TABLE OF CONTENTS}

Introduction

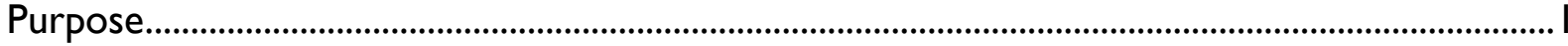

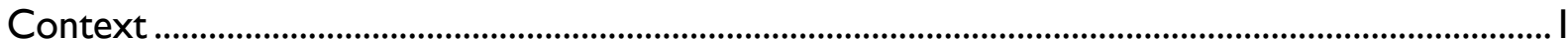

Why an English Learner Master Plan? ...................................................................................................

CA English Learner Roadmap Alignment.............................................................................................

Playbook Overview..............................................................................................................................

EL Master Plan Development: Steps, Tools, and Timeframe ...........................................................6

Tools for Setting the Course .............................................................................................................

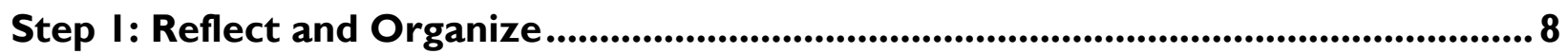

Tool \#I: Reflection: Start Where You Are .......................................................................................

Tool \#IA. Review LEA Vision and Mission for English Learner Education ............................... 10

Tool \#IB. Identify Stakeholders .................................................................................................. 12

Tool \#IC. Build Context................................................................................................................ 14

Step 2: Engage in Inquiry, Manage Project, and Launch Development...................... 15

Considerations for Inquiry and Project Management .................................................................... 16

Tool \#2: Inquiry and Management ................................................................................................. 21

Step 3: Conduct Iterative Writing and Feedback Sessions .............................................2 23

Tool \#3: Chapter Analysis, Reflection and Evaluation (CARE).................................................. 23

Component \#I - Commitment and Purpose.................................................................................... 25

Component \#2 - Responding to Diverse Learners ...................................................................... 28

Component \#3 - Program Options ................................................................................................. 31

Component \#4 - Staffing .............................................................................................................. 34

Component \#5 - Access to Core Curriculum …………………………………………………..... 37

Component \#6 - English Language Development................................................................................ 40

Component \#7 - Professional Learning ......................................................................................... 43

Component \#8 - Family-School Partnerships............................................................................... 46

Component \#9 - Assessment and Student Monitoring ..................................................................... 49

Component \#10 - Program Monitoring and Evaluation ................................................................. 52

Conclusion: The Importance of Leadership.................................................................................... 55 


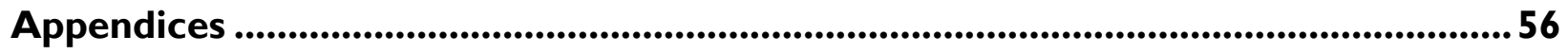

Appendix I. Equitable, Coherent, and Sustainable Systems ........................................................... 56

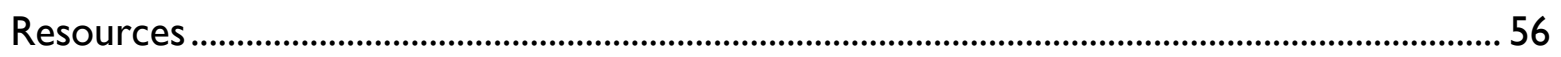

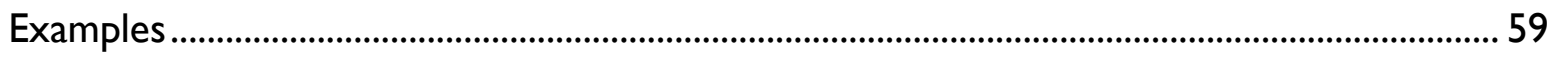

Appendix 2. Equity-Driven Processes, Research-based Programs and Practices ......................... 72

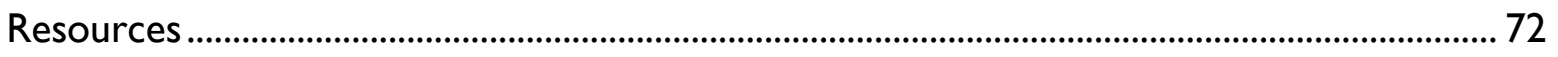

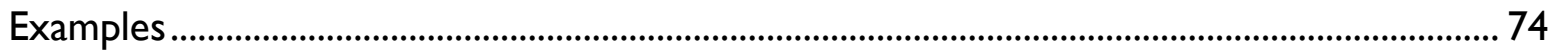

Appendix 3: Family-Community Engagement ……………………………………………........ 85

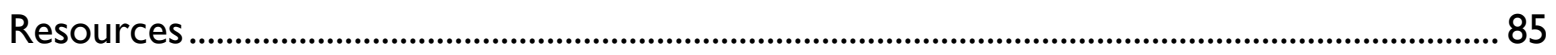

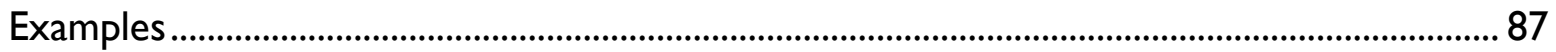

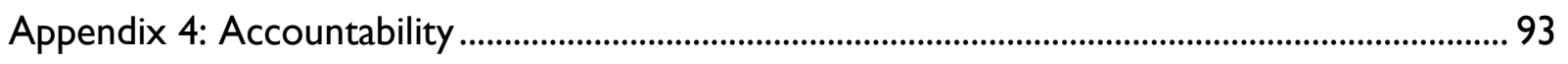

Resources ............................................................................................................................... 93

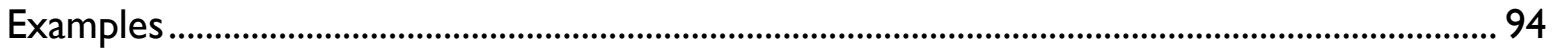

Appendix 5: Other Guidance and Resources ........................................................................... 104

About the Authors ...................................................................................................................... 107 


\section{INTRODUCTION}

\section{PURPOSE}

The commitment to educational equity for Multilingual/English Learner students' requires visionary policy, strategic planning, and bold leadership that responds to the moral and legal imperative to foster equity mind-sets ${ }^{2}$ and enable systems to welcome and embrace the cultural, linguistic, social, and creative capital our diverse English Learners (ELs) bring to the educational context. The English Learner Master Plan Playbook provides tools for educators, families, and community members to engage in policy dialogues and development processes to support the creation of a local policy document - the English Learner Master Plan - to articulate the Local Education Agency's (LEAs) ${ }^{3}$ mission and vision for all ELs to be socially, linguistically, and academically proficient. An English Learner Master Plan (EL Master Plan) policy also promotes equitable practices for ELs to develop $21^{\text {st }}$ century skills ${ }^{4}$ to contribute positively to our diverse local and global communities.

"Educational equity is when each and every student is provided the academic, social, emotional, cultural, linguistic, and other opportunities, resources, and supports that they specifically need, when they need them, to experience belonging in school, achieve academic success, and attain self-actualization. California's commitment to equity and social justice is illustrated in its policies, standards, frameworks, and resources..."

- California Department of Education (2020, page 54)

Source: Improving Education for Multilingual and English Learner Students: Research to Practice. Sacramento, CA.

\section{CONTEXT}

The education of ELs is impacted by policies at the federal, state, and local levels. Over the past decade California has experienced educational policy shifts and implementation of new initiatives and reforms including the adoption of Common Core State Standards, California State Seal of Biliteracy (20I2), California English Language Development (ELD) Standards (20I2), and the publication of California's English Language Arts/English Language Development Framework (20l4).

\footnotetext{
' We use the term "English Learners" as the federal policy, legislation, and court cases term used for this protected group of students. As such, we acknowledge and encourage the use of the terms "Multilingual Learners" and "Emergent Bilingual Learners" that focus on the potential for multilingualism and position bilingualism as a resource, both cognitively and socially (CDE, 2020; García, 2009).

${ }^{2}$ Dweck, C. S. (2007). Mindset: The new psychology of success. New York: Ballantine Books.

${ }^{3}$ Local educational agencies are defined in state law as school districts, county offices of education and charter schools. We use the term LEA and districts interchangeably.

${ }^{4}$ P2I Network, Battelle for Kids (2019). Framework for $21^{\text {st }}$ Century Learning. http://static.battelleforkids.org/documents/p2I/P2I_Framework_Brief.pdf
} 
The reauthorization of the Elementary and Secondary Education Act (ESEA) as the Every Student Succeeds Act (ESSA, 2015) ${ }^{5}$ holds LEAs, along with schools, accountable for educating ELs and includes requirements for standardization of identification and reclassification processes for ELs. However, LEAs must be guided by more than federal, state, and legal mandates. Local policy documents such as an EL Master Plan have the potential to be bold, visionary, and aspirational.

With the passage of Proposition 58 (California Ed.G.E. - Education for a Global Economy, 2016), Californians overwhelmingly (73.5\%) repealed Prop 227 and overturned 18 years of restrictive language policies. This was followed by the historic state board of education's adoption of the California English Learner Roadmap policy (2017), and the publication of the Global California 2030 Initiative (2018). These most recent policies and initiatives pave the way for LEAs to recommit, reimagine, and reignite the collective will to develop and implement an LEA English Learner Master Plan that goes beyond the minimum compliance requirements and alignment to the Castañeda standard (198I), which mandates that programs for languageminority students must be: I) based on a sound educational theory, 2) implemented effectively with sufficient resources and personnel, and 3) evaluated to determine whether they are effective in helping students overcome language barriers. As a whole, federal and state guidelines comprise language and education policies that offer educators and community members the opportunity to apply and focus these in their specific contexts. ${ }^{6}$

\section{WHY AN ENGLISH LEARNER MASTER PLAN?}

Although state's roles in education vary, relevant EL research paired with federal and state mandates for EL education provide clear guidance for policy makers and educational systems to transform teaching and learning for our nation's 5 million English learners, 1.1 million of whom reside in California. The recent adoption of the CA English Learner Roadmap comprehensive policy for EL education affords LEAs the opportunity to align EL local policy to a framework that is research-based and builds upon EL strengths through coherent approaches to address key barriers in education in order to bolster EL students' educational opportunities and to create systems that support the realization of their academic, linguistic, and social potential ${ }^{7}$. The EL Master Plan serves, then, as the LEA's collective commitment to "shift the paradigm to focus on the provision of opportunities to learn for ELs."

\footnotetext{
${ }^{5}$ U.S. Department of Education: Every Student Succeeds Act (ESSA, 2015) https://www.ed.gov/essa?src=rn.

${ }^{6}$ Corson, D. (1999). Language Policy in Schools: A Resource for Teachers and Administrators. United Kingdom: Lawrence Erlbaum Associates.

${ }^{7}$ Umansky, I. M., \& Porter, L. (2020). State English learner education policy: A conceptual framework to guide comprehensive policy action.

Education Policy Analysis Archives, 28(I7). https://doi.org// 0.14507/epaa.28.4594

${ }^{8} \mathrm{https} / / \mathrm{www}$.colorincolorado.org/article/language-policy-recommendations-policymakers-and-educators
} 
Accordingly, this English Learner Master Plan Playbook proposes four essential goals for LEAs' English Learner Master Plans:

I. Create equitable, coherent, and sustainable systems of EL services

2. Develop equity-driven processes to build LEA-wide capacity to deliver researchbased programs and practices that leverage EL students' assets and address their specific needs

3. Establish effective family-community engagement systems to foster collaborative partnerships

4. Implement a local accountability model that ensures EL students' success

The tools and resources contained in this English Learner Master Plan Playbook support the development of a local policy document that addresses ten components that correspond to these four goals (see Figure I). These components can be further developed into EL Master Plan chapters, or grouped together by goal area as districts develop their EL Master Plan content.

Figure I. English Learner Master Plan Goals and Components

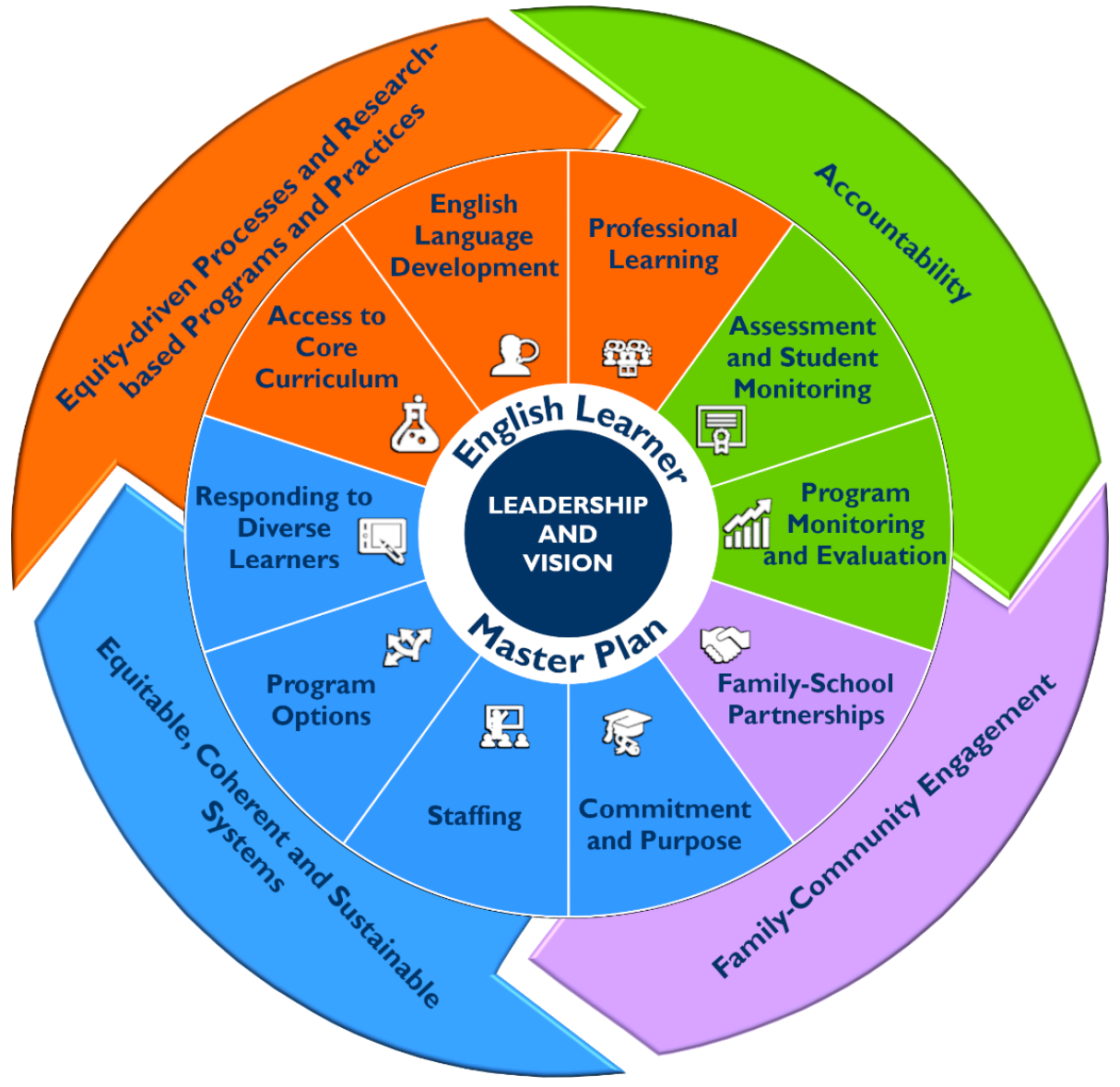


The next section describes how each of the proposed EL Master Plan components/chapters aligns with the CA English Learner Roadmap principles and elements.

\section{CA ENGLISH LEARNER ROADMAP ALIGNMENT}

The CA English Learner Roadmap (ELR) adopted in 2017 is intended to support LEAs in implementing "California's twenty-first century college and career-ready standards, curriculum, instructional programs, and assessments for English learners." Table I provides a recommended alignment with the ELR principles and corresponding elements that each EL Master Plan component, or chapter, might address.

\begin{tabular}{|c|c|c|}
\hline $\begin{array}{l}\text { Component or } \\
\text { Chapter }\end{array}$ & $\begin{array}{l}\text { CA English Learner } \\
\text { Roadmap Principle }\end{array}$ & $\begin{array}{l}\text { CA English Learner Roadmap } \\
\text { Elements }\end{array}$ \\
\hline $\begin{array}{l}\text { Commitment } \\
\text { and Purpose }\end{array}$ & $\begin{array}{l}\text { - Principle I: Assets-Oriented and } \\
\text { Needs-Responsive Schools } \\
\text { - Principle 2: Intellectual Quality of } \\
\text { Instruction and Meaningful Access } \\
\text { - Principle 3: System Conditions } \\
\text { that Support Effectiveness } \\
\text { - Principle 4: Alignment and } \\
\text { Articulation within and Across } \\
\text { Systems }\end{array}$ & $\begin{array}{l}\text { IA. Language and Culture as Assets } \\
\text { IB. English Learner Profiles } \\
\text { IC. School Climate } \\
\text { ID. Family and School Partnerships } \\
\text { 2C. High Expectations } \\
\text { 2G. Programmatic Choices } \\
\text { 3A. Leadership } \\
\text { 4A. Alignment and Articulation } \\
\text { 4C. Coherency }\end{array}$ \\
\hline $\begin{array}{l}\text { Responding to } \\
\text { Diverse } \\
\text { Learners } \\
\text { (Identification, } \\
\text { Placement, } \\
\text { Reclassification) }\end{array}$ & $\begin{array}{l}\text { Principle I: Assets-Oriented and } \\
\text { Needs-Responsive Schools } \\
\text { - Principle 2: Intellectual Quality of } \\
\text { Instruction and Meaningful Access } \\
\text { - Principle 4: Alignment and } \\
\text { Articulation within and Across } \\
\text { Systems }\end{array}$ & $\begin{array}{l}\text { IA. Language and Culture as Assets } \\
\text { IB. English Learner Profiles } \\
\text { ID. Family and School Partnerships } \\
\text { IE. English Learners with Disabilities } \\
\text { 2G. Programmatic Choice } \\
\text { 4A. Alignment and Articulation }\end{array}$ \\
\hline $\begin{array}{l}\text { Program } \\
\text { Options }\end{array}$ & $\begin{array}{l}\text { - Principle I: Assets-Oriented and } \\
\text { Needs-Responsive Schools } \\
\text { - Principle 2: Intellectual Quality of } \\
\text { Instruction and Meaningful Access } \\
\text { - Principle 4: Alignment and } \\
\text { Articulation within and Across } \\
\text { Systems }\end{array}$ & $\begin{array}{l}\text { IA. Language and Culture as Assets } \\
\text { IB. English Learner Profiles } \\
\text { ID. Family and School Partnerships } \\
\text { IE. English learners with Disabilities } \\
\text { 2E. Use of Students' Home Languages } \\
\text { 2G. Programmatic Choice } \\
\text { 4A. Alignment and Articulation } \\
\text { 4C. Coherency }\end{array}$ \\
\hline Stafifing & $\begin{array}{l}\text { Principle 3: System Conditions that } \\
\text { Support Effectiveness } \\
\text { - Principle 4: Alignment and } \\
\text { Articulation within and Across } \\
\text { Systems }\end{array}$ & $\begin{array}{l}\text { 3A. Leadership } \\
\text { 3B. Adequate Resources } \\
\text { 3D. Capacity Building } \\
\text { 4A. Alignment and Articulation } \\
\text { 4C. Coherency }\end{array}$ \\
\hline
\end{tabular}




\begin{tabular}{|c|c|c|}
\hline $\begin{array}{l}\text { Component or } \\
\text { Chapter }\end{array}$ & $\begin{array}{l}\text { CA English Learner } \\
\text { Roadmap Principle }\end{array}$ & $\begin{array}{l}\text { CA English Learner Roadmap } \\
\text { Elements }\end{array}$ \\
\hline $\begin{array}{l}\text { Access to Core } \\
\text { Curriculum }\end{array}$ & $\begin{array}{l}\text { Principle I: Assets-Oriented and } \\
\text { Needs-Responsive Schools } \\
\text { - Principle 2: Intellectual Quality of } \\
\text { Instruction and Meaningful Access } \\
\text { - Principle 4: Alignment and } \\
\text { Articulation within and Across } \\
\text { Systems }\end{array}$ & $\begin{array}{l}\text { IA. Language and Culture as Assets } \\
\text { IB. English Learner Profiles } \\
\text { IE. English Learners with Disabilities } \\
\text { 2A. Integrated and Designated English } \\
\text { Language Development } \\
\text { 2B. Intellectually Rich, Standards-based } \\
\text { Curriculum } \\
\text { 2C. High Expectations } \\
\text { 2D. Access to the Full Curriculum } \\
\text { 2E. Use of Students' Home Language } \\
\text { 2F. Rigorous Instructional Materials } \\
\text { 4A. Alignment and Articulation } \\
\text { 4C. Coherency }\end{array}$ \\
\hline $\begin{array}{l}\text { English } \\
\text { Language } \\
\text { Development }\end{array}$ & $\begin{array}{l}\text { Principle I: Assets-Oriented and } \\
\text { Needs-Responsive Schools } \\
\text { - Principle 2: Intellectual Quality of } \\
\text { Instruction and Meaningful Access } \\
\text { - Principle 4: Alignment and } \\
\text { Articulation within and Across } \\
\text { Systems }\end{array}$ & $\begin{array}{l}\text { IB. English Learner Profiles } \\
\text { IE. English learners with Disabilities } \\
\text { 2A. Integrated and Designated English } \\
\text { Language Development } \\
\text { 4A. Alignment and Articulation } \\
\text { 4C. Coherency }\end{array}$ \\
\hline $\begin{array}{l}\text { Professional } \\
\text { Learning }\end{array}$ & $\begin{array}{l}\text { - Principle 3: System Conditions that } \\
\text { Support Effectiveness } \\
\text { - Principle 4: Alignment and } \\
\text { Articulation within and Across } \\
\text { Systems }\end{array}$ & $\begin{array}{l}\text { 3A. Leadership } \\
\text { 3D. Capacity Building } \\
\text { 4A. Alignment and Articulation } \\
\text { 4C. Coherency }\end{array}$ \\
\hline $\begin{array}{l}\text { Family - School } \\
\text { Partnerships }\end{array}$ & $\begin{array}{l}\text { Principle I: Assets-Oriented and } \\
\text { Needs-Responsive Schools } \\
\text { - Principle 3: System Conditions that } \\
\text { Support Effectiveness } \\
\text { - Principle 4: Alignment and } \\
\text { Articulation within and Across } \\
\text { Systems }\end{array}$ & $\begin{array}{l}\text { ID. Family and School Partnerships } \\
\text { 3A. Leadership } \\
\text { 4A. Alignment and Articulation } \\
\text { 4C. Coherency }\end{array}$ \\
\hline $\begin{array}{l}\text { Assessment and } \\
\text { Student } \\
\text { Monitoring }\end{array}$ & $\begin{array}{l}\text { Principle 3: System Conditions that } \\
\text { Support Effectiveness } \\
\text { - Principle 4: Alignment and } \\
\text { Articulation within and Across } \\
\text { Systems }\end{array}$ & $\begin{array}{l}\text { 3A. Leadership } \\
\text { 3C. Assessments } \\
\text { 4A. Alignment and Articulation } \\
\text { 4C. Coherency }\end{array}$ \\
\hline $\begin{array}{l}\text { Program } \\
\text { Monitoring and } \\
\text { Evaluation }\end{array}$ & $\begin{array}{l}\text { - Principle 3: System Conditions that } \\
\text { Support Effectiveness } \\
\text { - Principle 4: Alignment and } \\
\text { Articulation within and Across } \\
\text { Systems }\end{array}$ & $\begin{array}{l}\text { 3A. Leadership } \\
\text { 3B. Adequate Resources } \\
\text { 3C. Assessments } \\
\text { 4A. Alignment and Articulation } \\
\text { 4C. Coherency }\end{array}$ \\
\hline
\end{tabular}




\section{PLAYBOOK OVERVIEW}

The English Learner Master Plan Playbook is organized into 3 key steps, tools and timeframe to support LEA teams EL Master Plan development processes from start to finish as illustrated in Figure 2. We provide an introduction that addresses the policy context and ELR alignment. Step I prompts LEA leadership teams to initiate the EL Master Plan development process by engaging in reflection and organization activities using Tool \#I: Reflection: Start Where You Are to launch their EL Master Plan project. Step 2 delineates suggested strategies for project inquiry and management using Tool \#2: Inquiry and Management; this tool can be used throughout the EL Master Plan development process. Step 3 introduces Tool \#3: Chapter Analysis Reflection and Evaluation (CARE), intended to assist LEA leadership teams and lead writers in developing and refining their EL Master Plan chapters. Several appendices provide examples from six English Learner Master Plans across the state and highlight resources to support EL Master Plan content development.

\section{EL MASTER PLAN DEVELOPMENT: STEPS, TOOLS, AND TIMEFRAME}

LEAs engaged in the development of an EL Master Plan have the opportunity to recommit, reimagine, and reignite their collective will to develop and implement an LEA EL Master Plan that goes beyond the minimum compliance requirements. This thoughtful work requires time. "Go slow to go fast," is a commonly heard maxim that should be applied to the creation of an EL Master Plan.

\section{English Learner Master Plan Development Timeframe}

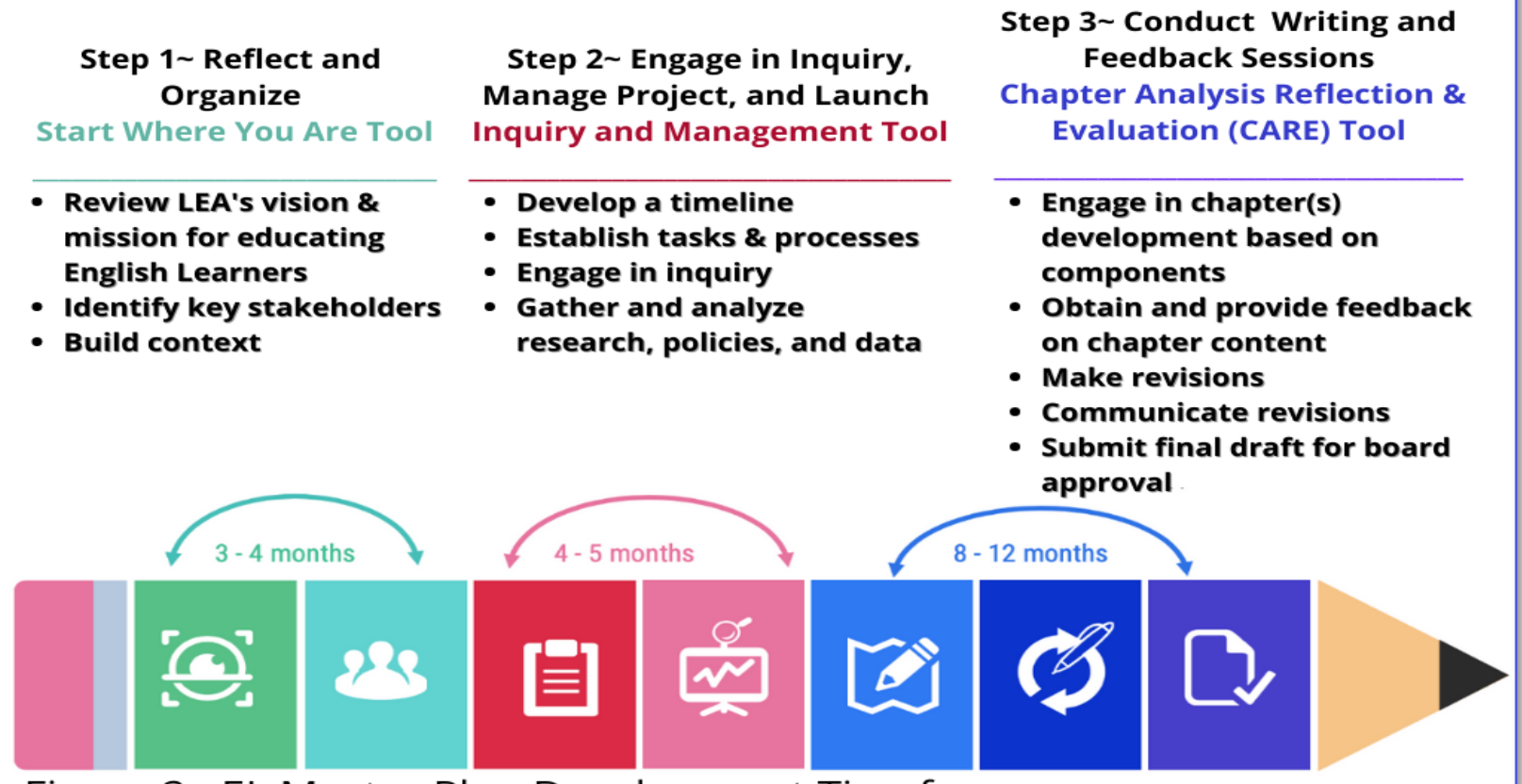

Figure 2. EL Master Plan Development Timeframe 
The recommended timeframe (see Figure 2) includes three major steps that include: (I) foundational work in the first 3-4 months, (2) inquiry and management processes in the next 45 months, and (3) iterative input, writing, and feedback cycles in the final 8-12 months.

Depending on the size of your district and the number of stakeholders you engage, the entire project may take up to two years, with the majority of the time dedicated to the writing and feedback cycles that will include stakeholder engagement, progress updates, content development and revisions, and final reviews prior to presenting to the board for approval.

\section{TOOLS FOR SETTING THE COURSE}

The English Learner Master Plan Playbook offers three tools to set the course for the development of a comprehensive and rigorous EL Master Plan.

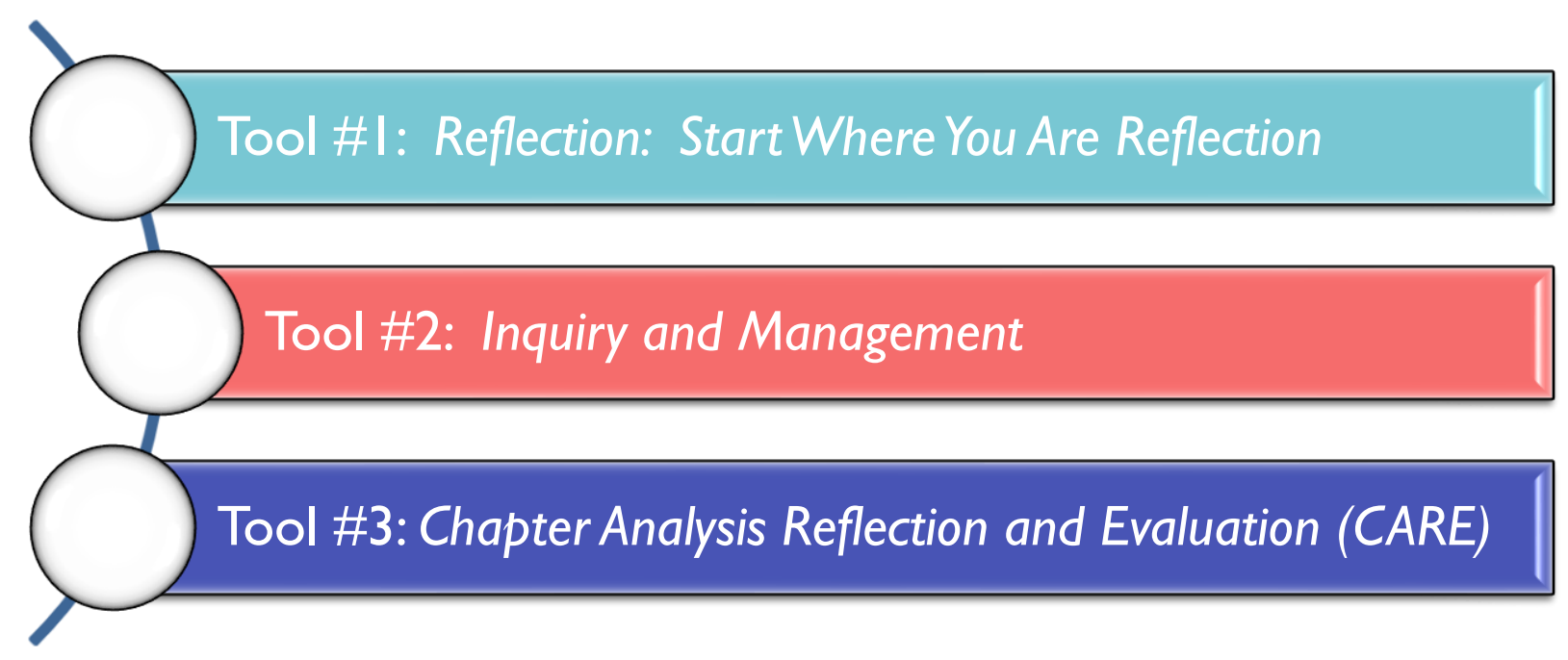

Tool \#I: Reflection: Start Where You Are is foundational and thus is recommended for use as a first step in the EL Master Plan development process. The Inquiry and Management Tool (Tool \#2) is proposed for use throughout the project and is a companion to the CARE Tool (Tool \#3). These two tools work in concert and are designed to be utilized multiple times to reflect on development progress, quality of the document, and communication protocols to map completion benchmarks. Together, these tools support iterative processes to design, monitor and complete EL Master Plan development and communication. All tools are intended for use by district leadership teams and stakeholders involved in the development of the EL Master Plan: teachers, coaches, parents, and leaders at the LEA central office and site-levels. We invite you to engage your colleagues in the exploration and use of this EL Master Plan Playbook as you design or refine equitable local policies for Multilingual/English Learner students in your context. 


\section{STEP I: REFLECT AND ORGANIZE}

TOOL \#I: REFLECTION: START WHERE YOU ARE

As LEA teams begin their EL Master Plan development or revision journey, we recommend that the first step consist of thoughtful reflection about the current state of the LEA's policies, programs, and practices related to English Learner education. Reflection allows teams to identify strengths in their LEA context to effectively "start where you are" while simultaneously elevating priority areas and action steps to guide the EL Master Plan development processes. The success of the EL Master Plan project and effective stakeholder engagement will also be dependent on thorough organization and establishing project

"Without reflection, we go blindly on our way, creating more unintended consequences, and failing to achieve anything useful."

\section{-Margaret J. Wheatley} management processes. Accordingly, the purpose of Tool \#I: Reflection: Start Where You Are, is to ensure that leadership teams prioritize reflection and understanding of existing policies and practices to support English Learner success in their Local Education Agencies (LEAs).

Figure 3 - Tool \#I Outcomes

Using Tool \#I affords LEA lead teams the opportunity to identify:

- Alignment between the existing LEA's vision for English learners, the existing English Learner Master Plan (if available), and the CA English Learner Roadmap policy.

- Action steps to develop or refine your LEA's vision for English Learner education.

- Key leaders and stakeholders essential to successfully develop an English Learner Master Plan.

- Action steps to refine descriptions of English Learner policies, programs, and services aligned with the CA English Learner Roadmap policy.
The Reflection tool is designed to be used prior to beginning the EL Master Plan writing processes. Figure 3 highlights expected outcomes for LEA teams who employ the use of this tool, intended to support the LEA administration team's reflection on the process, culture, and other LEA infrastructural elements. This reflection process serves as a springboard for developing and writing the EL Master Plan. As such, this first step in developing an EL Master Plan requires reflecting on existing LEA policies,

procedures, systems, and practices that will influence the content of the EL Master Plan. These activities engender discussions and conversations that are critical to arrive at a better 
understanding of the LEA's current structures to support the education of English Learner students.

Tool \# I: Reflection: Start Where You Are is comprised of three parts: Tool \#IA) Review the LEA's vision and mission for educating English learners, Tool \#IB) Identify key stakeholders, and Tool \#IC) Build the context needed to embark on the development of the plan. Figure 4 provides an overview of the interrelated parts of the tool. These three parts work together to provide the user with the specific purpose for each along with a list of items/actions required to prepare for the use of the tool and a specified purpose. We also offer suggested reflection questions to support discussion and to record thoughts, ideas, wonderings, and action steps.

Figure 4. Overview of Tool \#I: Reflection: Start Where You Are

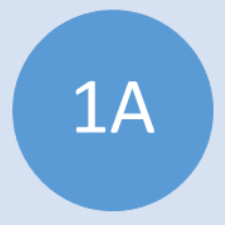

Tool \# I A

Review LEAVision and Mission for EL Education

- Asset-based Orientation

- Alignment with EL Roadmap \& LEA

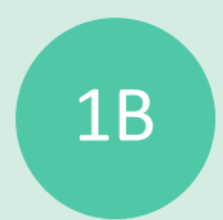

Tool \#IB

Identify Stakeholders

- Project Management Team

- LeadWriters

- EL Expertise

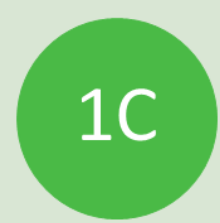

Tool \#IC

Build Context

- Existing EL programs \& Services

- Existing EL policies or Master Plan 


\section{TOOL \# I A. REVIEW LEA VISION AND MISSION FOR ENGLISH LEARNER EDUCATION}

The California English Learner Roadmap (ELR) Policy (2017) asserts the following mission and vision for English Learner education. Read the statements below in preparation for examining your LEA's existing vision and mission for the education of English learners.

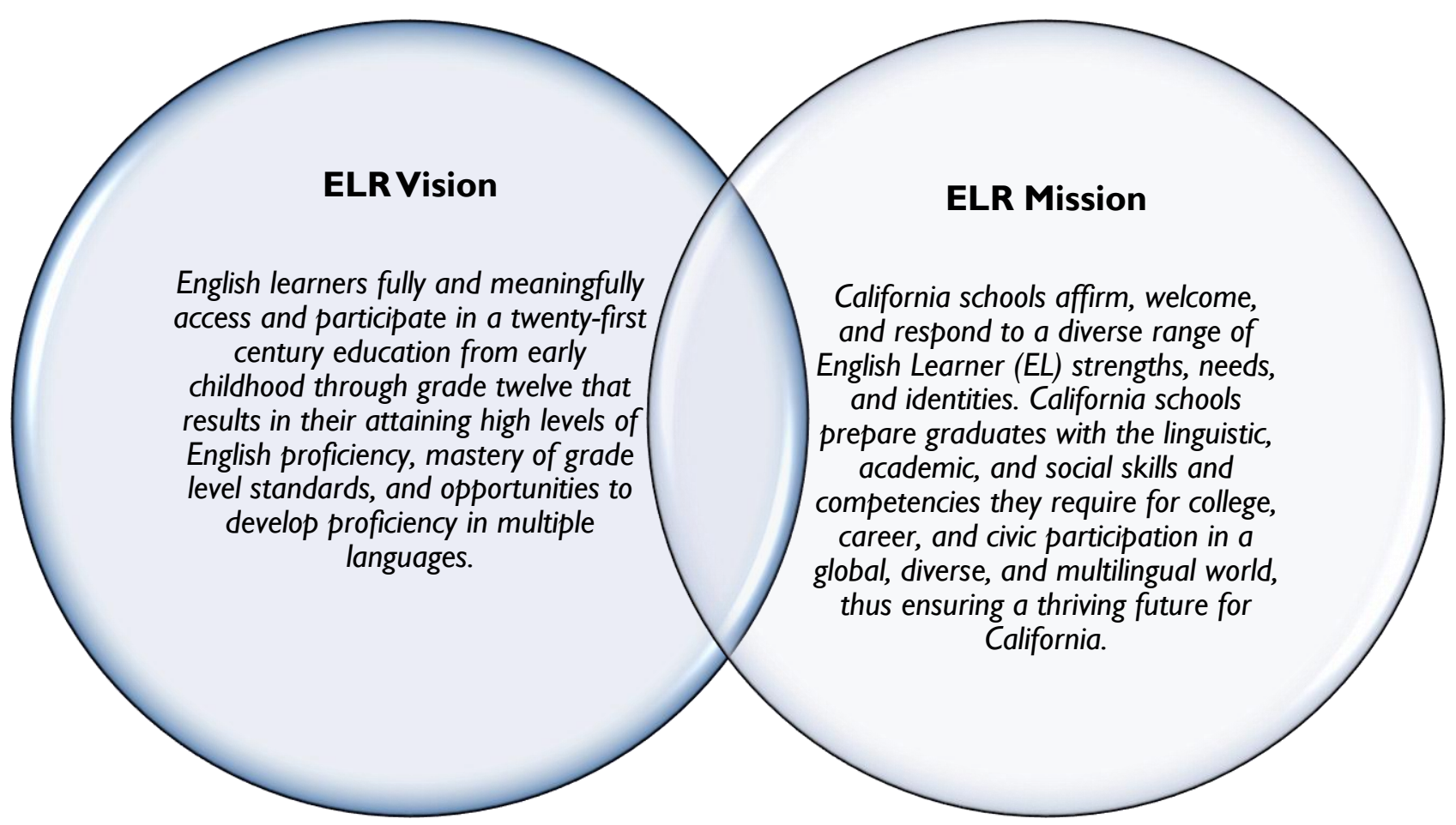

Tool \#I A. Outcomes

After reflecting on your LEA's existing mission and vision, you and your team will:

- Identify the alignment between the existing LEA's vision for English learners, the existing EL Master Plan (if available), and the CA English Learner Roadmap policy.

- Identify action steps to develop or refine your LEA's vision for English Learner education. 


\section{Tool \#IA: Review LEA Vision and Mission for EL Education}

\section{Preparation}

Obtain these materials in advance of your team meeting:

- LEA vision and mission statements

- Existing EL Master Plan (if available)
Process

\section{Recommended steps:}

- Review the existing LEA vision and mission statements to identify the degree to which they communicate the LEA's view on their EL's education.

- Review the existing EL Master Plan (if available) for alignment with the LEA vision and mission and the CA English Learner Roadmap policy.

\section{Guiding Questions for Reflection}

I. Do our vision and mission statements communicate the view of ELs' languages and cultures as assets?

- If yes, are there missing elements? How can these be more aligned with the CA EL Roadmap policy?

- If not, what would be important to communicate in our EL Master Plan that extends our LEA's mission and vision statement and aligns with the CA EL Roadmap policy?

2. In your opinion, how has the existing LEA's vision and mission affected EL education in your context?

3. What process do you recommend to ensure the EL Master Plan aligns to the LEA vision and mission that views language and culture as assets?

\section{Identify Next Steps:}

What needs to happen? Who will lead the effort? When will this occur? 


\section{TOOL \# IB. IDENTIFY STAKEHOLDERS}

Throughout the EL Master Plan development process, you will engage different teams. Your EL Master Plan Leadership team may be comprised of a Director or Coordinator of Federal and State Programs, Multilingual Education, or other LEA central office administrator. You will also need a team of lead writers and representative stakeholders who will participate in advisory sessions and convenings during the iterative EL Master Plan development processes.

\section{Tool \# I B. Outcomes}

After reflecting on your LEA's existing mission and vision, you and your team will:

- Identify key leaders and stakeholders essential to successfully develop an EL Master Plan.

\section{Tool \#I B: Identify Stakeholders}

\section{Preparation}

Acquire LEA organizational charts, staff rosters, and family committees with EL expertise/focus:

- Key stakeholders across LEA central office departments

- Key stakeholders at school site level

- Key community stakeholders

\section{Process}

\section{Recommended steps:}

- Identify stakeholders with the expertise to advise and provide input during the development of the EL Master Plan

- Review criteria

- Identify staff who will be lead writers for the EL Master Plan

\section{Guiding Questions for Reflection}

I. What existing leadership team(s) currently focus on English Learner programs?

- How can these teams' expertise be leveraged for the development of the English Learner Master Plan project?

What other teams may be necessary?

2. How will key staff members and stakeholders be identified? What selection criteria will be used?

- Review the sample stakeholder categories and criteria chart below. What roles might you add to this chart? How might you revise or expand the criteria? 
Identify Next Steps (e.g., How will each team contribute to the development and implementation of the EL Master Plan? Who will contact them and when? What is the timeline to have everyone onboard?):

Tool \#IB. Identify Stakeholders - Sample Stakeholder Categories and Criteria

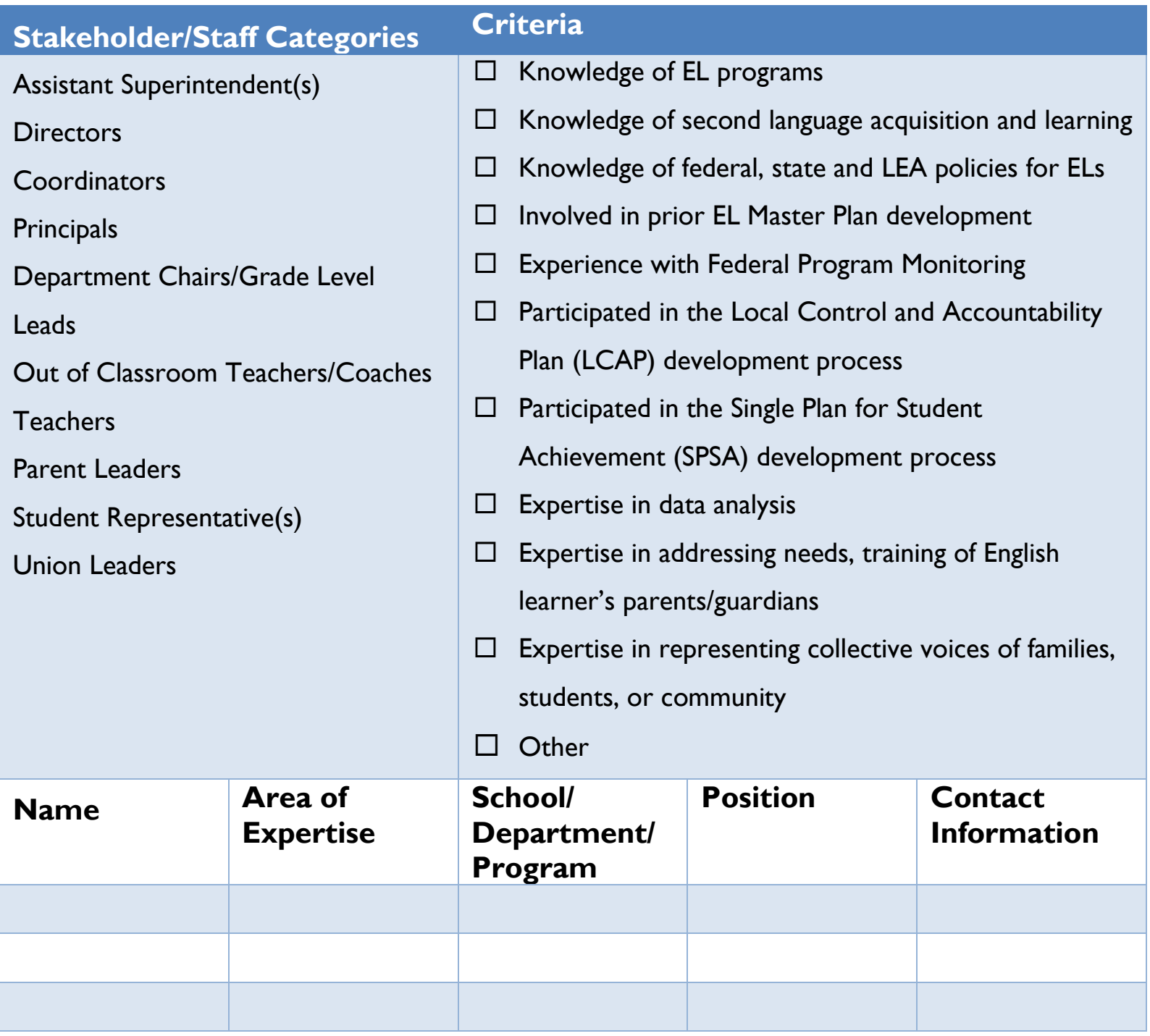




\section{TOOL \#IC. BUILD CONTEXT}

Your LEA has a history of providing programs and services for English learners. As you begin your EL Master Plan development/refinement, it will be important for you and your leadership team to "take stock" of all existing documents, policies, programs, and services related to English learners.

\section{Tool \#IC Outcomes}

After reflecting on your LEA's existing programs and services for ELs, you and your team will identify next steps for refining descriptions of:

- EL policies, programs, and services aligned with the CA English Learner Roadmap policy.

\section{Tool \#| C: Build Context}

\section{Preparation}

Obtain these materials in advance of your team meeting:

- EL program descriptions, resource materials

- Current EL Master Plan (if available)

\section{Process}

\section{Recommended steps:}

- List all EL programs and services offered.

- Identify elements of existing EL Master Plan (if available) to build from.

- Reflect on successes/challenges.

\section{Guiding Questions for Reflection}

I. List the programs, services, resources provided to schools aimed at supporting ELs.

- List program options (transitional, dual, structured English immersion) offered and where they exist.

- List EL services offered. Does the list of services provide evidence of clarity between base and supplemental services?

- List resources for ELs (e.g., partnerships, referral system, etc.)

2. Review your current EL Master Plan. How are programs and services described? What elements of your MP can you build from?

3. What have been successes in serving your English Learner students? What are the greatest challenges?

\section{Identify Next Steps:}

What programs and services need to be more clearly defined? How can these be aligned with the CA English Learner Roadmap? What additional inquiry is needed? 


\section{STEP 2: ENGAGE IN INQUIRY, MANAGE PROJECT, AND LAUNCH DEVELOPMENT}

Once the LEA has had the opportunity to reflect and organize, it is ready to consider how to best manage the EL Master Plan project development. These considerations include the analysis of data, engagement in inquiry to propel the work, setting timelines, and identifying tasks that will lead to an efficacious project.

The Inquiry and Management Tool (Tool \#2) is used after an LEA team has reflected on readiness to begin the EL Master Plan development process. The purpose of Tool \#2 is to help LEA leadership teams consider project management, collaborative data inquiry, and other organizational steps necessary to effectively launch EL Master Plan development and writing processes. It helps a team set the course for effective and efficient processes to develop an EL Master Plan.

Prior to beginning the EL Master Plan writing process, consider the areas with intentionality of the design, process, and progress throughout the development and writing processes. This tool delineates nine areas essential to EL Master Plan project management. These include:

- Communication - What will be communicated? To whom? How? When?

- Stakeholders - Who will be involved in the process? What roles will various stakeholders play in the development of the plan?

- Tasks - What tasks will need to be accomplished in order to develop the plan?

- Timeline - How will you design your overall project management timeline? When will specific tasks be due?

- Mandates/Guidelines - How will federal and state laws, or mandates be included in the plan? How will the LEA's existing strategic plan, policies and guidelines be addressed?

- Research - How will current research regarding English learners guide the EL Master Plan?

- Resources - What resources exist in the LEA that will be capitalized upon? What resources will be included or needed to implement a plan that provides equity for English learners?

- Data Inquiry - What data needs to be gathered and analyzed that will inform the plan writing? What questions might we want to answer, based on these analyses?

- Processes - What processes will be utilized to develop the plan? Gather information/data? 
Tool \#2 supports overall project management to identify status updates and promote continuous progress toward completion. We include a 3-point scale that signals planning phases:

\section{IIII Not Started (Phase I) \\ 29. Discussed with Leadership (Phase 2) \\ Discussion with Stakeholders (Phase 3).}

\section{Figure 6 - Tool \#2 Outcomes}

Using Tool \#2 affords LEA lead teams the opportunity to identify:

- the LEA's groundwork needed for writing the English Learner Master Plan

- recurring actions and next steps towards progress in each planning and development area, such as communication or stakeholder engagement
LEA leadership teams can use this tool at various phases of the EL Master Plan development processes to celebrate meeting important benchmarks and to identify areas that need additional support for project advancement or improvement (see Figure 6 for outcomes). Additionally, the descriptors for each of the phases elucidate engagement expectations for LEA administration, leadership teams, and various stakeholder groups.

\section{CONSIDERATIONS FOR INQUIRY AND PROJECT MANAGEMENT}

To support LEA leadership teams efficient use of Tool \#2, we offer key considerations for the areas essential to inquiry and project management. LEA teams may decide to assign these management tasks to a lead project manager, or to a team within the English Learner department or division.

\section{Communication and Stakeholders}

Once a leadership team is identified, decisions about communication processes, frequency, and follow up action steps need to be finalized. For example, the project manager can commit to providing quarterly updates at the LEA board meetings, monthly updates at LEA-wide director and site-administrator meetings, and regular

"Good communication is the bridge between confusion and clarity."

-Nat Turner 
updates at community/parent meetings such as the District English Learner Advisory

Committee (DELAC). Additionally, the leadership team should finalize roles and responsibilities for EL Master Plan development collaborators. Tool \#IB: Identify Stakeholders provides recommended roles and criteria for a stakeholder advisory committee; LEAs also will need to identify a lead writing team and potential subcommittees. Sample responsibilities for a lead writer may include:

- Review input from the EL Master Plan Advisory (stakeholder) Committee and make recommendations based on the input

- Provide input on the content of the EL Master Plan

- Co-write chapters/components of the EL Master Plan

- Review and advise on drafts of EL Master Plan

- Assist in the development of policy and program statements related to aspects of the EL Master Plan

- Convene sub-committees to solicit feedback on drafts of the EL Master Plan

Subcommittees can be recruited from existing EL focus groups such as the Language Appraisal Team, EL teacher/coach/coordinator leads, and/or cross-department collaborators (directors, coordinators, or teacher leads) who oversee accountability, professional learning, technology, special education or other relevant areas.

\section{Mandates and Guidelines}

As an LEA team develops the EL Master Plan, it will be important to consult with district or county leaders to ensure adherence to federal and state legal mandates for English Learner education. At the federal level, a joint U.S. Department of Justice and U. S. Department of Education 2015 Dear Colleague letter reiterated:

"The Departments are issuing the enclosed joint guidance to assist SEAs, school districts, and all public schools in meeting their legal obligations to ensure that EL students can participate meaningfully and equally in educational programs and services. This guidance provides an outline of the legal obligations of SEAs and school districts to EL students under the civil rights laws." (page 2)

The guidance focuses on the responsibilities of school districts and establishes that State Education Agencies (SEAs) also have legal obligations toward EL students and their parents. SEAs and school districts are strongly encouraged to reevaluate policies and practices related to their EL programs to ensure compliance and improve access to educational programs and services. Resources are available at the U.S. Department of Education's website, including the Office of English Language Acquisition English Learner Toolkit.

At the state level, the California Department of Education helps to support English learner programs in California by providing resources for local LEA programs; these supports are 
detailed in a dedicated webpage for English learners and include the California English Learner Roadmap policy. Additionally, the Technical Assistance and Monitoring Office (TAMO) provides monitoring and technical assistance to local educational agencies (LEAs). An English Learner program instrument comprises federal and state requirements and requests for evidence that may be used to demonstrate compliance during the Federal Program Monitoring (FPM) process.

\section{Resources and Research}

As LEA teams engage in the EL Master Plan development, it will be important to identify existing district documents needed to support its development. An example of this might include Designated English Language Development guidelines stating mandated number of daily minutes, grouping considerations, materials, and other important information. Another source document may provide an overview of the EL assessments, benchmarks, and expectations for English language proficiency and academic progress. For some, your LEA may have recently undergone an online or onsite Federal Program Monitoring for Title III, and it will be important to review the documentation and outcomes of this. We recommend that teams take time to gather and organize these documents so that they can be reviewed, revised, and included in the EL Master Plan. Below is a chart to help identify, organize, and prioritize action steps for reviewing documents and resources.

\begin{tabular}{|l|l|l|}
\hline $\begin{array}{l}\text { Document or Resource } \\
\text { (district reports, plans, } \\
\text { guidance) }\end{array}$ & Why is it needed? & $\begin{array}{l}\text { Person Responsible for } \\
\text { reviewing and Due } \\
\text { Date }\end{array}$ \\
\hline & & \\
\hline & & \\
\hline & & \\
\hline
\end{tabular}

A critical review of the existing documents will uncover questions and potential gaps in information. As such, it will be important to assign a team to locate current, relevant research that can inform your stakeholders and lead writers in the EL Master Plan development processes. Appendices I -5 provide a list of resources to support this step.

\section{Inquiry}

School districts throughout California and the nation have policies, guidelines, and/or existing EL Master Plans that are intended to serve English learners to not only develop their English language proficiency, but to also develop $21^{\text {st }}$ century skills that contribute positively to diverse local and global communities. Data provides us a means to gauge whether these policies, 
practices and modus operandum are meeting the intended outcomes ${ }^{9}$. Examining varied quantitative and qualitative data sources in the district can serve to:

- Acquire a wholistic view of how ELs are performing within and across schools

- Explore causal factors that contribute to ELs' performance or outcomes

- Reflect on what might need to be changed, maintained, added or included in policies, practices, or strategies that will contribute to positive outcomes for English learners

- Inform the content development/refinement of an EL Master Plan

As LEA teams engage in data inquiry processes, we recommend obtaining information from data sources such as ( $I$ ) district and state level summative assessments for language arts and mathematics; (2) district and state level summative assessments for language proficiency progress; (3) college and career course enrollment patterns; (4) leader, teacher, family, and student surveys; and (5) classroom observations or instructional walks. All data sources should include disaggregated data specific to current and former English learners, with an emphasis on types of ELs to the extent possible (e.g., Long Term English learners, newcomer students, etc.). Figure 5 suggests an inquiry approach that can serve to guide data dialogues while simultaneously documenting stakeholder input and reflections that will inform the content of the EL Master Plan.

Figure 5. EL-focused Inquiry: Guided Dialogue

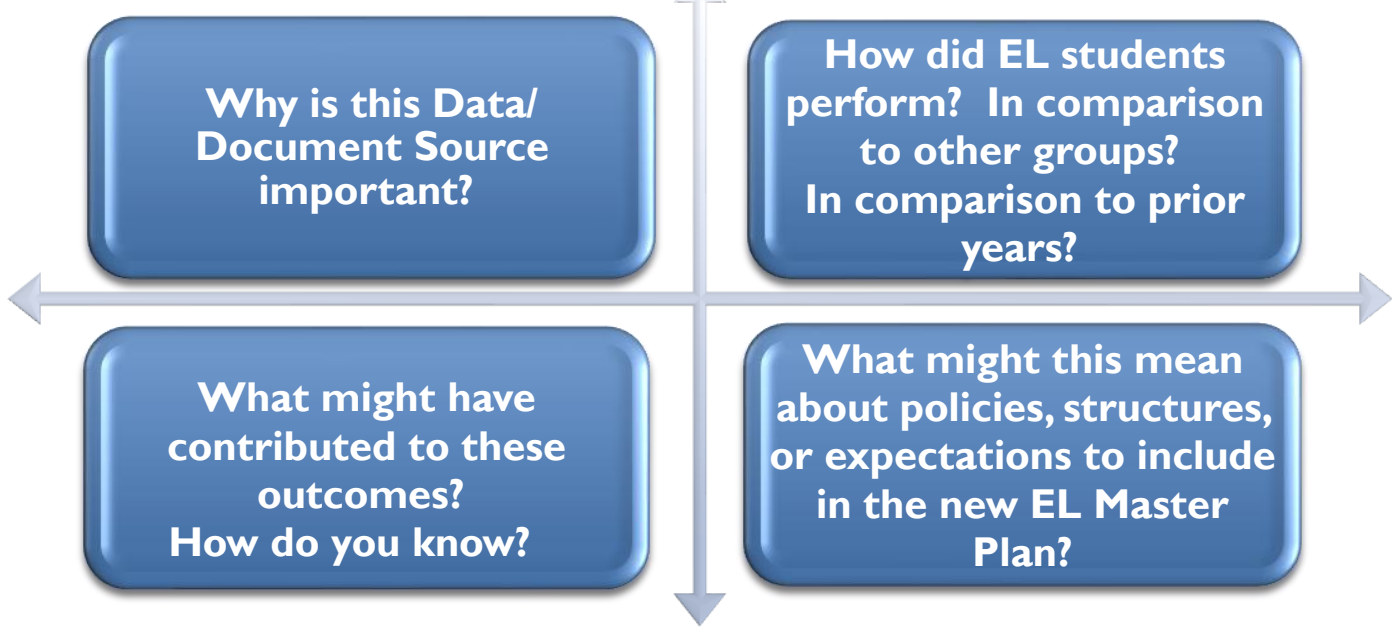

${ }^{9}$ Wellman, B. \& Lipton, L. (2017). Data-Driven Dialogue: A Facilitators's Guide to Collaborative Inquiry (2nd ed.). Miravia. 
Tool \#2: Inquiry and Management provides the user a convenient method of ensuring that the elements integral to co-constructed inquiry and inclusive project management are thoroughly and consistently addressed during the EL Master Plan development timeframe. As stated previously, although this tool is identified as "Step 2" in the development process, it is used for the duration of the project as a reference for the EL Master Plan lead team to document progress, record next steps, and report key project milestones to all stakeholders.

This tool will help LEA leadership teams surface areas of inquiry that affect the writing of the EL Master Plan and support project launch and management. 


\begin{tabular}{|c|c|c|c|}
\hline \multicolumn{4}{|l|}{$\frac{\text { Outcomes }}{\text { Using this to }}$} \\
\hline $\begin{array}{l}\text { Areas for } \\
\text { Inquiry } \& \\
\text { Management }\end{array}$ & Not Started & Discussed with Leadership & In Discussion with \\
\hline Communication & $\begin{array}{l}\text { Superintendent and } \\
\text { cabinet have not } \\
\text { communicated the need } \\
\text { for an EL Master Plan, nor } \\
\text { the LEA's intentions in } \\
\text { writing one. }\end{array}$ & $\begin{array}{l}\square \text { The superintendent, the cabinet, } \\
\text { as well as department leads for } \\
\text { instruction, EL, compliance, } \\
\text { family discuss \& establish the } \\
\text { rationale for the plan. }\end{array}$ & $\begin{array}{l}\square \text { The rationale for creating/revising the } \\
\text { LEA's EL Master Plan is communicated } \\
\text { to stakeholders in various ways. }\end{array}$ \\
\hline Stakeholders & $\begin{array}{l}\square \text { Stakeholders engaged in } \\
\text { the process have not been } \\
\text { identified. }\end{array}$ & $\begin{array}{l}\square \text { LEA leaders in charge of the } \\
\text { development of the plan are } \\
\text { identified. } \\
\square \text { Stakeholders engaged in the plan } \\
\text { and their role in the process are } \\
\text { identified. }\end{array}$ & $\begin{array}{l}\square \text { Stakeholders engaged in the } \\
\text { development process clarify their roles } \\
\text { and responsibilities. } \\
\square \text { Roles and responsibilities might } \\
\text { include: writers, editors, data analysts, } \\
\text { etc. }\end{array}$ \\
\hline Tasks & $\begin{array}{l}\square \text { Necessary tasks to } \\
\text { develop the plan have not } \\
\text { been identified. }\end{array}$ & $\begin{array}{l}\square \text { Necessary tasks to develop the } \\
\text { plan are identified by leadership. }\end{array}$ & $\begin{array}{l}\square \text { Committees for specific tasks/plan } \\
\text { components are identified. } \\
\square \text { Main writer(s) for each section are } \\
\text { identified. } \\
\square \text { Criteria for each section of the plan is } \\
\text { developed/ reviewed. }\end{array}$ \\
\hline 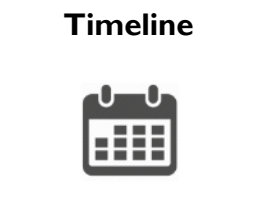 & $\begin{array}{l}\square \text { A timeline for the plan } \\
\text { and the completion of } \\
\text { specific tasks has not been } \\
\text { established. }\end{array}$ & $\begin{array}{l}\square \text { The timeline for developing the } \\
\text { plan and completion of specific } \\
\text { tasks is established. } \\
\square \text { Check-ins for progress are } \\
\text { scheduled. }\end{array}$ & $\begin{array}{l}\square \text { Committees and writers complete } \\
\text { tasks according to timeline. } \\
\square \text { Check-ins take place according to } \\
\text { timeline. }\end{array}$ \\
\hline $\begin{array}{l}\text { Mandates/ } \\
\text { Guidelines }\end{array}$ & $\begin{array}{l}\square \text { Federal, state, county and } \\
\text { LEA guidelines germane to } \\
\text { the writing have not been } \\
\text { identified/ gathered/ } \\
\text { reviewed. }\end{array}$ & $\begin{array}{l}\square \text { Leads gather and review federal, } \\
\text { state, county and LEA guidelines } \\
\text { germane to the writing. }\end{array}$ & $\begin{array}{l}\square \text { Identified committees review: existing } \\
\text { LEA plans, policies, guidelines, and } \\
\text { LEA/school site practices to determine } \\
\text { whether to: include in the plan, drop } \\
\text { or revise based on data/evidence. }\end{array}$ \\
\hline Research & $\begin{array}{l}\square \text { Research that supports } \\
\text { equity, and pedagogical } \\
\text { practices for English } \\
\text { learners has not been } \\
\text { identified/ gathered/ } \\
\text { reviewed. }\end{array}$ & $\begin{array}{l}\square \text { Leads gather and review } \\
\text { research that supports equity, } \\
\text { and pedagogical practices for } \\
\text { English learners. }\end{array}$ & $\begin{array}{l}\square \text { Purposefully designed committees } \\
\text { share relevant research and } \\
\text { recommend current relevant research } \\
\text { to include specific components. }\end{array}$ \\
\hline
\end{tabular}




\begin{tabular}{|c|c|c|c|}
\hline $\begin{array}{l}\text { Areas for } \\
\text { Inquiry \& } \\
\text { Management }\end{array}$ & Not Started & Discussed with Leadership & $\begin{array}{l}\text { In Discussion with } \\
\text { Stakeholders }\end{array}$ \\
\hline Resources & $\begin{array}{l}\square \text { Existing plans have not } \\
\text { been reviewed. }\end{array}$ & $\begin{array}{l}\square \text { Leads gather and review existing } \\
\text { LEA plans, policies and } \\
\text { guidelines. }\end{array}$ & $\begin{array}{l}\square \text { Resources that will be included in the } \\
\text { plan, or that are needed for } \\
\text { implementation are shared with the } \\
\text { writers and members of EL Master } \\
\text { Plan development group. }\end{array}$ \\
\hline Data Inquiry & $\begin{array}{l}\square \text { No rationale for data } \\
\text { gathering has been } \\
\text { established. } \\
\\
\text { Student data (typologies, } \\
\text { achievement, English } \\
\text { language development } \\
\text { progress, historical or } \\
\text { programmatic data, etc.) } \\
\text { that will affect the writing } \\
\text { have not been identified. } \\
\\
\square \text { Comparison data to be } \\
\text { analyzed: school to school } \\
\text { comparison by subgroups, } \\
\text { school to school by } \\
\text { program, student to LEA } \\
\text { comparison, within school } \\
\text { data comparison has not } \\
\text { been identified. } \\
\\
\square \text { Surveys (stakeholder) to } \\
\text { inform the ELMP writing } \\
\text { have not been identified } \\
\text { or do not address EL } \\
\text { demographic or } \\
\text { programmatic areas. } \\
\square \text { Qualitative data, aside } \\
\text { from surveys, that will } \\
\text { inform the writing has not } \\
\text { been identified (e.g., } \\
\text { portfolios with rubric } \\
\text { graded writing, case } \\
\text { studies, Language } \\
\text { Appraisal referral } \\
\text { schedules and data, etc.). } \\
\square \text { Personnel data related to } \\
\text { the number of qualified/ } \\
\text { certificated bilingual } \\
\text { teachers, } \\
\text { paraprofessionals, has not } \\
\text { been gathered or } \\
\text { identified. }\end{array}$ & $\begin{array}{l}\square \text { Rationale for data gathering and } \\
\text { how each data set contributes to } \\
\text { the writing of a comprehensive } \\
\text { plan has been established. } \\
\square \text { Student data (typologies, } \\
\text { achievement, English language } \\
\text { development progress, historical } \\
\text { or programmatic data, etc.) that } \\
\text { will affect the writing have been } \\
\text { identified. } \\
\square \text { Comparison data (school to } \\
\text { school comparison by subgroups, } \\
\text { school to school by program, } \\
\text { student to LEA comparison, } \\
\text { within school data comparison) } \\
\text { has been identified. } \\
\square \text { Surveys (stakeholder) to inform } \\
\text { the writing have been identified, } \\
\text { or drafted. } \\
\square \text { Qualitative system data, aside } \\
\text { from surveys, that will inform the } \\
\text { writing has been identified (e.g., } \\
\text { portfolios with rubric graded } \\
\text { writing, case studies, Language } \\
\text { Appraisal team schedules and } \\
\text { data, etc.). } \\
\square \text { Personnel data related to the } \\
\text { number of qualified/ certificated } \\
\text { bilingual teachers, } \\
\text { paraprofessionals, has been } \\
\text { gathered or identified. }\end{array}$ & $\begin{array}{l}\square \text { Student data has been disaggregated } \\
\text { and analyzed to identify: existing EL } \\
\text { student trends, successes, challenges } \\
\text { and possible areas of inquiry. } \\
\square \text { Comparison data has been analyzed to } \\
\text { identify: existing EL student trends, } \\
\text { successes, challenges and possible } \\
\text { areas of inquiry. } \\
\square \text { Surveys (stakeholder) to inform the } \\
\text { writing have been analyzed to identify } \\
\text { perceived successes, challenges and } \\
\text { possible areas of inquiry. } \\
\square \text { Qualitative system data to inform the } \\
\text { writing has been analyzed to identify } \\
\text { trends, successes, challenges and } \\
\text { possible areas of inquiry. } \\
\square \text { Relationship among data sets has been } \\
\text { compiled to identify: EL trends, } \\
\text { successes, challenges, areas of inquiry } \\
\text { and areas to address in the ELMP. } \\
\square \text { Results of data analysis are prepared } \\
\text { and communicated to writing teams } \\
\text { responsible for specific areas. }\end{array}$ \\
\hline $\begin{array}{l}\text { Processes } \\
\text { Getes }\end{array}$ & $\begin{array}{l}\square \text { Processes to: gather } \\
\text { voices from stakeholders, } \\
\text { analyze data, develop the } \\
\text { plan, gather feedback, } \\
\text { revise, etc. have not been } \\
\text { established. }\end{array}$ & $\begin{array}{l}\square \text { Processes to: gather voices from } \\
\text { stakeholders, analyze data, } \\
\text { develop the plan, gather } \\
\text { feedback, revise, etc. are } \\
\text { established. }\end{array}$ & $\begin{array}{l}\square \text { Processes on how data and surveys } \\
\text { will be analyzed and communicated are } \\
\text { established. Timeline and steps in } \\
\text { revision/feedback are reviewed. }\end{array}$ \\
\hline
\end{tabular}




\section{STEP 3: CONDUCT ITERATIVE WRITING AND FEEDBACK SESSIONS}

TOOL \#3: CHAPTER ANALYSIS, REFLECTION AND EVALUATION (CARE)

Writing the English Learner Master Plan is an iterative process that is supported when clear criteria for content are organized, attended to, and communicated. We use the acronym CARE (Chapter Analysis, Reflection and Evaluation) to describe the writing and feedback cycles that engage and support writers and the writing team to make timely revisions and adjustments toward completing a final draft of their plan.

A complement to our inquiry and management tool (see Tool \#2 above), Tool \#3: Chapter Analysis Reflection and Evaluation (CARE) Tool identifies ten research-based components that also correspond to legally monitored compliance items. It may be that LEAs decide to combine several components into one chapter, or create additional chapters depending on the preferred organization of the EL Master Plan in their LEA. As such, we use the term component and chapter interchangeably. Each component of the CARE Tool has content criteria descriptors to reference when developing a specific chapter of the EL Master Plan.

"Writing is thinking. To write well is to think clearly."

-David McCullough

We provide each CARE Tool component as a stand-alone document so that lead writers or teams may focus on the chapter they are responsible for without distractors. This allows various writing teams to work simultaneously, with a focus on their chapter and an awareness of criteria for other chapters. Each writing team can note strengths and challenges, based on criteria feedback and identify next-step actions. Likewise, each writing team will have information to communicate to the leadership team and other stakeholders.

The CARE Tool is intended to be used throughout the process of writing the EL Master Plan. It supports those responsible for the writing of each component to:

- Address all elements for that chapter.

- Determine next steps in revising the writing to include missing elements.

This tool also serves teams and stakeholders involved in plan development, but not responsible for the writing of a specific chapter to provide feedback and recommendations. 
Another intended use of the CARE Tool is to maintain communication about the EL Master Plan progress, including recommendations and revisions as it is being developed. Transparency throughout the process plays a key role in building buy-in and readiness to implement the EL Master Plan. Figure 7 highlights Tool \#3 user outcomes. Each of the ten components in the CARE Tool are presented separately (see Figure 8), with a rationale for its inclusion in the EL Master Plan and a range of recommended content. Each CARE component specifies content criteria that may be used as an outline for writers. Additionally, the CARE Tool provides writing criteria to support reflection, feedback, and revision as needed. To facilitate communication, each CARE Tool component also includes a structure to document considerations and next steps for providing stakeholders timely updates as well as seeking input.

Figure 8. Tool \#3: Chapter Analysis Reflection and Evaluation (CARE) Components
COMPONENT \#6: ENGLISH LANGUAGE DEVELOPMENT

Di:

COMPONENT \#8: FAMILY-SCHOOL PARTNERSHIPS

COMPONENT \#9: ASSESSMENT \& STUDENT MONITORING

COMPONENT \#10: PROGRAM MONITORING \& EVALUATION 


\section{COMPONENT \#I - COMMITMENT AND PURPOSE}

Rationale: An English Learner Master Plan provides clarity, direction and coherence to an LEA educating ELs. The commitment and purpose component serves to provide the system with clear rationale and guidance for: I) who is being serviced, 2) what those services are, 3) why they are provided, 4) how the EL Master Plan serves to ensure equity for English learners ${ }^{10}$, and 5) assurances for adherence to federal and state mandates ${ }^{11}$.

\section{CONTENT OVERVIEW}

- Rationale for the English Learner Master Plan

- Superintendent's message

- LEA's vision, mission, values and beliefs inclusive of English learners

- LEA's overview of its diverse populations, including English learners by typologies and programs (i.e., Dual Language)

- Federal and state requirements for services to English learners

The commitment and purpose component of the EL Master Plan is aligned with the following principles of the California EL Roadmap (ELR). See Table I for alignment to ELR elements.

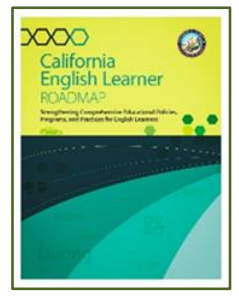

$\checkmark$ Principle I: Assets-Oriented and Needs-Responsive Schools

$\checkmark$ Principle 2: Intellectual Quality of Instruction and Meaningful Access

$\checkmark$ Principle 3: System Conditions that Support Effectiveness

$\checkmark$ Principle 4: Alignment and Articulation within and Across Systems

The following Federal Program Monitoring items are addressed:

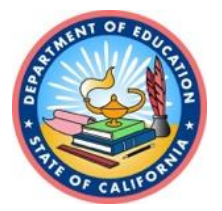

There is a stated intent to adhere to federal and state legal requirements

across Federal Program Monitoring Items (see content criteria in Component \#I below).

\footnotetext{
${ }^{10}$ Olsen, L., \& Maxwell-Jolly, J. (2018). English learners in focus: The English Learner Roadmap: Providing direction for English Learner success. California School Boards Association. https://www.csba.org/GovernanceAndPolicyResources/ /media/CSBA/Files/GovernanceResources/ GovernanceBriefs/201802EnglishLearnerRoadmap.ashx

" U.S. Department of Justice and U. S. Department of Education 2015 Dear Colleague Letter;

Cook-Harvey, C. M., Darling-Hammond, L., Lam, L., Mercer, C., \& Roc, M. (2016). Equity and ESSA: Leveraging educational opportunity through the Every Student Succeeds Act. Learning Policy Institute. https://learningpolicyinstitute.org/product/equity-essa-report
} 


\begin{tabular}{|c|c|c|}
\hline \multirow[b]{2}{*}{ CONTENT CRITERIA } & OMMITMENT A & \multirow[b]{2}{*}{ Next Steps } \\
\hline & $\begin{array}{l}\text { Evidence \& Notes } \\
\text { Date }\end{array}$ & \\
\hline $\begin{array}{l}\text { There is a statement from the } \\
\text { superintendent highlighting their } \\
\text { commitment to English learners, the } \\
\text { implementation of the English learner } \\
\text { plan and alignment to federal, state and } \\
\text { district initiatives. }\end{array}$ & & \\
\hline $\begin{array}{l}\text { There is a description of the district: } \\
\text { number of schools by category } \\
\text { (elementary, span, etc.), number of } \\
\text { students, population breakdown (\% of } \\
\text { ELs, SWD, FY, HY, etc.). }\end{array}$ & & \\
\hline $\begin{array}{l}\text { The rationale for the plan is clearly } \\
\text { articulated. }\end{array}$ & & \\
\hline $\begin{array}{l}\text { There are statements about the } \\
\text { district's vision, mission, beliefs and } \\
\text { values regarding English learners, } \\
\text { equity, and opportunity. }\end{array}$ & & \\
\hline $\begin{array}{l}\text { There is reference to policy, initiatives, } \\
\text { and legal requirements for educating } \\
\text { ELs. (e.g. California English Learner } \\
\text { Roadmap Policy, Local Control and } \\
\text { Accountability Plan (LCAP), etc. }\end{array}$ & & \\
\hline $\begin{array}{l}\text { The development process is described } \\
\text { and stakeholders involved in the } \\
\text { process are acknowledged and } \\
\text { thanked. }\end{array}$ & & \\
\hline
\end{tabular}




\begin{tabular}{|c|c|c|}
\hline \multicolumn{3}{|c|}{$\begin{array}{l}\text { C.A.R.E. Tool } \\
\text { COMPONENT \#I- COMMITMENT AND PURPOSE }\end{array}$} \\
\hline \multicolumn{2}{|c|}{ WRITING CRITERIA } & \multirow[t]{2}{*}{ Notes and Action Steps } \\
\hline & $\begin{array}{l}\text { Revise for: } \\
\text { I) meaning } \\
\text { 2) word choice } \\
\text { 3) coherence within and across } \\
\text { district education plans } \\
\text { 4) connectedness within this } \\
\text { chapter }\end{array}$ & \\
\hline $\begin{array}{c}\text { Mandates \& } \\
\text { Guidelines }\end{array}$ & $\begin{array}{l}\text { Check for inclusion of those } \\
\text { that apply: } \\
\text { I) adherence to current federal } \\
\text { and state mandates } \\
\text { 2) district policies and practices } \\
\text { with stated } \\
\text { rationale/expectations }\end{array}$ & \\
\hline Research & $\begin{array}{l}\text { Confirm that research cited is: } \\
\text { 1) recent } \\
\text { 2) relevant } \\
\text { 3) accurately cited } \\
\text { 4) logical }\end{array}$ & \\
\hline Resources & $\begin{array}{l}\text { Check that relevant resources } \\
\text { are accessible to the user via } \\
\text { hyperlinks, or as an appendix. } \\
\text { Examples: } \\
\text { 1) other district plans, support } \\
\text { offices information, etc. } \\
\text { 2) federal, state, local agencies' } \\
\text { resources } \\
\text { 3) assessment guidelines, parent } \\
\text { communication letters, } \\
\text { Designated ELD policies }\end{array}$ & \\
\hline \multicolumn{2}{|c|}{ COMMUNICATION } & $\begin{array}{l}\text { Notes and Action Steps } \\
\text { What needs to be communicated and to whom? }\end{array}$ \\
\hline $\begin{array}{c}\text { District } \\
\text { Leadership \& } \\
\text { Stakeholders }\end{array}$ & $\begin{array}{l}\text { Status of plan revision phases is } \\
\text { communicated to LEA leadership. }\end{array}$ & \\
\hline Committees & $\begin{array}{l}\text { Committees or other lead } \\
\text { writers are kept abreast of the } \\
\text { revision phases and how their } \\
\text { feedback affected the revisions. }\end{array}$ & \\
\hline
\end{tabular}




\section{COMPONENT \#2 - RESPONDING TO DIVERSE LEARNERS}

Rationale: A welcoming and affirming educational system ensures that Multilingual/English learners and their families ${ }^{12}$ are introduced to a system with clearly articulated and consistent practices for initial assessment ${ }^{13}$ and program placement, including considerations for English learners with Disabilities ${ }^{14}$. These processes include multilingual communication with parents and/or guardians regarding initial assessment outcomes, program options, and pathways to biliteracy and reclassification ${ }^{15}$ as essential facets of college and career readiness.

\section{CONTENT OVERVIEW}

- Initial Identification Assessment Criteria

- Initial Identification Assessment Tool and Procedures

- Primary Language Assessment/Transcript Review

- Parental rights, notification, Program Options and Selection Processes

- Reclassification Criteria and Processes

- Considerations for Diverse Learners, including dually-identified students

The Responding to Diverse Learners' component is aligned with the following principles of the California EL Roadmap (ELR). See Table I for alignment to ELR elements.

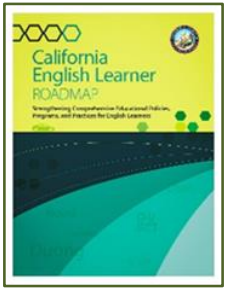

Principle I: Assets Oriented and Needs Responsive Schools

$\checkmark$ Principle 2: Intellectual Quality of Instruction and Meaningful Access

$\checkmark$ Principle 4: Alignment and Articulation within and Across Systems

The following Federal Program Monitoring items are addressed:

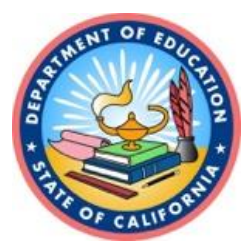

II. Governance and Administration

EL 03: EL Identification and Assessment $(3.0$ - 3.6)

IV. Standards, Assessment, and Accountability

EL 10: Reclassification (10.0-10.3)

\footnotetext{
12 Faulkner-Bond, M., Spycher, P., Olsen, L. \& Gandara, P. (2020). The Power and Promise of California's Multilingual Learners. In California Department of Education, Improving Education for Multilingual and English Learner Students: Research to Practice (pp. 27-62).

${ }^{13}$ Bailey, A. L., \& Carroll, P. E. (2015). Assessment of English Language Learners in the era of new academic content standards. Review of Research in Education, 39(I), 253-294. https://doi.org/I0.3I02/009I732XI4556074

${ }^{14}$ California Department of Education (2019). California Practitioners' Guide for Educating English learners with Disabilities. https://www.cde.ca.gov/sp/se/ac/documents/ab2785guide.pdf

${ }^{15}$ Estrada, P., \& Wang, H. (2018). Making English Learner reclassification to fluent English proficient attainable or elusive: When meeting criteria is and is not enough. American Educational Research Journal, 55(2), 207-242. https://doi.org//0.3I02/000283/2 I7733543
} 


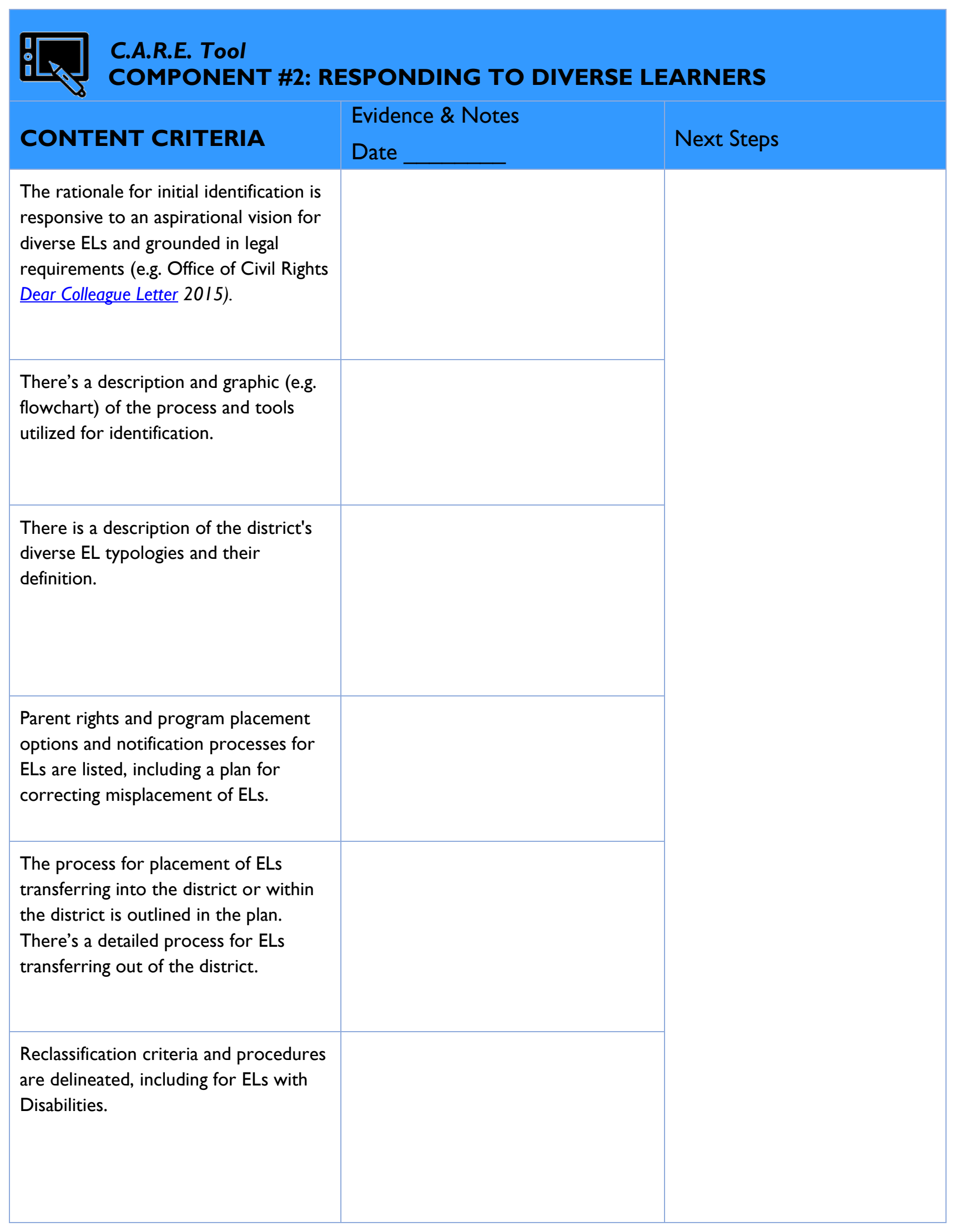




\begin{tabular}{|c|c|c|}
\hline \multicolumn{3}{|c|}{$\begin{array}{l}\text { C.A.R.E. Tool } \\
\text { COMPONENT \#2- RESPONDING TO DIVERSE LEARNERS }\end{array}$} \\
\hline \multicolumn{2}{|c|}{ WRITING CRITERIA } & Notes and Action Steps \\
\hline Revision & $\begin{array}{l}\text { Revise for: } \\
\text { I) meaning } \\
\text { 2) word choice } \\
\text { 3) coherence within and across } \\
\text { district education plans } \\
\text { 4) connectedness within this } \\
\text { chapter }\end{array}$ & \\
\hline $\begin{array}{l}\text { Mandates \& } \\
\text { Guidelines }\end{array}$ & $\begin{array}{l}\text { Check for inclusion of those } \\
\text { that apply: } \\
\text { I) adherence to current federal } \\
\text { and state mandates } \\
\text { 2) district policies and practices } \\
\text { with stated } \\
\text { rationale/expectations }\end{array}$ & \\
\hline Rese & $\begin{array}{l}\text { Confirm that research cited is: } \\
\text { 1) recent } \\
\text { 2) relevant } \\
\text { 3) accurately cited } \\
\text { 4) logical }\end{array}$ & \\
\hline Resources & $\begin{array}{l}\text { Check that relevant resources } \\
\text { are accessible to the user via } \\
\text { hyperlinks, or as an appendix. } \\
\text { Examples: } \\
\text { I) other district plans, support } \\
\text { offices information, etc. } \\
\text { 2) federal, state, local agencies' } \\
\text { resources } \\
\text { 3) assessment guidelines, parent } \\
\text { communication letters, } \\
\text { Designated ELD policies }\end{array}$ & \\
\hline \multicolumn{2}{|c|}{ COMMUNICATION } & $\begin{array}{l}\text { Notes and Action Steps } \\
\text { What needs to be communicated and to whom? }\end{array}$ \\
\hline $\begin{array}{c}\text { District } \\
\text { Leadership \& } \\
\text { Stakeholders }\end{array}$ & $\begin{array}{l}\text { Status of plan revision phases is } \\
\text { communicated to LEA leadership. }\end{array}$ & \\
\hline Committees & $\begin{array}{l}\text { Committees or other lead } \\
\text { writers are kept abreast of the } \\
\text { revision phases and how their } \\
\text { feedback affected the revisions. }\end{array}$ & \\
\hline
\end{tabular}




\section{COMPONENT \#3 - PROGRAM OPTIONS}

Rationale: A welcoming and affirming educational system provides research-based program options ${ }^{16}$ for students and their parents, recognizing that varied typologies of students have diverse needs ${ }^{17}$. The Global California 2030 initiative aspires to ensure students are ready to live and compete in a diverse, multilingual world; Dual language programs serve to prepare students to achieve this vision.

\section{CONTENT OVERVIEW}

- Description of programs being offered to English learners

- Benefits and alignment to typologies for each program being offered

- Dual language program models available for multilingual learners

- Expected progress through each program/modeled

- Parent rights, options and selection processes

The Program Options component is aligned with the following principles of the California EL Roadmap (ELR). See Table I for alignment to ELR elements.:

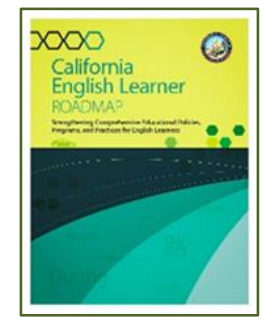

Principle I: Assets-Oriented and Needs-Responsive Schools

$\checkmark$ Principle 2: Intellectual Quality of Instruction and Meaningful Access

$\checkmark$ Principle 4: Alignment and Articulation within and Across Systems

The following Federal Program Monitoring items are addressed:

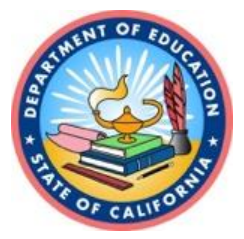

\section{Opportunity and Equal Educational Access}

EL 13: Language Acquisition Program Options and Parent Choice (13.1 - 13.5)

\footnotetext{
${ }^{16}$ Olsen, L., Martinez, M. Herrera, Carla B., \& Skibbins, H. (2020). In California Department of Education, Improving Education for Multilingual and English Learner Students: Research to Practice (Pp. II5-188).

${ }^{17}$ National Academies of Sciences, Engineering, and Medicine. (2017). Promoting the educational success of children and youth learning English: Promising futures. Author.
} 


\begin{tabular}{|c|c|c|}
\hline $\begin{array}{l}\text { C.A.R.E. Tool } \\
\text { COMPONENT \#3: }\end{array}$ & ROGRAM OPTIONS & \\
\hline CONTENT CRITERIA & $\begin{array}{l}\text { Evidence \& Notes } \\
\text { Date }\end{array}$ & Next Steps \\
\hline $\begin{array}{l}\text { All EL language acquisition programs } \\
\text { are described in detail. }\end{array}$ & & \\
\hline $\begin{array}{l}\text { The rationale for the offerings, } \\
\text { together with what benefits or services } \\
\text { each program affords students is } \\
\text { included. }\end{array}$ & & \\
\hline $\begin{array}{l}\text { For dual language/bilingual programs: } \\
\text { 1) models being offered are } \\
\text { described, } \\
\text { 2) rationale and intention of each } \\
\text { model are included, } \\
\text { 3) the classroom make up for each } \\
\text { model is included. }\end{array}$ & & \\
\hline $\begin{array}{l}\text { The plan includes student placement } \\
\text { criteria and staffing for each program } \\
\text { option. }\end{array}$ & & \\
\hline $\begin{array}{l}\text { Possible program options for the } \\
\text { diverse EL typologies are included in } \\
\text { the plan. }\end{array}$ & & \\
\hline $\begin{array}{l}\text { There is a description of the Seal of } \\
\text { Biliteracy and plan for biliteracy } \\
\text { pathway awards. }\end{array}$ & & \\
\hline
\end{tabular}




\begin{tabular}{|c|c|c|}
\hline \multicolumn{3}{|c|}{$\begin{array}{l}\text { C.A.R.E. Tool } \\
\text { COMPONENT \#3 - PROGRAM OPTIONS }\end{array}$} \\
\hline \multicolumn{2}{|c|}{ WRITING CRITERIA } & \multirow[t]{2}{*}{ Notes and Action Steps } \\
\hline Revision & $\begin{array}{l}\text { Revise for: } \\
\text { I) meaning } \\
\text { 2) word choice } \\
\text { 3) coherence within and across } \\
\text { district education plans } \\
\text { 4) connectedness within this } \\
\text { chapter }\end{array}$ & \\
\hline $\begin{array}{c}\text { Mandates \& } \\
\text { Guidelines }\end{array}$ & $\begin{array}{l}\text { Check for inclusion of those } \\
\text { that apply: } \\
\text { I) adherence to current federal } \\
\text { and state mandates } \\
\text { 2) district policies and practices } \\
\text { with stated } \\
\text { rationale/expectations }\end{array}$ & \\
\hline Resea & $\begin{array}{l}\text { Confirm that research cited is: } \\
\text { 1) recent } \\
\text { 2) relevant } \\
\text { 3) accurately cited } \\
\text { 4) logical }\end{array}$ & \\
\hline Resources & $\begin{array}{l}\text { Check that relevant resources } \\
\text { are accessible to the user via } \\
\text { hyperlinks, or as an appendix. } \\
\text { Examples: } \\
\text { 1) other district plans, support } \\
\text { offices information, etc. } \\
\text { 2) federal, state, local agencies' } \\
\text { resources } \\
\text { 3) assessment guidelines, parent } \\
\text { communication letters, } \\
\text { Designated ELD policies }\end{array}$ & \\
\hline \multicolumn{2}{|c|}{ COMMUNICATION } & $\begin{array}{l}\text { Notes and Action Steps } \\
\text { What needs to be communicated and to whom? }\end{array}$ \\
\hline $\begin{array}{c}\text { District } \\
\text { Leadership \& } \\
\text { Stakeholders }\end{array}$ & $\begin{array}{l}\text { Status of plan revision phases is } \\
\text { communicated to LEA leadership. }\end{array}$ & \\
\hline Committees & $\begin{array}{l}\text { Committees or other lead } \\
\text { writers are kept abreast of the } \\
\text { revision phases and how their } \\
\text { feedback affected the revisions. }\end{array}$ & \\
\hline
\end{tabular}




\section{COMPONENT \#4 - STAFFING}

Rationale: Appropriately credentialed personnel, committed to equitable educational programs and learning environments for the advancement of English learners is key to the successful implementation of an EL Master Plan. The process for recruiting, hiring, nurturing, maintaining and monitoring the right personnel ${ }^{18}$ who serve the English learner community is part and parcel of a coherent vision for English learners.

\section{CONTENT OVERVIEW}

- Options for staffing EL programs, including recruitment and retention plans

- Rationale for staffing based on state requirements

- LEA's prioritization process for assigning qualified personnel

The staffing component of the EL Master Plan is aligned with the following principles of the California EL Roadmap (ELR). See Table I for alignment to ELR elements.

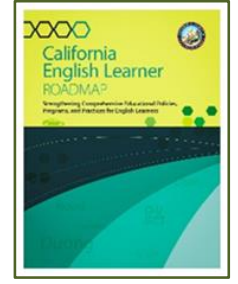

$\checkmark$ Principle 3: System Conditions that Support Effectiveness

$\checkmark$ Principle 4: Alignment and Articulation within and Across Systems

The following Federal Program Monitoring items are addressed:

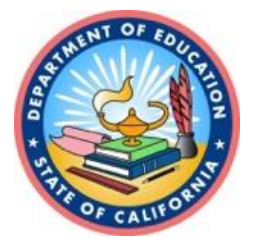

\section{Staffing and Professional Development}

EL I I: Teacher EL Authorization (I I.0)

\footnotetext{
${ }^{18}$ Téllez, K., \& Waxman, H. C. (Eds.). (2006). Preparing quality educators for English Language Learners: Research, policy, and practice. Lawrence Erlbaum Associates.
} 


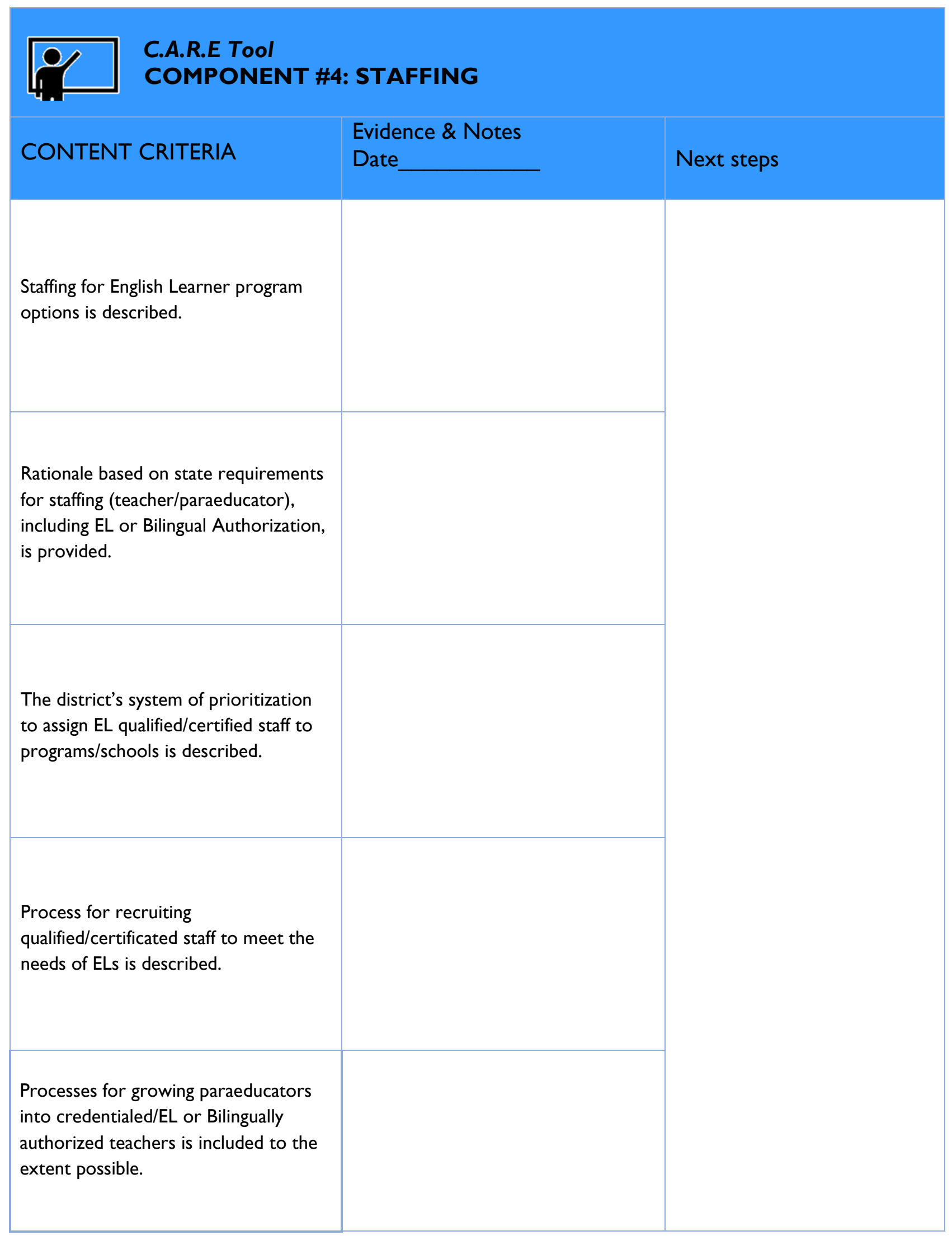




\begin{tabular}{|c|c|c|}
\hline \multicolumn{3}{|c|}{$\begin{array}{l}\text { C.A.R.E. Tool } \\
\text { COMPONENT \#4: STAFFING }\end{array}$} \\
\hline \multicolumn{2}{|c|}{ WRITING CRITERIA } & Notes and Action Steps \\
\hline Revision & $\begin{array}{l}\text { Revise for: } \\
\text { I) meaning } \\
\text { 2) word choice } \\
\text { 3) coherence within and across } \\
\text { district education plans } \\
\text { 4) connectedness within this } \\
\text { chapter }\end{array}$ & \\
\hline $\begin{array}{c}\text { Mandates \& } \\
\text { Guidelines }\end{array}$ & $\begin{array}{l}\text { Check for inclusion of those } \\
\text { that apply: } \\
\text { I) adherence to current federal } \\
\text { and state mandates } \\
\text { 2) district policies and practices } \\
\text { with stated } \\
\text { rationale/expectations }\end{array}$ & \\
\hline Rese & $\begin{array}{l}\text { Confirm that research cited is: } \\
\text { 1) recent } \\
\text { 2) relevant } \\
\text { 3) accurately cited } \\
\text { 4) logical }\end{array}$ & \\
\hline Resources & $\begin{array}{l}\text { Check that relevant resources } \\
\text { are accessible to the user via } \\
\text { hyperlinks, or as an appendix. } \\
\text { Examples: } \\
\text { 1) other district plans, support } \\
\text { offices information, etc. } \\
\text { 2) federal, state, local agencies' } \\
\text { resources } \\
\text { 3) assessment guidelines, parent } \\
\text { communication letters, } \\
\text { Designated ELD policies }\end{array}$ & \\
\hline \multicolumn{2}{|c|}{ COMMUNICATION } & $\begin{array}{l}\text { Notes and Action Steps } \\
\text { What needs to be communicated and to whom? }\end{array}$ \\
\hline $\begin{array}{c}\text { District } \\
\text { Leadership \& } \\
\text { Stakeholders }\end{array}$ & $\begin{array}{l}\text { Status of plan revision phases is } \\
\text { communicated to LEA leadership. }\end{array}$ & \\
\hline Committees & $\begin{array}{l}\text { Committees or other lead } \\
\text { writers are kept abreast of the } \\
\text { revision phases and how their } \\
\text { feedback affected the revisions. }\end{array}$ & \\
\hline
\end{tabular}




\section{COMPONENT \#5 - ACCESS TO CORE CURRICULUM}

Rationale: An LEA's vision and mission for equity and excellence in English Learner education is reflected by system-wide evidence of how ELs experience access, enrollment, and success in all core curricular classes, including Advanced Placement, honors, or gifted courses. An appraisal of a district's daily class schedules, class assignments, and classroom practices for ELs is an opportunity to reflect on whether an LEA's aspirational vision for ELs matches its actions. This component of an EL Master Plan provides an opportunity for districts to affirm their commitment to instructional practices, including Integrated English Language Development ${ }^{19}$, as foundational to the path to equity.

\section{CONTENT OVERVIEW}

- Rationale for access to the core curriculum

- Expectations for rigorous standards-based instruction

- Integrated ELD's role in accessing the core curriculum

- Role of primary language

- ELs' access to advanced, honors, gifted, career track, etc.

The access to core curriculum component of the EL Master Plan is aligned with the following principles of the California EL Roadmap (ELR). See Table I for alignment to ELR elements.

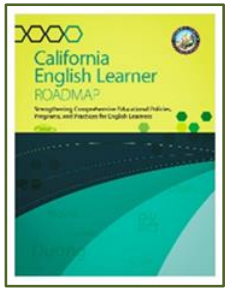

$\checkmark$ Principle I: Assets-Oriented and Needs-Responsive Schools

$\checkmark$ Principle 2: Intellectual Quality of Instruction and Meaningful Access

$\checkmark$ Principle 4: Alignment and Articulation within and Across Systems

The following Federal Program Monitoring items are addressed:

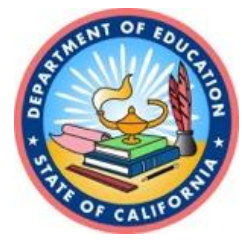

$$
\begin{aligned}
& \text { VII. Teaching and Learning } \\
& \text { EL I5: Access to Standard Instructional Program (I5.0 - 15.2) }
\end{aligned}
$$

\footnotetext{
${ }^{19}$ Integrated ELD emphasizes the interrelated roles of content knowledge, purposes for using English (e.g., explaining, entertaining, arguing), and the language resources (e.g., vocabulary, grammatical structures, discourse practices) through different disciplinary demands (e.g., science, math, ELA, social studies).
} 


\section{COMPONENT \#5: ACCESS TO CORE CURRICULUM}

\section{CONTENT CRITERIA \\ Evidence \& Notes \\ Date \\ Next Steps}

The plan clearly stipulates the expectation for quality, standardsbased, rigorous curriculum and instruction being offered to ELs in all content areas.

Integrated ELD is defined as a requirement to access the core curriculum.

Primary language use and support is highlighted as a way to access the core curriculum.

The rationale for access to the core curriculum is defined and supported by research.

ELs access to Advanced Placement courses, enrichment classes, and Gifted and Talented, college and career programs is detailed. 


\begin{tabular}{|c|c|c|}
\hline \multicolumn{3}{|c|}{$\begin{array}{l}\text { C.A.R.E. Tool } \\
\text { Component \#5: Access to Core Curriculum }\end{array}$} \\
\hline \multicolumn{2}{|c|}{ WRITING CRITERIA } & Notes and Action Steps \\
\hline Revision & $\begin{array}{l}\text { Revise for: } \\
\text { l) meaning } \\
\text { 2) word choice } \\
\text { 3) coherence within and across } \\
\text { district education plans } \\
\text { 4) connectedness within this } \\
\text { chapter }\end{array}$ & \\
\hline $\begin{array}{c}\text { Mandates \& } \\
\text { Guidelines }\end{array}$ & $\begin{array}{l}\text { Check for inclusion of those } \\
\text { that apply: } \\
\text { I) adherence to current federal } \\
\text { and state mandates } \\
\text { 2) district policies and practices } \\
\text { with stated } \\
\text { rationale/expectations }\end{array}$ & \\
\hline Rese & $\begin{array}{l}\text { Confirm that research cited is: } \\
\text { I) recent } \\
\text { 2) relevant } \\
\text { 3) accurately cited } \\
\text { 4) logical }\end{array}$ & \\
\hline Resources & $\begin{array}{l}\text { Check that relevant resources } \\
\text { are accessible to the user via } \\
\text { hyperlinks, or as an appendix. } \\
\text { Examples: } \\
\text { I) other district plans, support } \\
\text { offices information, etc. } \\
\text { 2) federal, state, local agencies' } \\
\text { resources } \\
\text { 3) assessment guidelines, parent } \\
\text { communication letters, } \\
\text { Designated ELD policies }\end{array}$ & \\
\hline \multicolumn{2}{|c|}{ COMMUNICATION } & $\begin{array}{l}\text { Notes and Action Steps } \\
\text { What needs to be communicated and to whom? }\end{array}$ \\
\hline $\begin{array}{c}\text { District } \\
\text { Leadership \& } \\
\text { Stakeholders }\end{array}$ & $\begin{array}{l}\text { Status of plan revision phases is } \\
\text { communicated to LEA leadership. }\end{array}$ & \\
\hline Committees & $\begin{array}{l}\text { Committees or other lead } \\
\text { writers are kept abreast of the } \\
\text { revision phases and how their } \\
\text { feedback affected the revisions. }\end{array}$ & \\
\hline
\end{tabular}




\section{COMPONENT \#6 - ENGLISH LANGUAGE DEVELOPMENT}

Rationale: English learners expand their linguistic repertoires by building on their primary language to learn English as an additional language ${ }^{20}$. The California English Language Arts/English Language Development Framework (CDE, 20I5) defines Designated English Language Development ( $d$-ELD) as a dedicated time during the regular school day when specialized instruction is provided to English learners based on the English Language Development Standards, students' English language proficiency levels, and their English language learning needs. It includes developing English learners' oral language proficiency, discourse practices, reading, and writing abilities necessary for successful participation in academic tasks in all content areas ${ }^{21}$. LEAs need to provide clear guidelines and expectations for d-ELD to provide EL student opportunities to learn English, its forms and functions, new vocabulary, idiomatic expressions and other nuances that will ensure language mastery and successful pathways to biliteracy and reclassification.

\section{CONTENT OVERVIEW}

- Purpose of ELD

- Expectations for ELD instruction and minimum number of daily minutes

- Strategies and practices for ELD, including district prioritized strategies/practices

- Expected ELD progress and monitoring

The ELD component of the EL Master Plan is aligned with the following principles of the California EL Roadmap (ELR). See Table I for alignment to ELR elements.

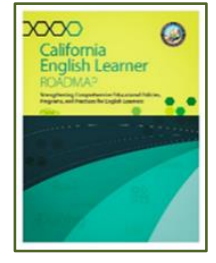

$\checkmark$ Principle I: Assets-Oriented and Needs-Responsive Schools

$\checkmark$ Principle 2: Intellectual Quality of Instruction and Meaningful Access

$\checkmark$ Principle 4: Alignment and Articulation within and Across Systems

The following Federal Program Monitoring items are addressed:

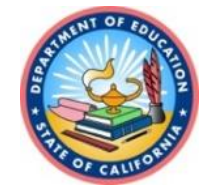

$$
\begin{aligned}
& \text { VII. Teaching and Learning } \\
& \text { EL I4: ELD (I4.0 - I4.3) }
\end{aligned}
$$

\footnotetext{
${ }^{20}$ National Academies of Sciences, Engineering, and Medicine. (2017). Promoting the educational success of children and youth learning English: Promising futures. Author.

${ }^{21}$ Saunders, W., Goldenberg, C., \& Marcelletti, D. (20I3). English language development: Guidelines for instruction. American Educator, 27(2), 13-25. https://files.eric.ed.gov/fulltext/EJI0|4023.pdf
} 


\begin{tabular}{|c|c|c|}
\hline \multirow[b]{2}{*}{ CONTENT CRITERIA } & 6: ENGLISH LA & \multirow[b]{2}{*}{ Next Steps } \\
\hline & $\begin{array}{l}\text { Evidence \& Notes } \\
\text { Date }\end{array}$ & \\
\hline $\begin{array}{l}\text { The purpose for a comprehensive } \\
\text { English Language Development } \\
\text { program (Integrated and Designated } \\
\text { ELD) is stated and supported by } \\
\text { research/reports (e.g., California } \\
\text { ELA/ELD Framework). }\end{array}$ & & \\
\hline $\begin{array}{l}\text { There is a clear description of } \\
\text { designated ELD for ELs, with } \\
\text { expectations for daily minimum } \\
\text { number of minutes across grade levels. }\end{array}$ & & \\
\hline $\begin{array}{l}\text { The plan details secondary designated } \\
\text { ELD course sequences and placement } \\
\text { criteria. }\end{array}$ & & \\
\hline $\begin{array}{l}\text { Research-based practices and } \\
\text { pedagogies to implement designated } \\
\text { ELD are described. }\end{array}$ & & \\
\hline $\begin{array}{l}\text { There is a stated commitment and } \\
\text { described process to monitor student } \\
\text { language proficiency, including students } \\
\text { who have reclassified as fluent English } \\
\text { proficient (e.g. Language Appraisal } \\
\text { Team). }\end{array}$ & & \\
\hline
\end{tabular}




\section{C.A.R.E. Tool \\ COMPONENT \#6: English Language Development}

\section{WRITING CRITERIA}

\section{Revise for:}

I) meaning

Revision

ก
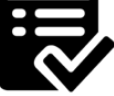

(n)

\section{Mandates \& Guidelines

RULES

Research

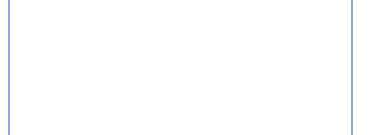

2) word choice chapter

that apply: with stated

I) recent

2) relevant

4) logical Examples:

3) coherence within and across district education plans

4) connectedness within this

\section{Check for inclusion of those}

I) adherence to current federal and state mandates

2) district policies and practices rationale/expectations

Confirm that research cited is:

3) accurately cited

Check that relevant resources are accessible to the user via hyperlinks, or as an appendix.

Resources

I) other district plans, support offices information, etc.

2) federal, state, local agencies' resources

3) assessment guidelines, parent communication letters,

Designated ELD policies

\section{COMMUNICATION}

\begin{tabular}{|l|l|}
\hline $\begin{array}{c}\text { District } \\
\text { Leadership \& } \\
\text { Stakeholders }\end{array}$ & $\begin{array}{l}\text { Status of plan revision phases is } \\
\text { communicated to LEA leadership. }\end{array}$ \\
\hline
\end{tabular}




\section{COMPONENT \#7 - PROFESSIONAL LEARNING}

Rationale: Doctors, lawyers, engineers, accountants and others in varied professions participate in professional learning to keep abreast of: current research, changes in their field, or updated technology and resources that will support them in meeting the changing needs of their clients. Professional learning is essential for educators, not only for the reasons other professionals engage in building capabilities, but also because the students and families we serve have needs that are not only diverse, but constantly changing based on their context. Among other researchers, Linda Darling Hammond emphasizes the potential of high-quality PD to improve student outcomes. ${ }^{22}$ An EL Master Plan is an advocacy document intending to bring forth practices that will lead to equity for English learners. Professional learning is key in ensuring that educators and leaders are equipped to improve student outcomes ${ }^{23}$.

\section{CONTENT OVERVIEW}

- Rationale for professional learning to build and sustain the capacity of English learners

- Foundational knowledge expectations for teachers of ELs

- Clarity around responsibilities of district and site for coherent and aligned professional learning

- Connectedness between professional learning for EL educators and LEA's educational plans

The professional learning component of the EL Master Plan is aligned with the following principles of the California EL Roadmap (ELR). See Table I for alignment to ELR elements.

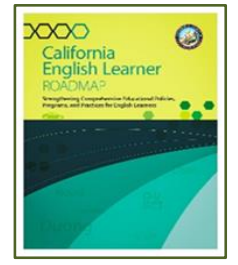

\section{Principle 3: System Conditions that Support Effectiveness}

$\checkmark$ Principle 4: Alignment and Articulation within and Across Systems

The following Federal Program Monitoring items are addressed:

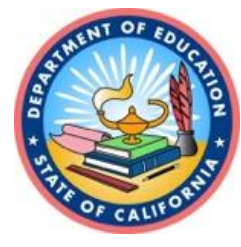

V. Staffing and Professional Learning

EL 12: Professional Development Specific to English learners (12.0 -

12.1)

\footnotetext{
${ }^{22}$ Darling-Hammond, L., Hyler, M. E., Gardner, M. (2017). Effective Teacher Professional Development. Palo Alto, CA: Learning Policy Institute. https://learningpolicyinstitute.org/product/teacher-prof-dev

${ }^{23}$ Lavadenz, M. (2010/20I I). From Theory to Practice for Teachers of English learners. The CATESOL Journal, 22(I), I8-47.
} 


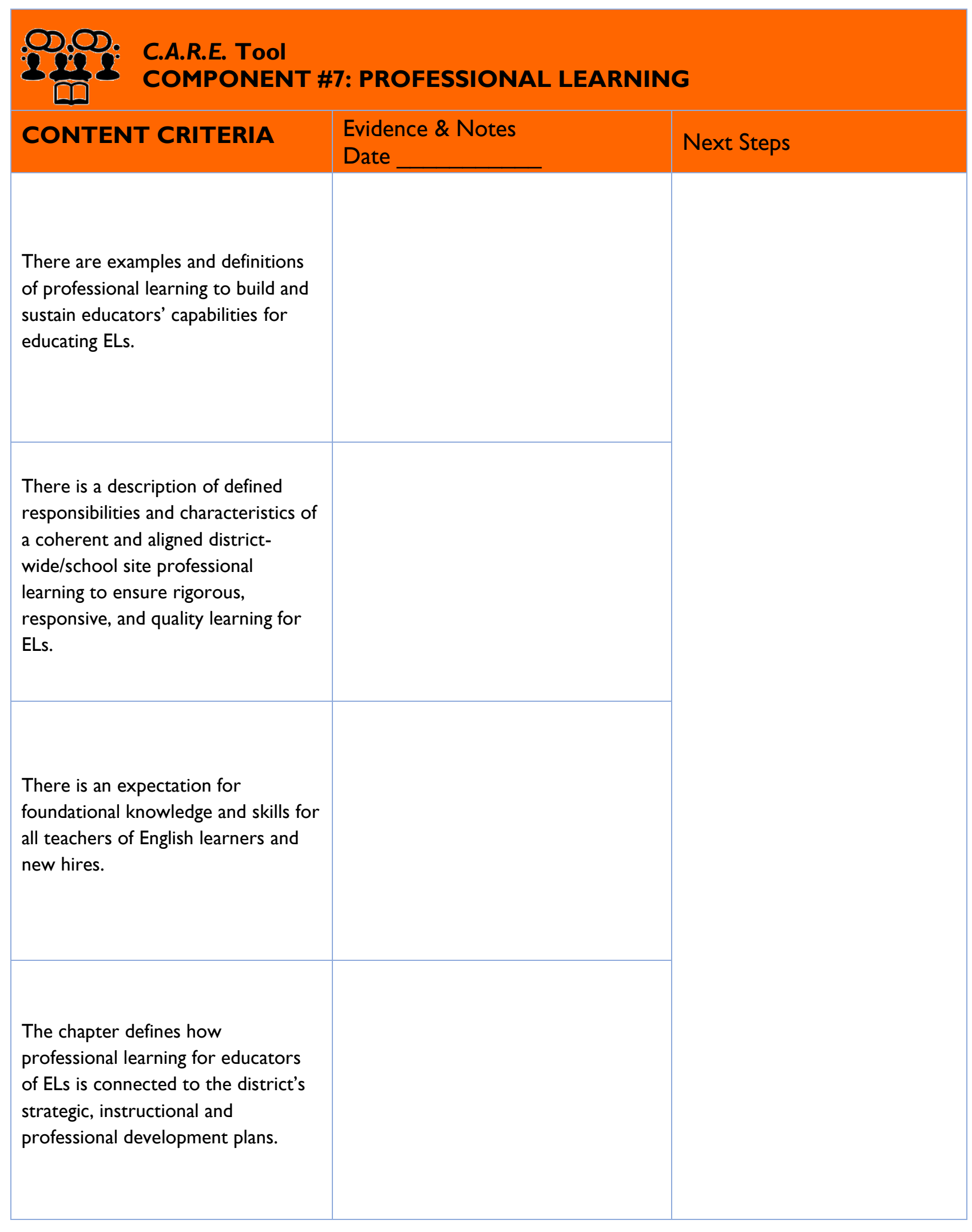




\begin{tabular}{|c|c|c|}
\hline \multicolumn{3}{|c|}{$\begin{array}{l}\text { C.A.R.E. Tool } \\
\text { COMPONENT \#7: Professional Learning }\end{array}$} \\
\hline \multicolumn{2}{|c|}{ WRITING CRITERIA } & Notes and Action Steps \\
\hline Revision & $\begin{array}{l}\text { Revise for: } \\
\text { l) meaning } \\
\text { 2) word choice } \\
\text { 3) coherence within and across } \\
\text { district education plans } \\
\text { 4) connectedness within this } \\
\text { chapter }\end{array}$ & \\
\hline $\begin{array}{c}\text { Mandates \& } \\
\text { Guidelines }\end{array}$ & $\begin{array}{l}\text { Check for inclusion of those } \\
\text { that apply: } \\
\text { I) adherence to current federal } \\
\text { and state mandates } \\
\text { 2) district policies and practices } \\
\text { with stated } \\
\text { rationale/expectations }\end{array}$ & \\
\hline Research & $\begin{array}{l}\text { Confirm that research cited is: } \\
\text { I) recent } \\
\text { 2) relevant } \\
\text { 3) accurately cited } \\
\text { 4) logical }\end{array}$ & \\
\hline Resources & $\begin{array}{l}\text { Check that relevant resources } \\
\text { are accessible to the user via } \\
\text { hyperlinks, or as an appendix. } \\
\text { Examples: } \\
\text { 1) other district plans, support } \\
\text { offices information, etc. } \\
\text { 2) federal, state, local agencies' } \\
\text { resources } \\
\text { 3) assessment guidelines, parent } \\
\text { communication letters, } \\
\text { Designated ELD policies }\end{array}$ & \\
\hline COMMUNICA & $\mathrm{ION}$ & $\begin{array}{l}\text { Notes and Action Steps } \\
\text { What needs to be communicated and to whom? }\end{array}$ \\
\hline $\begin{array}{c}\text { District } \\
\text { Leadership \& } \\
\text { Stakeholders }\end{array}$ & $\begin{array}{l}\text { Status of plan revision phases is } \\
\text { communicated to LEA leadership. }\end{array}$ & \\
\hline Committees & $\begin{array}{l}\text { Committees or other lead } \\
\text { writers are kept abreast of the } \\
\text { revision phases and how their } \\
\text { feedback affected the revisions. }\end{array}$ & \\
\hline
\end{tabular}




\section{COMPONENT \#8 - FAMILY-SCHOOL PARTNERSHIPS}

Rationale: The original Elementary and Secondary Act (ESEA 1964) emphasized the essential role families play in the educational success of their children. Since then, substantial research continues to provide evidence that "effective family engagement can contribute to improved student outcomes and to closing persistent achievement gaps among students of different racial and ethnic backgrounds and family income levels." ${ }^{24}$ Hattie's meta-analysis study on student learning identified parental engagement as a strategy that can contribute to more than one year's growth in student learning. ${ }^{25}$ Implementing a Dual Capacity-Building Framework can also support parent leadership development. ${ }^{26}$ Engaged EL families and the communities they represent are an LEA's partner in ensuring equity for their children.

\section{CONTENT OVERVIEW}

- Role of families in the education of ELs

- Expectations and systems for EL families, including students, to engage in district activities/education

- Forms and purpose of communicating with families

- Primary language communication/translation

- Role of advisory committees.

- Rights of parents/families

- Capacity building for families and community

The family-school partnerships component of the EL Master Plan is aligned with the following principles of the California EL Roadmap (ELR). See Table I for alignment to ELR elements.

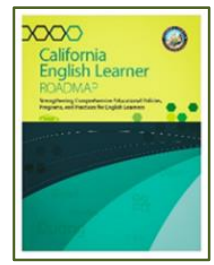

Principle I: Assets-Oriented and Needs-Responsive Schools

$\checkmark$ Principle 3: System Conditions that Support Effectiveness

$\checkmark$ Principle 4: Alignment and Articulation within and Across Systems

The following Federal Program Monitoring items are addressed:

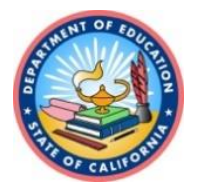

I. Involvement

EL 0I: English Learner Advisory (I.0-I.2)

EL 02: District English Learner Advisory Committee (2.0-2.3)

\footnotetext{
${ }^{24}$ California Department of Education. (20I7). Family Engagement Toolkit: Continuous Improvement Through an Equity Lens. https://www.cde.ca.gov/fg/aa/lc/documents/family-engagement.pdf

${ }^{25}$ Corwin (2018). Visible Learning Plus: 250+ Influences on Student Achievement [Synthesis]. https://us.corwin.com/sites/default/files/250_influences_10.1.2018.pdf

${ }^{26}$ Mapp, K. \& Kuddner, P. (20I4). Partners in Education: The Dual Capacity-Building Framework for Family-School Partnerships. AIR: Washington DC.
} 


\begin{tabular}{|c|c|c|}
\hline \multirow[b]{2}{*}{ CONTENT CRITERIA } & AMILY-SCHOO & \multirow[b]{2}{*}{ Next Steps } \\
\hline & $\begin{array}{l}\text { Evidence \& Notes } \\
\text { Date }\end{array}$ & \\
\hline $\begin{array}{l}\text { The plan details a commitment to the } \\
\text { role of families as partners and assets in } \\
\text { the education and success of their } \\
\text { English learners. }\end{array}$ & & \\
\hline $\begin{array}{l}\text { The expectations and types of } \\
\text { engagement of English Learner families } \\
\text { align with the district's standards for } \\
\text { family and student engagement. }\end{array}$ & & \\
\hline $\begin{array}{l}\text { Forms of communicating with parents } \\
\text { about: program options, student } \\
\text { progress towards ELD, student } \\
\text { progress in core classes, reclassification, } \\
\text { access to enrichment-intervention- } \\
\text { supplemental programs, college } \\
\text { readiness, etc. are included and align } \\
\text { with the district's strategic } \\
\text { plan/instructional plan. }\end{array}$ & & \\
\hline $\begin{array}{l}\text { The rationale, role and responsibilities } \\
\text { of family and community in federal, state } \\
\text { and district advisory committees is } \\
\text { communicated in the plan. }\end{array}$ & & \\
\hline $\begin{array}{l}\text { The district's responsibilities and } \\
\text { commitment for communicating with } \\
\text { parents in their primary language \& } \\
\text { providing translation are clearly } \\
\text { delineated. }\end{array}$ & & \\
\hline $\begin{array}{l}\text { The family, parent or guardian rights } \\
\text { and processes to advocate for their } \\
\text { English learners align with federal, state } \\
\text { and district mandates and are explicitly } \\
\text { described in the plan. }\end{array}$ & & \\
\hline $\begin{array}{l}\text { The plan details district and schools' } \\
\text { roles and responsibilities in building } \\
\text { family and community capacity on: ELD, } \\
\text { assessment, core instructional programs } \\
\text { and services for English learners. }\end{array}$ & & \\
\hline
\end{tabular}




\section{C.A.R.E. Tool \\ COMPONENT \#8: Family-School Partnerships}

\section{WRITING CRITERIA}

Notes and Action Steps

\begin{tabular}{|c|c|c|}
\hline Revision & $\begin{array}{l}\text { Revise for: } \\
\text { l) meaning } \\
\text { 2) word choice } \\
\text { 3) coherence within and across } \\
\text { district education plans } \\
\text { 4) connectedness within this } \\
\text { chapter }\end{array}$ & \\
\hline $\begin{array}{c}\text { Mandates \& } \\
\text { Guidelines }\end{array}$ & $\begin{array}{l}\text { Check for inclusion of those } \\
\text { that apply: } \\
\text { I) adherence to current federal } \\
\text { and state mandates } \\
\text { 2) district policies and practices } \\
\text { with stated } \\
\text { rationale/expectations }\end{array}$ & \\
\hline Research & $\begin{array}{l}\text { Confirm that research cited is: } \\
\text { I) recent } \\
\text { 2) relevant } \\
\text { 3) accurately cited } \\
\text { 4) logical }\end{array}$ & \\
\hline Resources & $\begin{array}{l}\text { Check that relevant resources } \\
\text { are accessible to the user via } \\
\text { hyperlinks, or as an appendix. } \\
\text { Examples: } \\
\text { I) other district plans, support } \\
\text { offices information, etc. } \\
\text { 2) federal, state, local agencies' } \\
\text { resources } \\
\text { 3) assessment guidelines, parent } \\
\text { communication letters, } \\
\text { Designated ELD policies }\end{array}$ & \\
\hline \multicolumn{2}{|c|}{ COMMUNICATION } & $\begin{array}{l}\text { Notes and Action Steps } \\
\text { What needs to be communicated and to whom? }\end{array}$ \\
\hline $\begin{array}{c}\text { District } \\
\text { Leadership \& } \\
\text { Stakeholders }\end{array}$ & $\begin{array}{l}\text { Status of plan revision phases is } \\
\text { communicated to LEA leadership. }\end{array}$ & \\
\hline Committees & $\begin{array}{l}\text { Committees or other lead } \\
\text { writers are kept abreast of the } \\
\text { revision phases and how their } \\
\text { feedback affected the revisions. }\end{array}$ & \\
\hline
\end{tabular}




\section{COMPONENT \#9 - ASSESSMENT AND STUDENT MONITORING}

Rationale: A comprehensive assessment program ${ }^{27}$ includes both formative and summative language and content area assessments, as well as a system for educators to monitor individual student progress. Summative English language proficiency and content standards assessments give us a snapshot of how students are performing in relation to the ELD and grade-level standards, once a year. Language assessments give us significant data that allows us to evaluate student progress in the development of a second language, given the expectation of a minimum of one level of growth per year.

Content standards summative assessments provide data to compare subgroups, thus analyzing whether gaps among student groups are widening, decreasing or maintaining. However, these summative assessments do not provide the type of information that formative assessments can offer ${ }^{28}$, namely the opportunity to plan, act and intervene in a timely manner to improve student learning. The EL Master Plan is a guiding document that clarifies and systematizes the way EL student learning is monitored and addressed.

\section{CONTENT OVERVIEW}

- Comprehensive assessment program

- Purpose/time for each assessment

- ELD assessments to measure progress in speaking, listening, reading and writing

- Structures and systems to intervene based on student progress

The assessment and student monitoring chapter of the EL Master Plan is aligned with the following principles of the California EL Roadmap. See Table I for alignment to ELR elements.

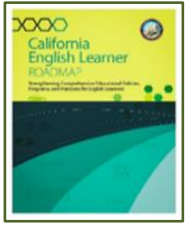

\section{Principle 3: System Conditions that Support Effectiveness}

$\checkmark$ Principle 4: Alignment and Articulation within and Across Systems

The following Federal Program Monitoring items are addressed:

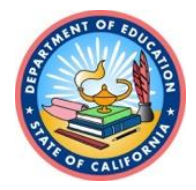

IV. Standards Assessments and Accountability - EL 09: Evaluation of Title

III-Funded Services and Programs $(9.0-9.1)$

VII. Teaching and Learning - ELI5: Access to Standard Instructional

Program (15.2)

\footnotetext{
${ }^{27}$ Foster, E. (2019). How assessment supports English learners. The Learning Professional, 40(2), 22-25. https://eric.ed.gov/?id=EJI215367

${ }^{28}$ Alvarez, L., Ananda, S., Walqui, A., Sato, E., \& Rabinowitz, S. (20I4). Focusing formative assessment on the needs of English Language Learners. WestEd. https://www.wested.org/wpcontent/uploads/2016/I I/I391626953FormativeAssessment_report5-3.pdf
} 


\begin{tabular}{|c|c|c|}
\hline \multicolumn{3}{|c|}{$\begin{array}{l}\text { C.A.R.E. Tool } \\
\text { COMPONENT \# 9: ASSESSMENT \& STUDENT MONITORING }\end{array}$} \\
\hline CONTENT CRITERIA & $\begin{array}{l}\text { Evidence \& Notes } \\
\text { Date }\end{array}$ & Next Steps \\
\hline $\begin{array}{l}\text { The plan includes a comprehensive } \\
\text { assessment program for monitoring: I) ELD } \\
\text { progress monitoring, 2) core curriculum } \\
\text { progress monitoring and } 3 \text { ) reclassification. }\end{array}$ & & \\
\hline $\begin{array}{l}\text { The comprehensive assessment program } \\
\text { includes: I) standardized state language } \\
\text { assessments, 2) standardized state core } \\
\text { curriculum assessments, 3) common } \\
\text { formative district assessments for ELD and } \\
\text { core, and/or 4) curriculum/publisher's } \\
\text { assessments for language and content, } \\
\text { and/or 5) teacher developed assessments. }\end{array}$ & & \\
\hline $\begin{array}{l}\text { ELD assessments measure progress of } \\
\text { English learners in speaking, listening, reading } \\
\text { and writing. }\end{array}$ & & \\
\hline $\begin{array}{l}\text { The intent and usage for each assessment is } \\
\text { clearly identified in the plan. }\end{array}$ & & \\
\hline $\begin{array}{l}\text { There is a timeline or recommended } \\
\text { periods for testing based on federal, state, } \\
\text { and district mandates/guidelines. }\end{array}$ & & \\
\hline $\begin{array}{l}\text { The plan includes structures (e.g., Language } \\
\text { Appraisal Team), systems, appropriate } \\
\text { timelines and processes for convening and } \\
\text { intervening when English learners, based on } \\
\text { typology, are not making adequate progress. } \\
\text { Structures include teams of } \\
\text { knowledgeable educators and parents } \\
\text { such as: principal, bilingual coordinator, } \\
\text { EL teacher, parent, counselor, special } \\
\text { education specialist, etc. } \\
\text { The processes for convening and } \\
\text { intervening clearly delineate what data, } \\
\text { artifacts and evidence needs to be } \\
\text { considered in the decision-making } \\
\text { process }\end{array}$ & & \\
\hline
\end{tabular}




\section{C.A.R.E. Tool \\ COMPONENT \# 9: Assessment and Student Monitoring}

\section{WRITING CRITERIA}

Revise for:

1) meaning

2) word choice

3) coherence within and across district education plans

4) connectedness within this chapter

\section{Check for inclusion of those} that apply:

\section{Mandates \& Guidelines}

RULES

I) adherence to current federal and state mandates

2) district policies and practices with stated rationale/expectations
Notes and Action Steps

Confirm that research cited is:

\begin{tabular}{|l|ll} 
Research & I) & recent \\
\hline & 2) & relevant \\
\hline & 3) & accurately cited \\
\hline
\end{tabular}

Check that relevant resources are accessible to the user via hyperlinks, or as an appendix.

\section{Resources} Examples:

I) other district plans, support offices information, etc.

2) federal, state, local agencies' resources

3) assessment guidelines, parent communication letters, Designated ELD policies

\section{COMMUNICATION}

\section{Notes and Action Steps} What needs to be communicated and to whom?

\begin{tabular}{|l|l|}
\hline $\begin{array}{c}\text { District } \\
\text { Leadership \& } \\
\text { Stakeholders }\end{array}$ & $\begin{array}{l}\text { Status of plan revision phases is } \\
\text { communicated to LEA leadership. }\end{array}$ \\
\hline
\end{tabular}




\section{COMPONENT \#IO - PROGRAM MONITORING AND EVALUATION}

Rationale: District and school leaders are responsible for evaluating the effectiveness of language acquisition, academic and other programs for $\mathrm{ELs}^{29}$. The EL Master Plan provides an opportunity to define and describe the types of programs available, as well as the full range of access. LEAs must also meaningfully engage stakeholders in addressing research, federal and state policies to inform the processes for analyzing the effectiveness and improvement of comprehensive programs for ELs, including how to equitably allocate resources as required by the Local Control Funding Formula and the Local Control and Accountability Plans ${ }^{30}$.

\section{CONTENT OVERVIEW}

- Plan for English Learner program evaluation

- Federal, state and district requirements and evaluation processes

- Success criteria for ELs linguistic and academic outcomes

- Core base program vs. supplemental defined

- Evaluation of base/supplemental funding

The program monitoring and evaluation component of the EL Master Plan is aligned with the following principles of the California EL Roadmap (ELR). See Table I for alignment to ELR elements.

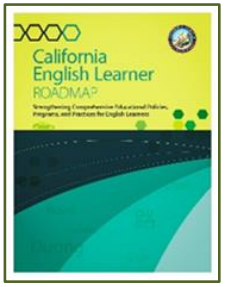

$\checkmark$ Principle 3: System Conditions that Support Effectiveness

$\checkmark$ Principle 4: Alignment and Articulation within and Across Systems

The following Federal Program Monitoring items are addressed:

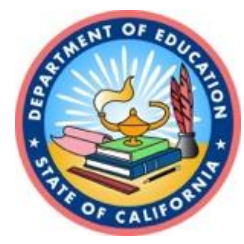

II. Governance and Administration - EL 05: EL Program Inclusion in the SPSA [Schoolwide] (5.0-5.2)

III. Funding - EL 07: Supplement, Not Supplant with Title III $(7.0-7.1)$

IV. Standards Assessments and Accountability - EL 09: Evaluation of Title III-Funded Services and Programs $(9.0-9.1)$

\footnotetext{
${ }^{29}$ U.S. Department of Education, Office of English Language Acquisition. (2017). English Learner Tool Kit (2nd Rev. ed.). Washington, DC: Author

${ }^{30}$ California Department of Education, Local Control Funding Formula (AB 97, SB 9I, and SB 97). https://www.cde.ca.gov/fg/aa/lc/index.asp Local Control and Accountability Plans (Education Codes 52060- 52077). https://www.cde.ca.gov/re/lc/
} 


\begin{tabular}{|c|c|c|}
\hline \multirow[b]{2}{*}{ CONTENT CRITERIA } & OGRAM MONIT & \multirow[b]{2}{*}{ Next Steps } \\
\hline & $\begin{array}{l}\text { Evidence \& Notes } \\
\text { Date }\end{array}$ & \\
\hline $\begin{array}{l}\text { The plan includes English Learner } \\
\text { program evaluation questions and } \\
\text { criteria to support continuous } \\
\text { monitoring and improvement processes. }\end{array}$ & & \\
\hline $\begin{array}{l}\text { The plan includes requirements and } \\
\text { evaluation processes to gauge } \\
\text { compliance with federal, state and } \\
\text { district guidelines. }\end{array}$ & & \\
\hline $\begin{array}{l}\text { There are identified measures (e.g., } \\
\text { qualitative and quantitative data) and } \\
\text { criteria to determine the effectiveness } \\
\text { of the plan as it pertains to English } \\
\text { learner linguistic and academic } \\
\text { outcomes. }\end{array}$ & & \\
\hline $\begin{array}{l}\text { The plan defines the difference between } \\
\text { base programs and differentiated or } \\
\text { supplemental supports for English } \\
\text { learners. }\end{array}$ & & \\
\hline $\begin{array}{l}\text { There is a description of how the LEA } \\
\text { equitably allocates resources as } \\
\text { required by the Local Control Funding } \\
\text { Formula and the Local Control and } \\
\text { Accountability Plans. }\end{array}$ & & \\
\hline
\end{tabular}




\section{C.A.R.E. Tool}

COMPONENT \#I 0: Program Monitoring and Evaluation

\begin{tabular}{|c|c|c|}
\hline \multicolumn{2}{|c|}{ WRITING CRITERIA } & \multirow[t]{2}{*}{ Notes and Action Steps } \\
\hline Revision & $\begin{array}{l}\text { Revise for: } \\
\text { 1) meaning } \\
\text { 2) word choice } \\
\text { 3) coherence within and across } \\
\text { 4istrict education plans } \\
\text { 4) connectedness within this } \\
\text { chapter }\end{array}$ & \\
\hline $\begin{array}{c}\text { Mandates \& } \\
\text { Guidelines } \\
\end{array}$ & $\begin{array}{l}\text { Check for inclusion of those } \\
\text { that apply: } \\
\text { 1) adherence to current federal } \\
\text { and state mandates } \\
\text { 2) district policies and practices } \\
\text { with stated } \\
\text { rationale/expectations }\end{array}$ & \\
\hline Research & $\begin{array}{l}\text { Confirm that research cited is: } \\
\text { 1) recent } \\
\text { 2) relevant } \\
\text { 3) accurately cited } \\
\text { 4) logical }\end{array}$ & \\
\hline 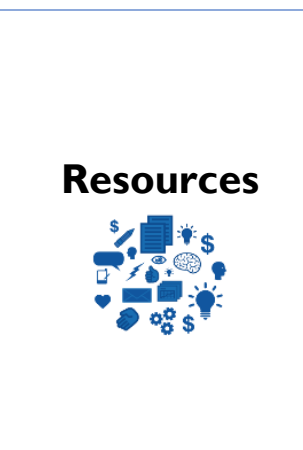 & $\begin{array}{l}\text { Check that relevant resources } \\
\text { are accessible to the user via } \\
\text { hyperlinks, or as an appendix. } \\
\text { Examples: } \\
\text { 1) other district plans, support } \\
\text { offices information, etc. } \\
\text { 2) federal, state, local agencies' } \\
\text { resources } \\
\text { 3) assessment guidelines, parent } \\
\text { communication letters, } \\
\text { Designated ELD policies }\end{array}$ & \\
\hline \multicolumn{2}{|c|}{ COMMUNICATION } & $\begin{array}{l}\text { Notes and Action Steps } \\
\text { What needs to be communicated and to whom? }\end{array}$ \\
\hline $\begin{array}{c}\text { District } \\
\text { Leadership \& } \\
\text { Stakeholders }\end{array}$ & $\begin{array}{l}\text { Status of plan revision phases is } \\
\text { communicated to LEA leadership. }\end{array}$ & \\
\hline Committees & $\begin{array}{l}\text { Committees or other lead } \\
\text { writers are kept abreast of the } \\
\text { revision phases and how their } \\
\text { feedback affected the revisions. }\end{array}$ & \\
\hline
\end{tabular}




\section{CONCLUSION: THE IMPORTANCE OF LEADERSHIP}

Throughout the EL Master Plan development process, district and site-leaders have the opportunity to lead and engage in inquiry, input, and iterative writing cycles to influence the development of an equity-focused EL Master Plan. In Coherence: The Right Drivers in Action for Schools, Districts, and Systems, ${ }^{31}$ Fullan and Quinn identify four drivers that impact student learning and outcomes. These drivers are: focusing direction, cultivating collaborative cultures, deepening learning, and securing accountability. All of these are grounded in leadership. Fullan and Quinn describe a leadership where the LEA, all its departments and school-based leadership all speak with the same voice. The importance of

Most studies that have looked at the issue of leadership have demonstrated that successful schools have effective leadership. In a study of whole-school reform Castellano et al. indicate, "Strong principals and other leaders.... have been critical in setting an agenda and one for change."

- In Howard et al. (2018, page 46) leadership is also highlighted in the Guiding Principles for Dual Language Education ${ }^{32}$ published by The Center for Applied Linguistics. Thus, the EL Master Plan should weave the role of leaders across its components/chapters to ensure coherence throughout the system in providing the rich, rigorous instruction and services that ELs deserve.

As leadership teams engage in the applied use of this English Learner Master Plan Playbook, we recommend that the following elements be

considered: I) the LEA superintendent and the leadership's vision and commitment to providing an equity-driven, rigorous education to English learners, 2) the LEA leadership's focus on the success of English learners so they may be prepared for college and/or careers, 3) the LEA and site leadership's commitment to supporting, implementing and monitoring the actualization of the EL Master Plan, and 4) the LEA's vision for promoting biliteracy and the attainment of the distinguished SEAL of biliteracy.

\footnotetext{
${ }^{31}$ Fullan, M. \& Quinn, J. (2016). Coherence: The Right Drivers in Action for Schools, Districts and Systems. Corwin-Sage Publications and Ontario Principals' Council.

32 Howard, E. R., Lindholm-Leary, K. J., Rogers, D., Olague, N., Medina, J., Kennedy, D., Sugarman, J., \& Christian, D. (20I8). Guiding Principles for Dual Language Education (3rd ed.). Center for A pplied Linguistics.
} 


\section{APPENDICES}

\section{APPENDIX I. EQUITABLE, COHERENT, AND SUSTAINABLE SYSTEMS}

These resources support the development of an EL Master Plan focused on the first of four goals outlined in our Playbook which are: (I) Equitable, Coherent, and Sustainable Systems (2) Equity-driven Processes, Research-based Programs, and Practices (3) Family-Community Engagement; and (4) Accountability.

Goal I: Equitable, Coherent, and Sustainable Systems can be written as a series of chapters, or any combination of chapters and includes 4 key components:

- Commitment and Purpose

- Responding to Diverse Learners

- Program Options

- Staffing

\section{RESOURCES}

\section{Table AI. Equitable, Coherent, and Sustainable Systems - Resources to Support} English Learner Master Plan Development

Resource

A Matter of Design: English Learner Program Models in KI 2 Education. Washington, DC: Migration Policy Institute https://www.migrationpolicy.org/rese arch/english-learner-program-modelsk-12-education

\section{Summary}

Sugarman (2018) describes the characteristics of some of the most common program types-dual language, transitional bilingual education, and English only-and examines the factors that shape schools' decisions to use a particular model or set of models. This resource presents a clear and concise comparison table across program types.

California Practitioners' Guide for Educating English learners with Disabilities

https://www.cde.ca.gov/sp/se/ac/docu ments/ab2785guide.pdf

Guiding Principles for Dual Language Education- Third Edition

http://www.cal.org/resourcecenter/publications-products/guidingprinciples-3
This publication from the California Department of Education offers guidance for educators and school communities to identify, refer, support, assess, and reclassify English learners with disabilities (CDE).

This latest edition offers a description of the 7 Guiding Principles for dual language reflecting learning from research and practice supported by updated literature reviews. The principles are organized into 7 strands which include a review of literature on research and best 


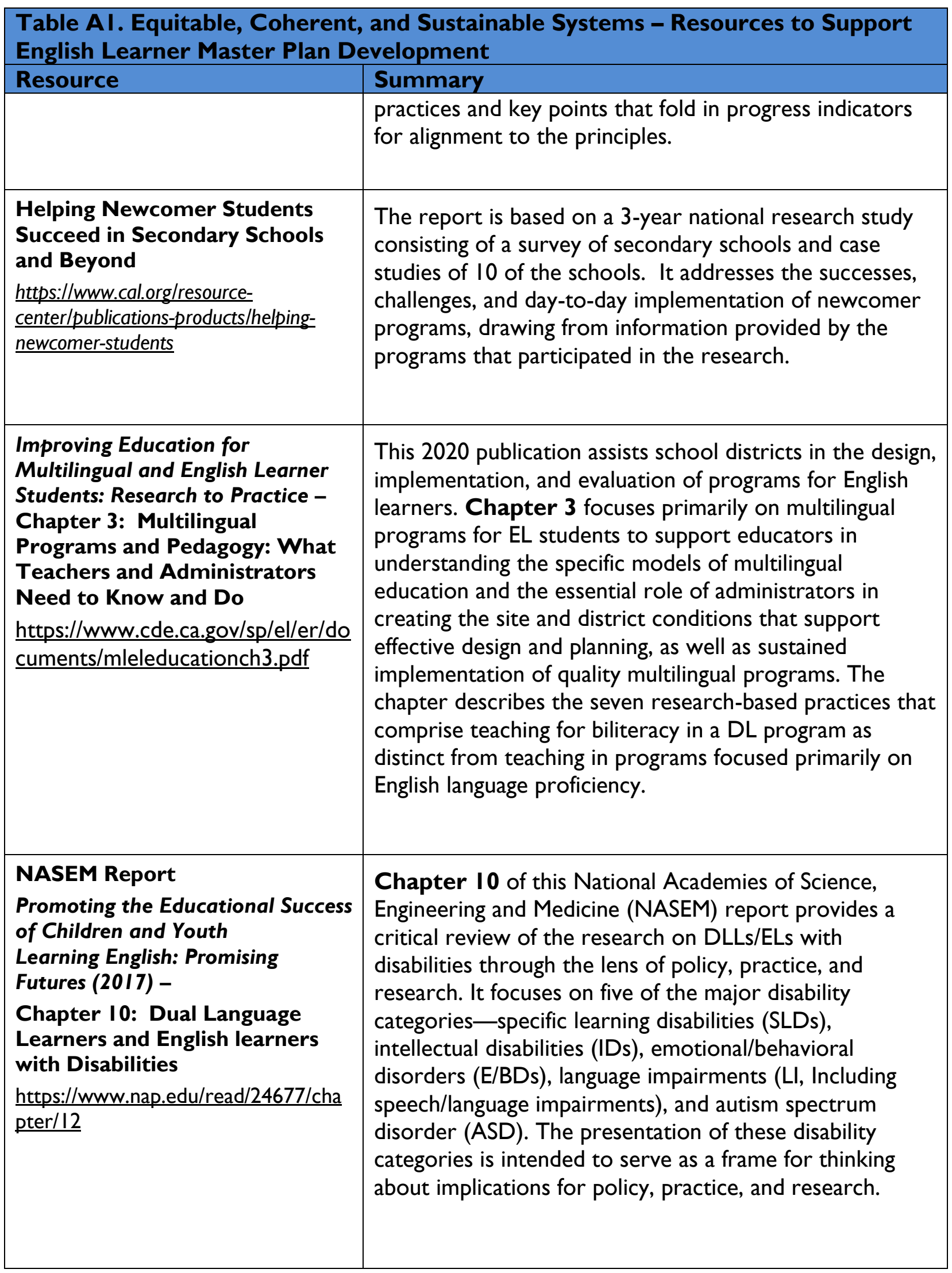




\begin{tabular}{|c|c|}
\hline Resource & Summary \\
\hline $\begin{array}{l}\text { NASEM Report } \\
\text { Promoting the Educational Success } \\
\text { of Children and Youth } \\
\text { Learning English: Promising } \\
\text { Futures (20I7) } \\
\text { Chapter 4: Dual Language } \\
\text { Learners: Capacities and } \\
\text { Influences on Language } \\
\text { Development } \\
\text { https://www.nap.edu/read/24677/cha } \\
\text { pter/6 } \\
\text { Chapter } 7 \text { Programs for English } \\
\text { learners in Grades Prek- I } 2 \\
\text { https://www.nap.edu/read/24677/cha } \\
\text { pter/9 }\end{array}$ & $\begin{array}{l}\text { Chapter } 4 \text { of this National Academies of Science, } \\
\text { Engineering and Medicine (NASEM) report focuses on } \\
\text { reviewing the evidence on young children's underlying } \\
\text { capacity for dual language development and examining the } \\
\text { factors that may influence the full expression of this } \\
\text { capacity among DLLs in the United States. } \\
\text { Chapter } 7 \text { provides an overview of the English-only and } \\
\text { bilingual programs that serve ELs in grades pre-K to I } 2 \\
\text { and the evaluation research that compares outcomes for } \\
\text { ELs instructed in English-only programs with ELs } \\
\text { instructed in bilingual programs. This is followed by a } \\
\text { review of the research on instructional practices for } \\
\text { developing ELs' oral language proficiency in grades K-I2. } \\
\text { Next, the chapter reviews district-wide practices related } \\
\text { to the educational progress of ELs and examines the role } \\
\text { of family engagement in ELs' educational success. }\end{array}$ \\
\hline $\begin{array}{l}\text { NASEM Report } \\
\text { Promoting the Educational Success } \\
\text { of Children and Youth } \\
\text { Learning English: Promising } \\
\text { Futures (20I7) } \\
\text { Chapter 9: Promising and } \\
\text { Effective Practices for Specific } \\
\text { Populations of English learners } \\
\text { Grades PreK-I } 2 \\
\text { https://www.nap.edu/read/24677/cha } \\
\text { pter/II }\end{array}$ & $\begin{array}{l}\text { Chapter } 9 \text { of this National Academies of Science, } \\
\text { Engineering and Medicine (NASEM) report focuses on } \\
\text { reviewing programs for ELs who are gifted and talented; } \\
\text { living in migrant families that work in food-production } \\
\text { industries; and living on tribal lands, specifically, American } \\
\text { Indians and Alaska Natives. }\end{array}$ \\
\hline $\begin{array}{l}\text { OELA } \\
\text { United States Department of } \\
\text { Education: The Newcomer } \\
\text { Toolkit } \\
\text { https:/www2.ed.gov/about/offices/list } \\
\text { loela/newcomers- } \\
\text { toolkit/ncomertoolkit.pdf }\end{array}$ & $\begin{array}{l}\text { The Newcomer Tool Kit provides (I) a discussion of } \\
\text { topics relevant to understanding, supporting, and } \\
\text { engaging newcomer students and their families; }(2) \text { tools, } \\
\text { strategies, and examples of classroom and schoolwide } \\
\text { practices in action, along with chapter-specific } \\
\text { professional learning activities for use in staff meetings or } \\
\text { professional learning communities; and (3) selected } \\
\text { resources for further information and assistance. }\end{array}$ \\
\hline
\end{tabular}




\begin{tabular}{|l|l|}
\hline \multicolumn{2}{|l|}{$\begin{array}{l}\text { Table AI. Equitable, Coherent, and Sustainable Systems - Resources to Support } \\
\text { English Learner Master Plan Development }\end{array}$} \\
\hline Resource & Summary \\
\hline $\begin{array}{l}\text { U.S. Department of Education: } \\
\text { English Learner Toolkit } \\
\text { https://www.ncela.ed.gov/english- }\end{array}$ & $\begin{array}{l}\text { Published by OELA, the English Learner Tool Kit (now } \\
\text { updated to align with ESSA) helps state and local } \\
\text { education agencies help English learners (ELs) by fulfilling } \\
\text { these obligations. The Toolkit has I0 chapters (one for } \\
\text { each section of the DCL), and contains an overview, } \\
\text { sample tools, and resources. }\end{array}$ \\
\hline
\end{tabular}

\section{EXAMPLES}

These examples are drawn from six districts across the state and exemplify promising approaches to detailing equitable education local policies for Multilingual and English learner students. Together with the resources in Appendix I, the examples are intended to support LEA team's development of an EL Master Plan focused on the first of four goals outlined in our Playbook which are: (I) Equitable, Coherent, and Sustainable Systems (2) Equity-driven Processes, Research-based Programs, and Practices (3) Family-Community Engagement; and (4) Accountability.

Goal I: Equitable, Coherent, and Sustainable Systems of the EL Master Plan includes 4 key components: (a) Commitment and Purpose; (b) Responding to Diverse Learners; (c) Program Options; and (d) Staffing. To reference content criteria for each of these components, see Step 3: Chapter Analysis, Reflection, and Evaluation (CARE) Tool in this Playbook.

We acknowledge and appreciate the leadership, commitment, and vision for excellence and equity for Multilingual and English Learner students exhibited by the following districts highlighted in this publication:

- Burbank Unified School District Master Plan for English Learners (2021-24) https://www.burbankusd.org/Page/2186

- Los Angeles Unified School District 2018 Master Plan for English Learners and Standard English Learners (2018) https://achieve.lausd.net/cms/lib/CA01000043/Centricity/domain/22/el\%20sel\%20master\%20plan/20I8\%20 Master\%20Plan\%20for\%20EL\%20and\%20SEL.pdf

- Mountain View School District Master Plan for English Learners (2020) Permission granted to include examples; Link not yet available on district website.

- Novato Unified School District English Learner Master Plan - Engage Empower Inspire towards Biliteracy! (2019/20) https://nusd.org/wp-content/uploads/2020/08/NUSD-English-Learner-Master-Plan-2019-20-WebsiteGoogle-Docs.pdf

- Oakland Unified School District's ELL Master Plan (2016) https://www.ousd.org/Page//7073

- Oxnard School District Master Plan for Services to English Learners (2019) https://www.oxnardsd.org/site/handlers/filedownload.ashx?moduleinstanceid=1262| \&dataid=10290\&FileN ame=ELPM\%20English\%202019\%20Final.pdf 
Figure Al.I Commitment and Purpose: Introduction \& Guiding Principles - Los Angeles Unified School District 2018 Master Plan for English Learners and Standard English Learners (2018, pages 23)

\title{
Introduction
}

\begin{abstract}
Mission
Embracing our diversity to educate L.A.'s youth, ensure academic achievement, and empower tomorrow's leaders. We are L.A. Unified.
\end{abstract}

\section{Vision}

L.A. Unified will be a progressive global leader in education, providing a dynamic and inspiring learning experience where all students graduate ready for success.

\section{The Mission and Vision for Language Education in L.A. Unified}

L.A. Unified is proud to provide the 2018 Master Plan for English Learners (ELs) and Standard English Learners (SELs). L.A. Unified is committed to increasing personalized learning experiences that begin with students' linguistic and cultural strengths. Through the expansion of school pathways, up to and including dual language education (DLE) and academic English Mastery Program Accelerated Academies, students acquire the academic language necessary to be college and career ready.

This plan lays out the District's vision and mission for educating our culturally and linguistically diverse students, including increasing DLE programming to provide opportunities for all students in the District to become bilingual and biliterate. Although this document is focused on the education of ELs and SELs, the vision for language education in the District is that all students will graduate from L.A. Unified as bilingual and biliterate.

Join us in envisioning and imagining that every single student feels as though their language matters, their culture matters, that they matter. Picture a future where L.A. students are prepared for $21^{\text {st }}$ century jobs, where our students lead the way because they have an impressive suite of skills and knowledge, excellent academic achievement across the spectrum of coursework, and full bilingualism and biliteracy. L.A. Unified graduates who receive the Seal of Biliteracy exemplify this future. In the current context, we can't afford to envision any other

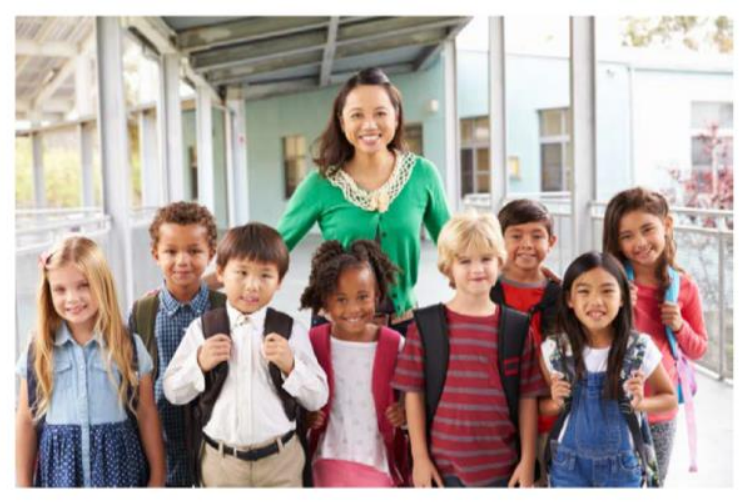
future. 


\section{Guiding Principles for Educating ELs and SELs}

These guiding principles were created as a collaborative effort by the Multilingual and Multicultural Education Department (MMED), Access, Equity and Acceleration, and members of the Master Plan Ad Hoc Working Group, with input from additional stakeholders.

1. Assets-based Education: Educators foster an assets-oriented mindset by knowing, valuing, and affirming their own, students', and families' cultures and languages, empowering students' voices, and cultivating a joy of learning.

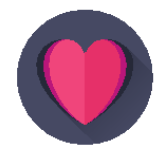

2. Bilingualism and Biliteracy: Students have opportunities to learn language skills in two or more languages, including speaking, writing, reading, and listening. Educators promote students' metacognitive skills, allowing them to make the appropriate language choices based on situational awareness. These skills support future language development, content learning, and postsecondary success to benefit their community and society.

3. Sociocultural Competence: There is an affirming classroom and school culture where staff, students, and families foster positive attitudes among students regarding both their own and others' diverse and complex cultural and linguistic identities.

4. Rigorous Academics for All: Language learners engage in intellectually rigorous and developmentally appropriate learning experiences that promote high levels of proficiency in English and another language, including academic language, as well as academic achievement across the curriculum.

5. Alignment and Articulation: Language learners experience a coherent, articulated, and aligned set of practices and pathways across contexts, starting in early childhood, through reclassification and graduation, in preparation for college and careers in the $21^{\text {st }}$ century.
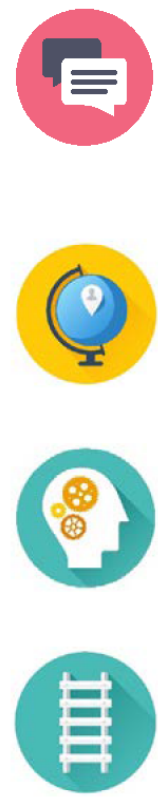

6. Systemic Support: Leaders and educators across all levels of the school system are provided integrated professional development. They share responsibility for educating and monitoring the progress of language learners, are accountable and responsive to the needs of diverse learners, and ensure fiscal investments are equity-oriented and research-based.

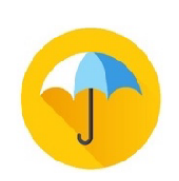


Figure AI.2. Commitment and Purpose: Introduction - Oakland Unified School District's ELL Master Plan (2016, page 6)

\section{INTRODUCTION TO ELL MASTER PLAN}

\section{INTRODUCTION}

"Language is learned, not because we want to talk or read or write about language, but because we want to talk and read and write about the world..."

\section{- Courtney Cazden, Professor Emerita,} Harvard Graduate School of Education

This English Language Learner Master Plan, originally adopted by the OUSD Board of Education in the fall of 2016, and newly revised in the spring of 2019, is designed to put into practice the idea that language learning and content learning are most powerful when they happen together. This concept is at the heart of the California ELD Standards and California ELA/ELD Framework. The pairing of English Language Arts and English Language Development in the title of the Framework itself --"ELA/ELD"--makes a clear reference to the fact that language skills teaching is not intended to be isolated from meaning-making and engagement with the world.

Our vision for English Language Learner (ELL) success certainly includes mastery of language skills. But the ultimate goal for ELLs is joyful and fulfilling participation in the community and the world, a life blessed with the gift of investigation and discovery, hard work, challenge, success, belonging and purpose. It is precisely by working towards this goal in our schools and communities that ELLs will have the most powerful opportunities to use, develop and master rich and complex language.
This document makes clear our critical legal obligations to ELLs, but we are also proud to point out that OUSD educators are less interested in mere compliance with law than in doing whatever is necessary to ensure our ELLs are college, career and community ready.

That is why this ELL Master Plan describes legal mandates but goes even further, providing a comprehensive framework for powerful practices for ELL instruction and services. It is intended as a reference document for all stakeholders in the District, especially site leaders. The online version of the document is full of links that take the reader to more detailed and in-depth information. Site leaders and other stakeholders can get essentials from the main document and deeper understanding from the links.

We hope you share our excitement as we continue this new chapter to accelerate ELL achievement, and we hope that this newly revised ELL Master Plan is a robust resource for guidance now and in the years ahead. 
Figure A I.3. Commitment and Purpose: Message from the Superintendent - Oxnard School District Master Plan for Services to English Learners (2019, pages 7 and 8)

Oxnard School District English Learner Master PIan - Chapter 1 |page 7

\section{Chapter 1: Superintendent's Message, English Learner Master Plan Goals, Mission, Vision, and Guiding Principles}

\section{Overview}

This chapter includes a message from the Superintendent and identifies the district's mission, vision, goals and guiding principles that are reflected in the Oxnard English Learner Master Plan. It also provides the purpose of the plan, collaborative development processes, and expectations for district-wide implementation.

\section{Message from the Superintendent}

It is our commitment to serve all children in our community and ensure successful support along their educational experience. Particularly, it is imperative to serve our English Learner students (ELs) and develop systems of support to achieve their reclassification status and expected goals.

In addition to helping our ELs acquire academic literacy, we are preparing them to navigate college, the job market and to become global citizens. It is our duty and obligation to do whatever we can to help our students connect learning with real life and emphasize the three types of 21 st Century Skills that prepare students to succeed in the informational age. The three types of skills and abilities are listed below.

\begin{tabular}{l|l|l}
\multicolumn{1}{c|}{ Learning Skills } & \multicolumn{1}{c|}{ Literacy Skills } & \multicolumn{1}{c}{ Life Skills } \\
\hline - Critical Thinking & - Information Literacy & - Flexibility \\
- Creative Thinking & - Media Literacy & - Initiative \\
- Communicating & - Technology Literacy & - Social Skills \\
& & - Productivity \\
\hline
\end{tabular}

https://k12.thoughtfullearning.com/FAQ/what-are-21st-century-skills

Chapter 1: Superintendent's Message, Goals of EL Master Plan - Mission, Vision and Guiding Principles 
The main drive of the Oxnard English Learner Master Plan is to provide educators with critical information related to the linguistic and educational needs of EL students, as well as the legal requirements for serving these students. Recognizing that ELs bring a wealth of knowledge and talent that will benefit our Oxnard community, we expect that this plan will be used to guide the implementation of best instructional practices for ELs and for driving systemic changes required to ensure the academic success of linguistically diverse learners. In order to ensure this, the plan uses as a guide the new policy for English Learners, The English Learner Roadmap, adopted by the State Board of Education in 2017. Oxnard School District understands that serving English Learners is a central responsibility of each and every educator and that our prosperity in California depends on the success of immigrants and their children.

The plan provides information on the following areas related to the linguistic and educational needs of English Learners:

- Understanding and meeting federal and state legal requirements

- Maintaining high-quality, standards-based language instruction leading to full academic engagement

- Acquiring 21 st century skills in curriculum and instruction

- Reporting and using data to manage instruction

- Monitoring and evaluation of program implementation

- Valuing, honoring, and embracing native heritage and cultural assets

- Engaging, informing and supporting the family and community

Our educators work tirelessly to make sure the needs of ELs are met; their experience, expertise, and understanding of the specific needs of ELs are our priority. Our goal is to support them in providing the best instruction possible for students, and in meeting and exceeding the policies, procedures, and compliance items addressed in this document, in order to ensure continued success for English Learners in school and in life.

In order to address the ever-changing and expanding needs of English Learners, we will review and update this document annually.

Chapter 1: Superintendent's Message, Goals of EL Master Plan - Mission, Vision and Guiding Principles 
Figure AI.4. Responding to Diverse Learners: Initial Identification and Placement Process Chart - Mountain View School District Master Plan for English Learners (2019-20, page 12)

Figure 1.1 Procedure for First Time Enrollment in a CA School

\section{INITIAL LANGUAGE PROFICIENCY ASSESSMENT, IDENTIFICATION AND \\ PLACEMENT PROCESS}

Flow Chart

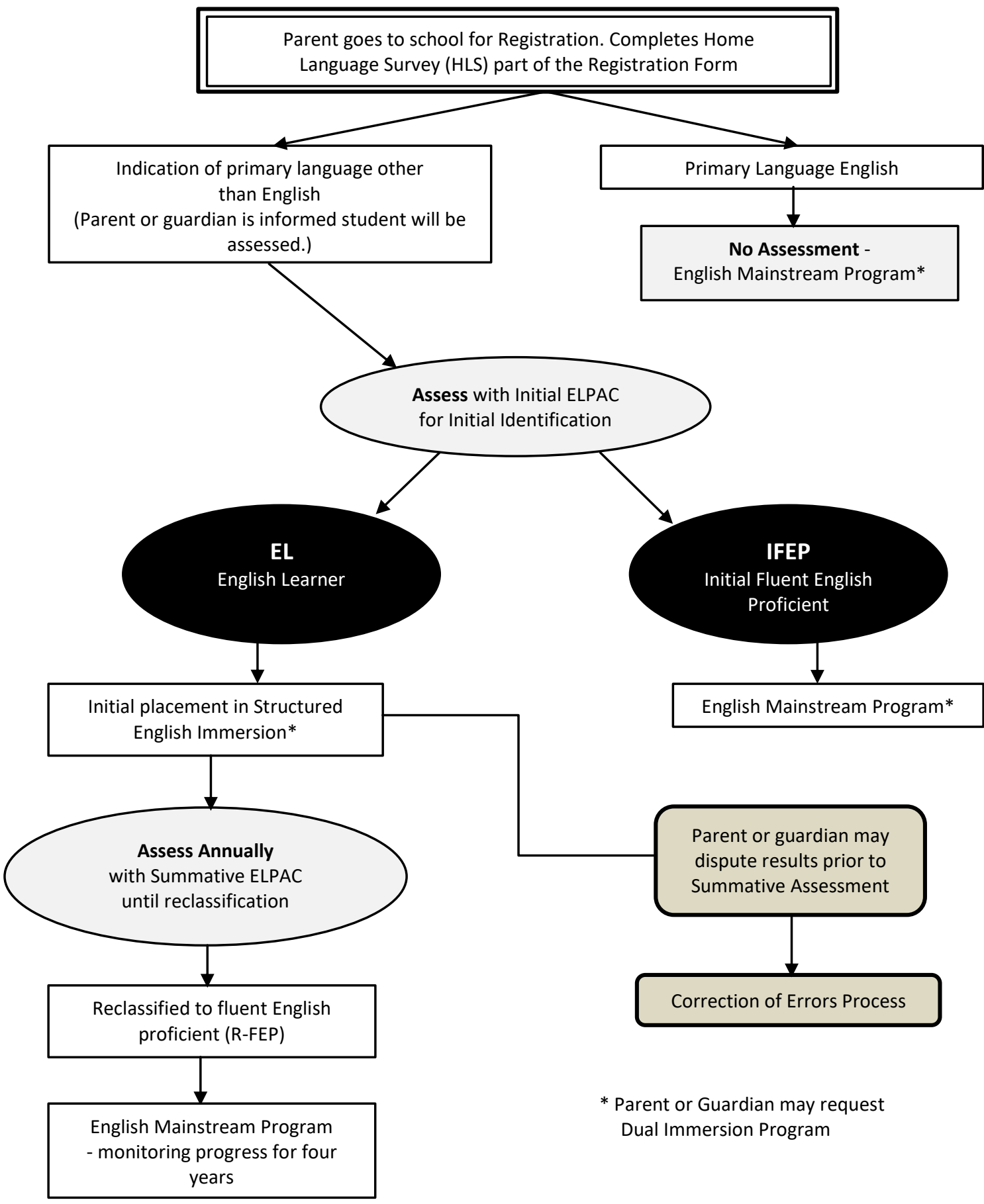


Figure A I.5. Instructional Program Options Flow Chart - Mountain View School District Master Plan for English Learners (2019-20, page 22)

Figure 1.5 MVSD Instructional Program Options Flow Chart

\begin{tabular}{|c|c|c|c|}
\hline \multicolumn{4}{|c|}{ Mountain View School District English Learner Program Flow Chart } \\
\hline Initial & Testing & Program Options & Ongoing Monitoring \\
\hline $\begin{array}{l}\text { Home Language Survey } \\
\text { (HLS) } \\
\text { Any parent who } \\
\text { answers the first three } \\
\text { questions with a } \\
\text { language other than } \\
\text { English will trigger } \\
\text { language testing in } \\
\text { English and the primary } \\
\text { language }\end{array}$ & $\begin{array}{l}\text { English Only (EO) } \\
\text { If the HLS states only } \\
\text { English on the first } \\
\text { three questions - } \\
\text { No Initial ELPAC } \\
\text { testing is required }\end{array}$ & $\begin{array}{l}\text { Program 1 - Structured English } \\
\text { Immersion (SEI) } \\
\text { This is the default program for all } \\
\text { English learners. If the student is } \\
\text { Novice EL or Intermediate EL, the } \\
\text { student is placed in SEl. This } \\
\text { option is for students with less than } \\
\text { reasonable fluency in English. } \\
\text { Instruction includes Integrated and } \\
\text { Designated English Language } \\
\text { Development (ELD). Instruction } \\
\text { may include primary language } \\
\text { support. Teacher has CLAD/ } \\
\text { BCLAD or Bilingual certification. }\end{array}$ & $\begin{array}{l}\text { Students are expected to } \\
\text { make annual growth in } \\
\text { English on both ELPAC } \\
\text { and DORA Assessments in } \\
\text { order to be reclassified as } \\
\text { Fluent English Proficient } \\
\text { (RFEP). Ongoing } \\
\text { monitoring is } \\
\text { documented using the } \\
\text { ELLevation EL Profile } \\
\text { Forms, DORA results, and } \\
\text { teacher recommendation }\end{array}$ \\
\hline $\begin{array}{l}\text { Parents may request } \\
\text { that their English } \\
\text { learner (EL) child be } \\
\text { placed in the Dual } \\
\text { Immersion Program at } \\
\text { any time, regardless of } \\
\text { the ELPAC scores and } \\
\text { Home Language } \\
\text { Survey }\end{array}$ & $\begin{array}{l}\text { ELPAC } \\
\text { Parent Notification - } \\
\text { Student will be tested }\end{array}$ & $\begin{array}{l}\text { Program } 2 \text { - English Language } \\
\text { Mainstream (M). This is the } \\
\text { default program for English only } \\
\text { and IFEP students. Parents may } \\
\text { request placement in Mainstream } \\
\text { setting regardless of the ELPAC } \\
\text { score. Instruction must be } \\
\text { overwhelmingly in English. } \\
\text { Teacher has CLAD certification. }\end{array}$ & \multirow[t]{2}{*}{$\begin{array}{l}\text { Reclassification Criteria } \\
\text { - Please see } \\
\text { Reclassification Matrix } \\
\text { for Criteria (Appendix E) } \\
\text { - Teacher } \\
\text { recommendation } \\
\text { - Parent approval } \\
\text { - Ongoing monitoring for } \\
4 \text { years }\end{array}$} \\
\hline \multirow{3}{*}{$\begin{array}{l}\text { English learner (EL) } \\
\text { students are placed in } \\
\text { programs designed to } \\
\text { develop reasonable } \\
\text { fluency in English and } \\
\text { to gain content } \\
\text { knowledge through the } \\
\text { use of methodologies } \\
\text { and materials designed } \\
\text { to meet their needs. }\end{array}$} & $\begin{array}{l}\text { before test is } \\
\text { administered }\end{array}$ & $\begin{array}{l}\text { Program } 3 \text { - Dual Language } \\
\text { Immersion (DLI) }\end{array}$ & \\
\hline & $\begin{array}{l}\text { ELPAC Initial } \\
\text { Assessment Levels: } \\
\text { - Novice English } \\
\text { learner } \\
\text { - Intermediate learner } \\
\text { - Initial Fluent } \\
\text { English Proficient } \\
\text { (IFEP) }\end{array}$ & $\begin{array}{l}\text { Program } 4 \text { - Newcomers }\left(4^{\text {th }}-8^{\text {th }}\right) \\
\text { English Learners at Novice level on } \\
\text { ELPAC, in US schools less than } \\
\text { one year. Provides intensive ELD } \\
\text { and primary language support. }\end{array}$ & \multirow[t]{2}{*}{$\begin{array}{l}\text { Plan for Long Term } \\
\text { English Learners (LTEL) } \\
\text { EL Students in US 5+ years } \\
\text { who are not making } \\
\text { adequate academic } \\
\text { progress, will be provided } \\
\text { appropriate program } \\
\text { placement and } \\
\text { intervention. }\end{array}$} \\
\hline & & $\begin{array}{l}\text { Teacher must have BCLAD or } \\
\text { Bilingual certification }\end{array}$ & \\
\hline $\begin{array}{l}\text { *Students who a } \\
\text { even if parent re }\end{array}$ & $\begin{array}{l}\text { ed English learner } \\
\text { nglish Mainstrean }\end{array}$ & $\begin{array}{l}\text { ontinue to be tested with ELP } \\
\text { Im placement. }\end{array}$ & receive EL services, \\
\hline
\end{tabular}




\title{
Figure A I.6. Program Options and Staffing: Newcomer Programs - Oxnard School District Master Plan for Services to English Learners (2019, pages 35-36)
}

\author{
Oxnard School District English Learner Master. Plan - Chapter 3 page 35
}

\section{Newcomer Programs: Grades 3-8}

Elementary newcomer students are assessed in the Enrollment Center to determine primary language proficiency. Those who demonstrate grade-level proficiency in Spanish may be placed into alternative bilingual programs based on parental option and program availability. The Newcomer Program provides newly arrived English Learners, who have been in the U.S. for two years or less, with a specialized environment where they receive an intensive English acquisition program while they learn about their new school environment, culture, and country. Through use of appropriate curriculum and methods, students are able to acquire basic comprehension and progress to the Emerging and Expanding levels of language proficiency, including academic language.

When forming classes for newcomers at the intermediate school level, it is important to group students by English fluency level for ELD and for core content classes whenever possible, taking into consideration students with minimal or significantly interrupted schooling experiences. The Department of English Learner Services is responsible for support, coordination and guidance on the implementation of Newcomer Programs.

\begin{tabular}{|c|c|c|}
\hline Students Served & Program Components for ELs & Staffing \\
\hline $\begin{array}{l}\text { Recent arrivals to the } \\
\text { U.S. (within the past } \\
24 \text { months) with } \\
\text { English at ELPAC } \\
\text { Level 1. }\end{array}$ & $\begin{array}{l}\text { 1. ACCESS TO CORE AND ENGLISH } \\
\text { LANGUAGE DEVELOPMENT ELA/ELD } \\
\text { is the core of the academ ic day with systematic } \\
\text { instruction for a minimum of two hours. } \\
\text { 2. GROUPING Flexibility in grouping to enable } \\
\text { students to work at their English proficiency } \\
\text { level. } \\
\text { 3. PRIMARY LANGUAGE Primary language } \\
\text { support as needed. } \\
\text { 4. ASSESSMENT Frequent assessment, data } \\
\text { review, analysis and reflection to provide the } \\
\text { optimal experience for each student. } \\
\text { 5. CULTURAL PROFICIENCY Focus on } \\
\text { building cultural proficiency through use of } \\
\text { field trips and in-class presentations. } \\
\text { Exit readiness based upon growth using } \\
\text { assessment data. Average enrollment of } 12-18 \\
\text { months; maximum enrollment of two years with } \\
\text { some exceptions based on teacher } \\
\text { recommendation and ELS department approval. }\end{array}$ & $\begin{array}{l}\text { Multiple Subject Teaching } \\
\text { Credential. } \\
\text { English Learner } \\
\text { Authorization, CLAD (Cross- } \\
\text { cultural, Language and } \\
\text { Academic Development), SB } \\
\text { 395, SB 1969, or equivalent - } \\
\text { - Bilingual instructional } \\
\text { assistant to provide primary } \\
\text { language support when } \\
\text { needed } \\
\text { OR } \\
\text { Bilingual Authorization, } \\
\text { BCLAD (Bilingul Cross- } \\
\text { cultural, Language and } \\
\text { Academic Development), } \\
\text { Bilingual Certificate of } \\
\text { Competence (BCC), or } \\
\text { equivalent. }\end{array}$ \\
\hline
\end{tabular}




\begin{tabular}{|c|c|c|}
\hline Students Served & Program Components for ELs & Staffing \\
\hline $\begin{array}{l}\text { ELs with less than two } \\
\text { years in the U.S. }\end{array}$ & $\begin{array}{l}\text { 1. DAILY DESIGNATED ENGLISH LANGUAGE } \\
\text { DEVELOPMENT } \\
\text { Minimum } 1 \text { period daily of Designated ELD } \\
\text { instruction at the student's English Proficiency } \\
\text { level. }{ }^{5} \\
\text { 2. ACCESS TO CORE } \\
\text { a. PRIMARY LANGUAGE DEVELOPMENT: } \\
\text { Newcomer students who come with grade level } \\
\text { literacy in Spanish have the option of enrolling in } \\
\text { Spanish for Spanish Speakers, when available } \\
\text { and feasible. } \\
\text { b. INTEGRATED ENGLISH LANGUAGE } \\
\text { DEVELOPMENT } \\
\text { Newcomers participate in content area courses } \\
\text { that provide access to the core curriculum using } \\
\text { SDAIE instruction at their English proficiency } \\
\text { level through integrated English Language } \\
\text { Development. Additionally, they may participate } \\
\text { in specific coursework that provides foundational } \\
\text { knowledge of U.S. and California history, culture } \\
\text { and schooling. } \\
\text { GROUPING Students grouped by English } \\
\text { 1. } \\
\text { language proficiency, with access to grade level } \\
\text { core when appropriate. } \\
\text { U.S. TRANSITION CURRICULUM Focus on } \\
\text { facilitating student familiarization with culture in } \\
\text { U.S. schools and adapting to school environments. } \\
\text { 5. ASSESSMENT Frequent assessment, data review, } \\
\text { analysis and reflection to provide the optimal } \\
\text { experience for each student. } \\
\text { Exit readiness based upon growth using assessment data } \\
\text { enrollment of } 12-18 \text { months; maximum enrollment of } \\
\text { two years with some exceptions based on teacher } \\
\text { recommendation and ELS department approval. }\end{array}$ & $\begin{array}{l}\text { Multiple or Single } \\
\text { Subject Teaching } \\
\text { Credential (Appropriate } \\
\text { subject matter } \\
\text { authorization). } \\
\text { English Learner } \\
\text { Authorization, CLAD } \\
\text { (Cross-cultural, } \\
\text { Language and } \\
\text { Academic } \\
\text { Development), SB 395, } \\
\text { SB 1969, or equivalent } \\
\text { - - Bilingual } \\
\text { instructional assistant } \\
\text { to provide primary } \\
\text { language support when } \\
\text { needed } \\
\text { OR } \\
\text { Bilingual } \\
\text { Authorization, BCLAD } \\
\text { (Bilingual Cross- } \\
\text { cultural, Language and } \\
\text { Academic } \\
\text { Development), } \\
\text { Bilingual Certificate of } \\
\text { Competence (BCC), or } \\
\text { equivalent. } \\
\end{array}$ \\
\hline \multicolumn{3}{|c|}{$\begin{array}{l}\text { Support Options for English Learners in Newcomer Programs: } \\
\text { - Tualler class sizes - optimal no more than } 25: 1 \\
\text { - } \text { Migrant Education support, if eligible } \\
\text { - Outreach Specialist } \\
\text { - Newcomer Academy site TOSA }\end{array}$} \\
\hline
\end{tabular}

${ }^{5}$ ELD groups consist of students at the same level, or "one level plus." 
Figure A 1.7. Figure A2. Program Options and Staffing: Dual Language - Oxnard School District Master Plan for Services to English Learners (2019, pages 43-44)

8 describes the components of the $50 / 50$ Dual Program, including elements of time, content ar on and the distribution on languages across the day.

\begin{tabular}{|c|c|c|c|c|}
\hline \multirow{8}{*}{$\begin{array}{l}\text { IN } \\
\text { AM } \\
\text { le } \\
v e l \\
n t)\end{array}$} & $\begin{array}{l}\text { INSTRUCTION IN PRIMARY } \\
\text { LANGUAGE }\end{array}$ & $\begin{array}{c}\text { DAILY } \\
\text { PERCENTAGE }\end{array}$ & INSTRUCTION IN ENGLISH & $\begin{array}{r}\text { DAILY } \\
\text { PERCENTA }\end{array}$ \\
\hline & $\begin{array}{l}\text { Spanish Language Arts } \\
\text { Spanish Language Development } \\
\text { History/Social Science } \\
\text { Number Corner }\end{array}$ & $50 \%$ & $\begin{array}{l}\text { Academic ELD } \\
\text { English Language Arts } \\
\text { Science } \\
\text { Math }\end{array}$ & $50 \%$ \\
\hline & $\begin{array}{l}\text { Spanish Language Arts } \\
\text { Spanish Language Development } \\
\text { Science } \\
\text { Number Corner }\end{array}$ & $50 \%$ & $\begin{array}{l}\text { Academic ELD } \\
\text { English Language Arts } \\
\text { History/Social Science } \\
\text { Math }\end{array}$ & $50 \%$ \\
\hline & $\begin{array}{l}\text { Spanish Language Arts } \\
\text { Spanish Language Development } \\
\text { History/Social Science } \\
\text { Number Corner }\end{array}$ & $50 \%$ & $\begin{array}{l}\text { Academic ELD } \\
\text { English Language Arts } \\
\text { Science } \\
\text { Math }\end{array}$ & $50 \%$ \\
\hline & $\begin{array}{l}\text { Spanish Language Arts } \\
\text { Spanish Language Development } \\
\text { Science } \\
\text { Number Corner }\end{array}$ & $50 \%$ & $\begin{array}{l}\text { Academic ELD } \\
\text { English Language Arts } \\
\text { History/Social Science } \\
\text { Math }\end{array}$ & $50 \%$ \\
\hline & $\begin{array}{l}\text { Spanish Language Arts } \\
\text { Spanish Language Development } \\
\text { History/Social Science } \\
\text { Number Corner }\end{array}$ & $50 \%$ & $\begin{array}{l}\text { Academic ELD } \\
\text { English Language Arts } \\
\text { Science } \\
\text { Math }\end{array}$ & $50 \%$ \\
\hline & $\begin{array}{l}\text { Spanish Language Arts } \\
\text { Spanish Language Development } \\
\text { Science } \\
\text { Number Corner }\end{array}$ & $50 \%$ & $\begin{array}{l}\text { Academic ELD } \\
\text { English Language Arts } \\
\text { Math } \\
\text { History/Social Science }\end{array}$ & $50 \%$ \\
\hline & $\begin{array}{l}\text { Spanish Literature } \\
\text { History/Social Science }\end{array}$ & $40 \%$ & $\begin{array}{l}\text { English Language Arts } \\
\text { Science }\end{array}$ & $60 \%$ \\
\hline
\end{tabular}


Figure AI.8- Staffing - Oxnard School District Master Plan for Services to English Learners (2019, page 94)

Oxnard School District ensures that all administrators or additional teaching personnel whose assignment includes English Learners also hold appropriate certification to provide necessary instructional services to English Learners.

\section{EL Roadmap Principle $3 A \sim($ Leadership)}

Teacher hiring and placement decisions are based on student and program need, including English Learner enrollment data, and other relevant factors. The district's collective bargaining agreements are adhered to in making all staffing decisions. Whenever open teaching positions require Bilingual or English Learner Authorization, the district Human Resources staff actively recruits and hires teachers who are fully certified to fill such positions.

\begin{tabular}{|c|c|c|}
\hline Instructional Program & Grade Level(s) & Proper Authorization \\
\hline Structured English Immersion & $\mathrm{TK}-8$ & $\begin{array}{l}\text { Bilingual Authorization/BCLAD or equivalent } \\
\text { OR } \\
\text { EL Authorization /CLAD or equivalent with bilingual paraeducator to } \\
\text { provide primary language support when needed }\end{array}$ \\
\hline English Language Mainstream & $6-8$ & $\begin{array}{l}\text { Bilingual Authorization/BCLAD or equivalent } \\
\text { OR } \\
\text { EL Authorization /CLAD or equivalent with bilingual paraeducator to } \\
\text { provide primary language support when needed }\end{array}$ \\
\hline Transitional Bilingual Education & $2-3$ & Bilingual Authorization/BCLAD or equivalent \\
\hline Dual Language & $\mathrm{TK}-8$ & EL Authorization /CLAD or equivalent (for English teachers) \\
\hline Newcomer & $3-5$ and $6-8$ & $\begin{array}{l}\text { Bilingual Authorization/BCLAD or equivalent } \\
\text { OR } \\
\text { EL Authorization /CLAD or equivalent with bilingual paraeducator to } \\
\text { provide primary language support when needed }\end{array}$ \\
\hline
\end{tabular}

Chapter 7: Staffing and Professional Learning 
Figure AI.9. Staffing - Novato Unified School District English Learner Master Plan - Engage Empower Inspire towards Biliteracy! (2019-20, page 45)

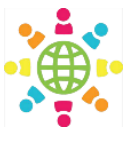

Novato Unified School District

English Learner Master Plan

with BCLAD emphasis, BCLAD, Bilingual Certificate of Competence (BCC) University or District Internship Credential with BCLAD emphasis to fill all openings, the teachers who are assigned to classrooms with ELs must enroll in approved training programs to secure the necessary authorizations.

\section{Hiring Priorities and Procedures}

Aggressive recruitment efforts are undertaken, internally and externally, until all positions are filled with qualified candidates:

- Priority 1: Highest priority is placed on the hiring of BCLAD or equivalent teachers and their subsequent placement in primary language and dual language classrooms.

- Priority 2: The second priority are bilingual teachers who lack BCLAD authorization and who may be assigned to designated bilingual classrooms as an "actively pursuing" BCLAD credentialed teacher.

- Priority 3: The third priority is CLAD or equivalent certified teachers. These teachers are placed in mainstream classrooms with ELs. They may receive support from bilingual paraprofessionals who use the primary language to clarify, explain, motivate, and direct students.

- $\quad$ Priority 4: The fourth priority is for teachers who are in the process of obtaining a CLAD or equivalent credential.

\section{Administrative Staff}

To support the implementation of the EL programs and services at the sites, staffing of schools with administrators is completed in the following prioritized manner:

- Priority 1: Administrators with BCLAD credential and experience in working with EL students and programs.

- Priority 2: Administrators with CLAD credential and experience in working with ELL students and programs or who are receiving training on how to support ELL students and programs.

- Priority 3: Administrators in an approved California Commission on Teaching Credentialing (CCTC) internship program who possess a BCLAD or CLAD credential and with experience in working with ELL students and programs

\section{Appropriate Use of Certificated and Bilingual Professionals}

The Superintendent or designee is responsible to work with District Administration to properly plan, structure, and organize certificated professional staff to meet the needs of English Learners' instructional needs. To effectively coordinate the (1) Identification, assessment and program placement; (2) Instructional Programs; (3) Monitoring of student progress and 


\section{APPENDIX 2. EQUITY-DRIVEN PROCESSES, RESEARCH-BASED PROGRAMS}

AND PRACTICES

These resources support the development of an EL Master Plan focused on the second of four goals outlined in our Playbook which are: (I) Equitable, Coherent, and Sustainable Systems (2) Equity-driven Processes, Research-based Programs, and Practices (3) FamilyCommunity Engagement; and (4) Accountability.

Goal 2: Equity-driven Processes, Research-based Programs and Practices can be written as a series of chapters, or any combination of chapters and includes 3 key components:

- Access to Core Curriculum

- English Language Development

- Professional Learning

RESOURCES

\begin{tabular}{|c|c|}
\hline Resource & Summary \\
\hline $\begin{array}{l}\text { California English } \\
\text { Language/English Language } \\
\text { Development Framework } \\
(20 \mid 4) \\
\text { https://www.cde.ca.gov/ci/rl/cf/ela } \\
\text { eldfrmwrksbeadopted.asp }\end{array}$ & $\begin{array}{l}\text { The CA ELA/ELD Framework provides guidance to support } \\
\text { students to be college/career ready and to address the } \\
\text { various language needs of California's diverse student } \\
\text { population. It highlights critical skills and expectations in } \\
\text { English language arts necessary to develop students' literacy } \\
\text { in the twenty-first century aligned to the ELA/ELD standards } \\
\text { and provides guidance to educators to help build new depth } \\
\text { of knowledge to promote literacy through critical thinking } \\
\text { and problem solving, collaboration, and communication on a } \\
\text { range of topics. }\end{array}$ \\
\hline $\begin{array}{l}\text { Designated and Integrated } \\
\text { ELD - the Left and Right } \\
\text { Hand of ELD Instruction } \\
\text { https://dataworks- } \\
\text { ed.com/blog/2020/05/designate } \\
\text { d-and-integrated-eld- } \\
\text { instruction/ }\end{array}$ & $\begin{array}{l}\text { Based on the CA ELA/ELD framework, this article explores } \\
\text { key differences between integrated and designated ELD. It } \\
\text { also provides a series of vignettes that will be helpful as } \\
\text { educators select and design the elements for meaningful } \\
\text { DELD instruction. Other resources such as the English } \\
\text { Learner Instructional Approaches and Modeling the } \\
\text { Metacognitive Strategies for English learners, will support } \\
\text { educators as they frame the development of Designated ELD } \\
\text { instruction in connection with digital tools for distance } \\
\text { learning. }\end{array}$ \\
\hline $\begin{array}{l}\text { English Learner Toolkit of } \\
\text { Strategies } \\
\text { https://ccsesa.org/?wpfb_dl=7006 }\end{array}$ & $\begin{array}{l}\text { This Toolkit is designed for } \mathrm{K}-\mathrm{I} 2 \text { educators to support } \\
\text { instruction for both Integrated and Designated English } \\
\text { Development to prepare ELs for literacy in the } 2 \text { Ist Century. }\end{array}$ \\
\hline
\end{tabular}




\begin{tabular}{|c|c|}
\hline Resource & Summary \\
\hline $\begin{array}{l}\text { Implementing the Common } \\
\text { Core for English learners } \\
\text { http://www.cal.org/siop/pdfs/bri } \\
\text { efs/implementing-common- } \\
\text { core-for-english-learners.pdf }\end{array}$ & $\begin{array}{l}\text { This document addresses five key questions related to } \\
\text { effective implementation of the CCSS with English learners. } \\
\text { The topics addressed represent a synthesis of the questions } \\
\text { and concerns raised by educators participating in the Center } \\
\text { for Applied Linguistics professional development activities. } \\
\text { Included under each question are ideas for classroom } \\
\text { strategies to support the implementation of the CCSS. }\end{array}$ \\
\hline $\begin{array}{l}\text { Improving Education for } \\
\text { Multilingual and English } \\
\text { Learner Students: Research to } \\
\text { Practice - Chapters } 5 \text { and 6: } \\
\text { ELD Instruction in } \\
\text { Elementary and Secondary } \\
\text { grades } \\
\text { https://www.cde.ca.gov/sp/el/er/d } \\
\text { ocuments/mleleducationch5.pdf } \\
\text { and } \\
\text { https://www.cde.ca.gov/sp/el/er/d } \\
\text { ocuments/mleleducationch6.pdf }\end{array}$ & $\begin{array}{l}\text { Chapters } 5 \text { and } 6 \text { of this } 2020 \text { California Department of } \\
\text { Education publication present current evidence-based } \\
\text { pedagogy and practices in the areas of English language } \\
\text { development. These chapters are intended to assist in the } \\
\text { instruction of Integrated and Designated ELD in the } \\
\text { Elementary Grades and Content and Language Instruction in } \\
\text { the Secondary Grades, respectively. }\end{array}$ \\
\hline $\begin{array}{l}\text { NASEM Report } \\
\text { Promoting the Educational } \\
\text { Success of Children and Youth } \\
\text { Learning English: Promising } \\
\text { Futures (20I7) } \\
\text { Chapter 6: The } \\
\text { Development of English } \\
\text { Language Proficiency in } \\
\text { Grades K-I } 2 \\
\text { https://www.nap.edu/read/246 } \\
77 / \text { chapter/8 }\end{array}$ & $\begin{array}{l}\text { Chapter } 6 \text { of this National Academies of Science, } \\
\text { Engineering and Medicine (NASEM) report focuses on the } \\
\text { development of English proficiency by reviewing the research } \\
\text { on time required to achieve proficiency, reclassification, age } \\
\text { and English proficiency at school entry. It also offers and } \\
\text { analysis of the research on primary language loss and } \\
\text { retention and cross-linguistic factors. }\end{array}$ \\
\hline $\begin{array}{l}\text { Chapter 8: Promising and } \\
\text { Effective Practices for } \\
\text { English learners in Grades } \\
\text { PreK-I } 2 \\
\text { https://www.nap.edu/read/24677/ } \\
\text { chapter/I\#chapter08_pz|4-36 I }\end{array}$ & $\begin{array}{l}\text { Chapter } 8 \text { of this National Academies of Science, } \\
\text { Engineering and Medicine (NASEM) report reviews promising } \\
\text { and effective practices for English learners during Pre-K to } \\
\text { grade } 5 \text {, middle school years (grades 6-8) and grades } 9-12 \text {. }\end{array}$ \\
\hline
\end{tabular}




\section{EXAMPLES}

These examples are drawn from six districts across the state and exemplify promising approaches to detailing equitable education local policies for Multilingual and English learner students. Together with the resources in Appendix 2, the examples are intended to support LEA team's development of an EL Master Plan focused on the second of four goals outlined in our Playbook which are: (I) Equitable, Coherent, and Sustainable Systems (2) Equity-driven Processes, Research-based Programs, and Practices (3) Family-Community Engagement; and (4) Accountability.

Goal 2: Equity-driven Processes, Research-based Programs and Practices of the EL Master Plan includes 3 key components: (a) Access to Core Curriculum; (b) English Language

Development; and (c) Professional Learning. To reference content criteria for each of these components, see Step 3: Chapter Analysis, Reflection, and Evaluation (CARE) Tool in this Playbook.

We acknowledge and appreciate the leadership, commitment, and vision for excellence and equity for Multilingual and English Learner students exhibited by the following districts highlighted in this publication:

- Burbank Unified School District Master Plan for English Learners (202I-24) https://www.burbankusd.org/Page/2186

- Los Angeles Unified School District 2018 Master Plan for English Learners and Standard English Learners (2018) https://achieve.lausd.net/cms/lib/CA01000043/Centricity/domain/22/el\%20sel\%20master\%20plan/2018\%20 Master\%20Plan\%20for\%20EL\%20and\%20SEL.pdf

- Mountain View School District Master Plan for English Learners (2020) Permission granted to include examples; Link not yet available on district website.

- Novato Unified School District English Learner Master Plan - Engage Empower Inspire towards Biliteracy! (2019/20) https://nusd.org/wp-content/uploads/2020/08/NUSD-English-Learner-Master-Plan-2019-20-WebsiteGoogle-Docs.pdf

- Oakland Unified School District's ELL Master Plan (2016) https://www.ousd.org/Page//7073

- Oxnard School District Master Plan for Services to English Learners (2019) https://www.oxnardsd.org/site/handlers/filedownload.ashx?moduleinstanceid=1262 | \&dataid=10290\&FileN ame=ELPM\%20English\%202019\%20Final.pdf 
Figure A2. I. Equity-driven Processes, Research-based Programs and Practices: The Art and Science of Teaching for English Learners - Los Angeles Unified School District 2018 Master Plan for English Learners and Standard English Learners (2018, p. 74)

L.A. Unified 2018 Master Plan for English Learners and Standard English Learners

\section{The Art and Science of Teaching for English Learners}

Educators should follow the cycle depicted in Figure 24, The Art and Science of Teaching for ELs, for implementation of effective instruction that accounts for the information contained in this chapter. Figure 24 was developed to provide a visual representation of all key considerations for effective EL instruction addressed in this chapter.

Figure 24: The Art and Science of Teaching for ELs

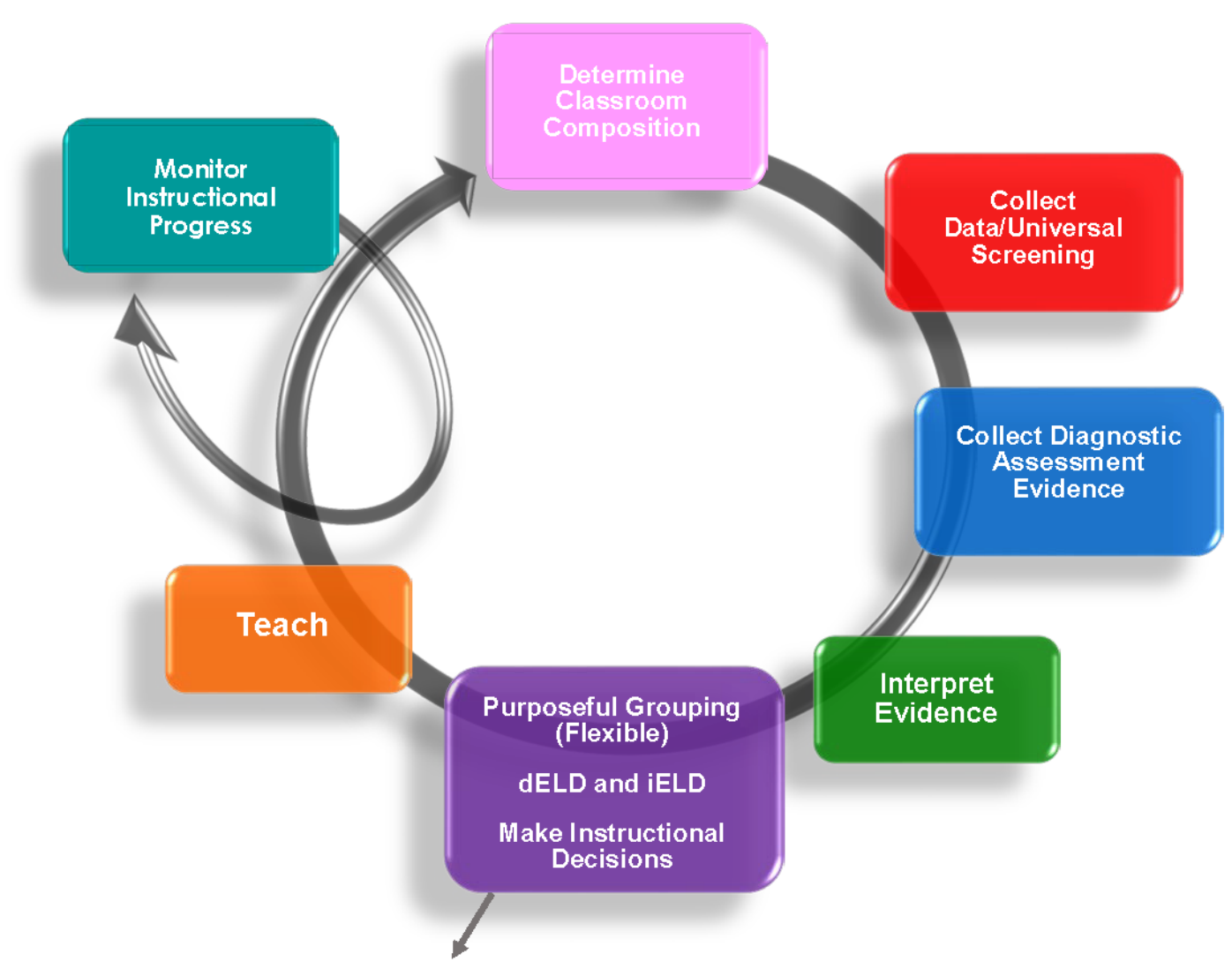

Differentiation for ELs

Goals: Develop BOTH

language and content 
Figure A2.2. Equity-driven Processes, Research-based Programs and Practices: Guiding Questions for Providing Effective English Learner Instruction - Los Angeles Unified School District 2018 Master Plan for English Learners and Standard English Learners (2018, p. 75)

L.A. Unified 2018 Master Plan for English Learners and Standard English Learners

\section{Guiding Questions for Providing Effective English Learner Instruction}

The questions in Figure 25 should be considered when planning for effective instruction for ELs.

The following sections provide more information on each of these five questions.

Figure 25: Guiding Questions for Providing Effective EL Instruction

\section{Who are our EL students? \\ Consider: EL typologies, ages, proficiency levels, size of population}

\section{What are our instructional program options?}

Consider: Programming and placement based on EL typologies, parent requests, and available instructional program options

3. How do we determine classroom composition?

Consider: Student population, both homogeneous and

heterogeneous grouping, staffing, available program models

4. How do we flexibly group students for instruction?

Consider: Comprehensive ELD instruction, individual needs for

iELD (homogeneous and heterogenous) and dELD

(homogeneous)

5. How do we differentiate instruction to meet students' needs?

Consider: Formative assessments, ELD levels and progress 


\section{Figure A2.3 Equity-driven Processes, Research-based Programs and Practices : Instructional Programs for ELLs - Oakland Unified School District's ELL Master Plan (2016, page 23)}

\section{2 \\ INSTRUCTIONAL PROGRAMS FOR ELLS}

\section{INTRODUCTION AND GRAPHIC ORGANIZER}

OUSD's instructional programs for English Language Learners (ELLS) are the core of our mission to ensure ELLs are college, career and community ready. The purpose of our instructional programs is to teach ELLs to understand and use academic English proficiently and effectively while at the same time ensuring they have meaningful access to a high quality education and the opportunity to achieve their full academic potential. OUSD instructional programs for ELLs are:

- Clearly defined;

- Research based;

- Aligned with the rigor of the Common Core State Standards, New Generation Science Standards, California ELD Standards and California ELA/ELD Framework;

- Driven by the theory of action laid out in the Essential Practices for ELL Achievement:

- Designed to address the needs of each ELL subgroup;

- Strongly supported and resourced at the site, network and central office level;

- Effectively monitored.
In this chapter we:

- Describe the framework for ELL instruction known as Integrated ELD and Designated ELD;

- Provide guidance for the scheduling and implementation of Designated ELD;

- Describe the instructional programs that put the Integrated and Designated ELD framework into action for all ELL subgroups;

- Articulate minimum progress expectations for students enrolled in the instructional programs;

- Explain how we use the MTSS framework to monitor and support ELLs who are not meeting minimum progress expectations;

- Provide guidance on using an ELL's primary language as a learning resource;

- Outline the professional development that supports effective instruction for ELLs.

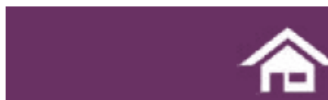

WHAT DO SCHOOL SITES NEED TO DO?

In order to provide robust instructional programs for ELLs, sites:

1. Provide instructional programs that address the needs of all ELL subgroups present at the site.

2. Implement the chosen instructional program(s) at the site with fidelity.

3. Provide robust Integrated ELD across the content areas aligned with the CA ELA/ELD Framework.

4. Provide daily Designated ELD to ELLs until they reclassify.

5. Provide ongoing professional learning on best practices in ELL instruction supported by central office, including ELLMA and Academics and Instructional Innovation.

6. Monitor ELL progress and effectiveness of instruction with both formative and summative assessments.

7. Use MTSS to ensure robust support of ELLs at the site. 
Figure A2.4. English Language Development : Mandatory Designated ELD Time - Oxnard School District Master Plan for Services to English Learners (2019, page 69)

\begin{tabular}{|c|c|}
\hline Grade & Required Daily Minutes of Designated ELD Instruction \\
\hline TK-K & 30 minutes per day \\
\hline $1-5$ & 45 minutes per day \\
\hline $6-8$ & $\begin{array}{l}\text { One period daily in addition to grade-level core English language arts for students } \\
\text { who are at ELPAC Emerging and Expanding Levels) } \\
\text { For ELPAC Bridging - Daily ELD, leveled and specialized according to students' } \\
\text { English proficiency level; ELD may be a designated part of their English } \\
\text { Language Arts class as well as through AVID Excel elective. }\end{array}$ \\
\hline $\begin{array}{c}\text { Newcomer Program } \\
3-5 \\
6-8\end{array}$ & $\begin{array}{l}\frac{\text { Grades } 3-5}{45 \text { minutes for } 2 \text { instructional blocks, including U.S. culture, history and }} \\
\text { schooling } \\
\text { *ELD is consistently implemented and designed to promote second language } \\
\text { acquisition of listening, speaking, reading and writing, as well as integrated } \\
\text { Grades } 6-8 \\
1 \text { period daily of Designated ELD instruction at the student's English proficiency } \\
\text { level }\end{array}$ \\
\hline
\end{tabular}

Figure A2.5 English Language Development: Designated ELD Course Sequence, Grades 6-8 Oxnard School District Master Plan for Services to English Learners (2019, page 7I)

\begin{tabular}{|c|c|c|}
\hline Newcomer & $\begin{array}{c}\text { Returning/Continuing Student } \\
\text { (Normative Progress) }\end{array}$ & $\begin{array}{l}\text { Long Term English Learner (LTEL) } \\
\text { and "At-Risk" of Becoming LTEL }\end{array}$ \\
\hline $\begin{array}{l}\text { ELPAC Emerging or Low Expanding } \\
\text { - } 1-2 \text { periods daily } \\
\text { - }\end{array}$ & $\begin{array}{l}\text { ELPAC Mid-Expanding } \\
\text { - } 1 \text { period Designated ELD daily } \\
\text { - Concurrent with ELA/Integrated } \\
\text { ELD }\end{array}$ & $\begin{array}{l}\text { ELPAC Mid-Expanding } \\
\text { - } 1 \text { period Designated ELD daily } \\
\text { - } \quad \text { Concurrent with ELA/Integrated ELD }\end{array}$ \\
\hline $\begin{array}{l}\text { ELPAC Low Expanding } \\
\text { - } \quad 1-2 \text { periods daily } \\
\text { No more than } 3 \text { years in U.S. } \\
\text { schools } \\
\text { - Replaces grade-level English course }\end{array}$ & $\begin{array}{l}\text { ELPAC High Expanding and Bridging } \\
\text { Daily ELD, leveled and specialized } \\
\text { according to students' English } \\
\text { proficiency level, may be a } \\
\text { designated part of their English } \\
\text { Language Arts class } \\
\text { Concurrent with ELA/Integrated } \\
\text { ELD }\end{array}$ & $\begin{array}{l}\text { ELPAC High Expanding and Bridging } \\
\text { Daily ELD, leveled and specialized } \\
\text { according to students' English proficiency } \\
\text { level, may be a designated part of their } \\
\text { English Language Arts class or AVID Excel } \\
\text { Specialized ELA course for LTELs } \\
\text { according to whether they are less than } 3 \\
\text { years below grade level or need further } \\
\text { development of academic oral language and } \\
\text { expository writing: } 1 \text { period }\end{array}$ \\
\hline
\end{tabular}




\section{Figure A2.6 English Language Development: LTEL Support - Academic Language Development Course Oakland Unified School District's ELL Master Plan (2016, pages 37-38)}

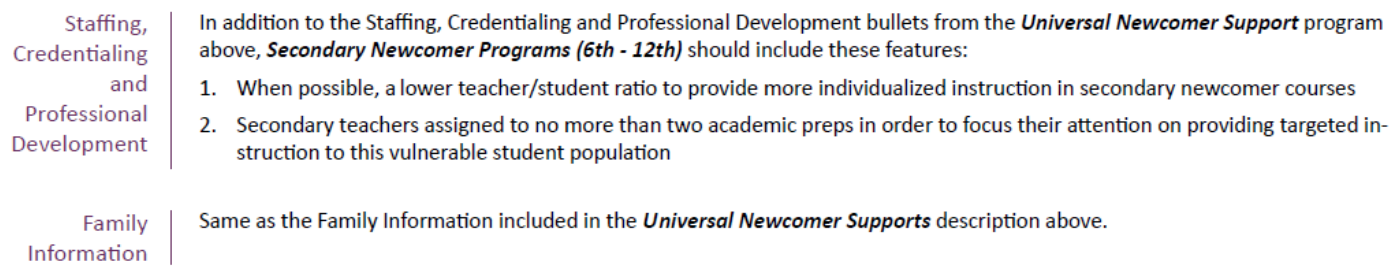

\section{LTEL SUPPORT: ACADEMIC LANGUAGE DEVELOPMENT COURSE (SECONDARY ONLY, LTELS AND AT-RISK ELLS)}

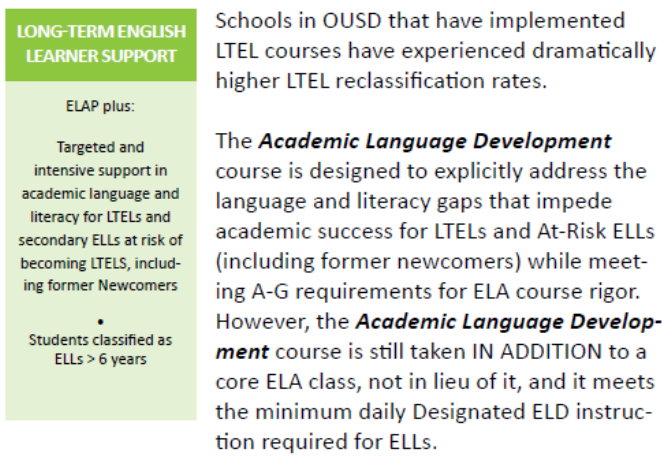

The course focuses on academic language and literacy development and emphasizes student engagement, student debate and discussion, expository text, goal setting, and At sites with more than empowering pedagogy. Writing from evidence, vocabulary becoming LTELS, an LTEL development, and reading of increasingly complex text and text-based academic discussions are key components. Please see the LTEL Course Handbook for more specific LTEL course features. At sites with more than 20 LTELs, or students at risk of becoming LTELs, including former newcomers, an LTEL course must be offered.

\section{FEATURES OF LTEL SUPPORT: ACADEMIC LANGUAGE DEVELOPMENT COURSE}

Students Served and Exit Criteria

1. Students are enrolled in the program if they have been ELLs for more than six years or if they are at-risk of becoming LTELs and have finished the other courses in the ELD course sequence. In order to fully access, with scaffolds, the course texts, it is recommended that these students achieve a score of at least 450 on the RI for grades 6 to 8 , and at least 700 for grades 9 to 12 . If they have not, students should also be supported with a reading intervention course, and this course should include the language development features that are standard for Integrated ELD across all content areas.

2. Students are exited from the program when they reclassify as Fluent English Proficient (RFEP). They may stay in the program during part or all of their four years of RFEP monitoring if the data demonstrates they are not making adequate progress as indicated by the RI and SBAC/IAB data.

Program $\mid$ In addition to the Program Components bullets from the ELAP instructional program above, the Academic Language Development Course should include these features:

1. The program is designed to explicitly address the language and literacy gaps that impede academic success for LTELs.

2. A smaller class size to reduce the student-teacher ratio when possible is recommended.

3. Site monitors progress throughout course using curriculum-embedded benchmark assessments.

4. Overall progress is monitored annually through ELPAC, RI and SBAC/IAB.

5. Curriculum emphasizes rich oral and written academic language development and work with complex text.

6. Instruction is designed to provide appropriate supports and scaffolds without undermining "productive struggle."

7. Student engagement is emphasized and encouraged through consistent instructional routines that emphasize structured speaking opportunities.

8. Goal-setting around language development and reclassification is emphasized

9. Each LTEL is assigned to a counselor, teacher or TSA to monitor progress across all content areas.

10. For LTELs with IEPs, clear articulation and consistent implementation of IEP language development goals is provided. 


\section{Figure A2.7. English Language Development: Secondary Course Placement - Burbank Unified School District Master Plan for English Learners (2021-24, page 25)}

\section{Table 4.3: Placement of English Learners in ELD Classes at the Secondary Level}

The following chart represents a profile of EL students at each of the proficiency levels, based on expected progress in acquiring English. Students are moved from level to level using these criteria as well as teacher judgment.

\begin{tabular}{|c|c|c|c|c|c|}
\hline & \multicolumn{5}{|c|}{ ELD Classes } \\
\hline & ELD 1 & ELD 2 & ELD 3 & ELD 4 or English $T$ & English T \\
\hline $\begin{array}{c}\text { Time in US } \\
\text { Schools }\end{array}$ & less than a year & $1-2$ years & $2-3$ years & $4-5$ years & 5 years or more \\
\hline ELPAC Overall & $\begin{array}{c}\text { Level } 1 \\
\text { or } \\
\text { Level } 2 \text { Low }\end{array}$ & Level 2 & $\begin{array}{l}\text { Level } 2 \text { High } \\
\text { or } \\
\text { Level } 3 \text { Low }\end{array}$ & Level 3 & $\begin{array}{l}\text { Level } 3 \text { High } \\
\text { or } \\
\text { Level } 4\end{array}$ \\
\hline SBAC-ELA & \multicolumn{3}{|c|}{ SBAC Score 1 or 2 in English Language Arts } & \multicolumn{2}{|c|}{ SBAC Score 2-4* in English Language Arts } \\
\hline Lexile Score & BR/0-200 & $150-650$ & $400-900$ & \multicolumn{2}{|c|}{$600-1000$} \\
\hline $\begin{array}{l}\text { Reading Grade } \\
\text { Level Equiv. } \\
\text { (GMRA or STAR) }\end{array}$ & \multicolumn{2}{|c|}{$\begin{array}{l}3 \mathrm{yrs} \text {. or more }{ }^{* *} \\
\text { below grade level }\end{array}$} & $\begin{array}{c}2-3 \text { years below grade } \\
\text { level }\end{array}$ & $\begin{array}{l}1-2 \text { years below } \\
\text { grade level }\end{array}$ & $\begin{array}{l}.5 \mathrm{yr} \text {. below / close to } \\
\text { grade level }\end{array}$ \\
\hline $\begin{array}{c}\text { Writing } \\
\text { Characteristics }\end{array}$ & $\begin{array}{l}\text { - May write } 1-2 \text { simple } \\
\text { sentences } \\
\text { - Uses simple present or } \\
\text { past tenses }\end{array}$ & $\begin{array}{l}\text { - May or may not fully address } \\
\text { the prompt } \\
\text { - Has } 3 \text { sentences in a mostly } \\
\text { logical sequence } \\
\text { - May have run-ons or fragments } \\
\text { - May be able to write } \\
\text { compound/complex sentences } \\
\text { - Errors don't interfere with } \\
\text { reader's understanding }\end{array}$ & $\begin{array}{l}\text { - Addresses prompt } \\
\text { Writes 2-3 simple } \\
\text { paragraphs with topic } \\
\text { sentences, details and } \\
\text { conclusion. } \\
\text { - Writes compound \& } \\
\text { complex sentences, } \\
\text { - Minor errors don't interere } \\
\text { with reader's understanding }\end{array}$ & \multicolumn{2}{|c|}{$\begin{array}{l}\text { - Addresses prompt clearly } \\
\text { Organizes essay appropriately (introduction, body, conclusion) } \\
\text { - Uses key ideas and some supporting details in the body of the } \\
\text { essay } \\
\text { Adequately develops plot, setting, and characters. } \\
\text { Can write } 3-4 \text { paragraph essays/stories. } \\
\text { Organines ideas and details in a logical structure utilizing } \\
\text { some transitions } \\
\text { Uses words appropriately, varies sentence structure. } \\
\text { Uses more complex vocabulary and detailed sentences }\end{array}$} \\
\hline Notes: & \multicolumn{3}{|c|}{$\begin{array}{l}\text { Generally, if a student has been schooled in the US since TK, Kinder or } 1^{\text {st }} \text { grade, } \\
\text { ELD } 1-3 \text { would not be the correct placement, even if his/her ELPAC scores would } \\
\text { indicate otherwise. He/she is considered to be a long-term EL and needs different } \\
\text { kind of instruction than ELD 1-3. }\end{array}$} & \multicolumn{2}{|c|}{$\begin{array}{c}\text { If a student has been in US schools since TK, K or } 1 \text {, } \\
\text { but is still } 2 \text { or more years below grade level, place } \\
\text { him/her in English (T) and recommend an additional } \\
\text { reading intervention class. Also, when } \\
\text { recommending intervention, document the dates of } \\
\text { previous SSTs. }\end{array}$} \\
\hline
\end{tabular}

*SBAC Score of 3 or 4 qualifies a student for reclassification. However, the student must also have a score of 4 overall on the ELPAC to be reclassified. So, even though they may have met or exceeded standards on the SBAC ELA, they cannot be reclassified until the ELPAC overall is a 4.

**The use of "or more" includes a very broad range. For example, a beginning level proficiency student who enters BUSD in grade 12 may be significantly more than 4 years below grade level in English reading.

25 | P a g e 
Figure A2.8. Professional Learning - Novato Unified School District English Learner Master Plan Engage Empower Inspire towards Biliteracy! (2019/20, page 46)

\section{Our Core Principles for Professional Learning}

It is imperative that all professional learning opportunities are focused on "learning and continuous improvement" in a safe and welcoming environment. Professional learning should address ways to support English Learners, socially, emotionally, and academically. Principles of "Adult Learning" must be evident in our approach. Below are core principles for professional learning:

1. Establish community agreements

2. Analyze data to make informed decisions

3. Provide clear expectations and outcomes

4. Utilize research and evidence-based practices

5. Build from prior knowledge, experiences and expertise of participants

6. Focus on and connect learning to culturally and linguistically responsive teaching and practices

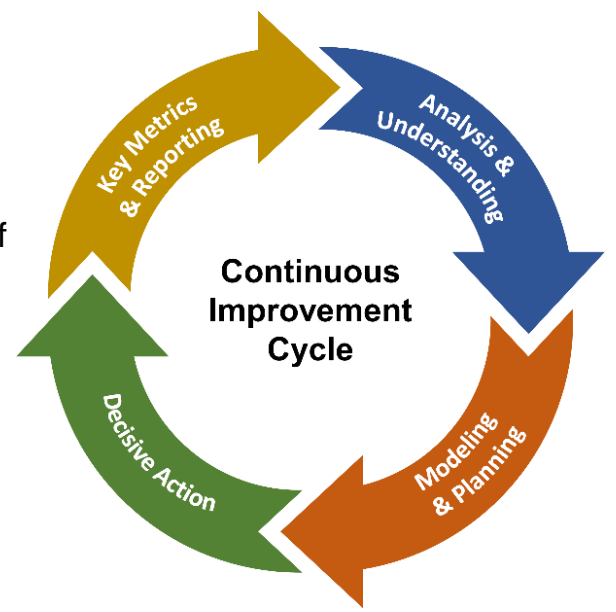


Figure A2.9. Professional Learning - Oxnard School District Master Plan for Services to English Learners (2019, p. 102)

\section{DISTRICT VISION: Empowering All Children to Achieve Excellence}

MISSION: Ensure a culturally diverse education for each student in a safe, healthy and supportive environment that prepares students for college and career opportunities.

PROFESSIONAL LEARNING GOAL: To promote educator quality and effectiveness for serving culturally and linguistically diverse students through the development of a professional learning community guided by Professional Learning Standards and effective practices for adult learning.

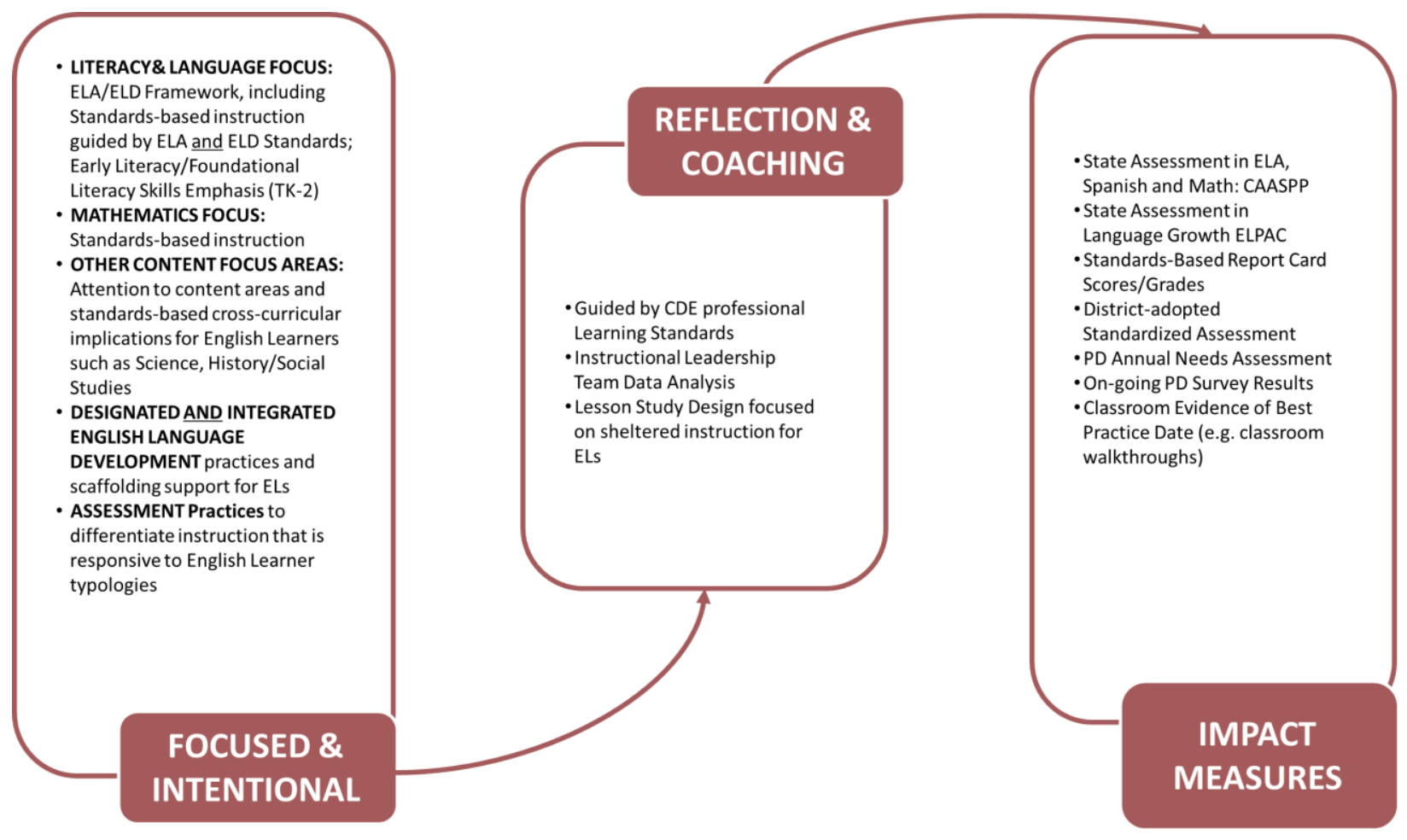


Figure A2. 10. Professional Learning: Core Values and Framework - Mountain View School District Master Plan for English Learners (2020, pages 85-86)
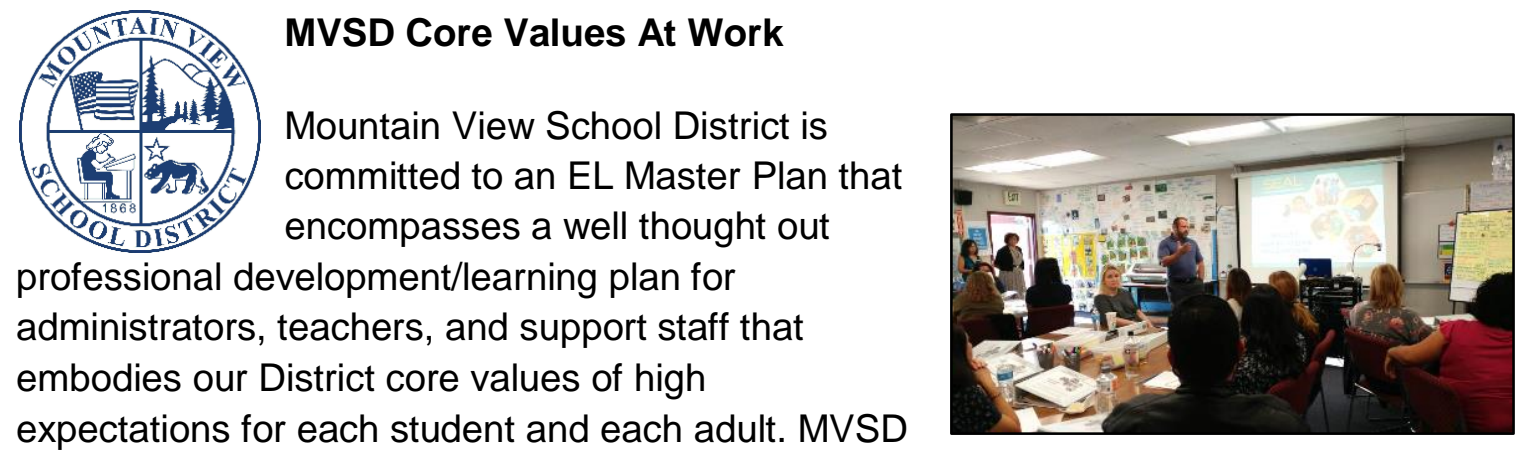

has aligned evidence-based English learner educational approaches and programs that have been designed to ensure continuity across grade levels and school sites. In order for the entire educational community to reap the benefits and accurately reflect the positive effects of proper implementation, these professional development/learning models are sustained and supported over considerable time and are of sufficient intensity. We believe in supporting the needs of the whole child by providing a joyful, culturally-responsive, rigorous learning environment based on standards-driven curricula, assessment measures, and evidence-based instructional strategies for English learners. Professional development/learning opportunities serve to further deepen teacher subject-matter knowledge, assessment measures, EL pedagogy, and to refine skills needed to guide students in becoming confident, multi-lingual, contributing members of the global community. We place high importance on the development of family and school partnerships in supporting student achievement. Therefore, District and site personnel take an active leadership role in involving parents/guardians in the educational process by providing parent workshops. Mountain View School District makes decisions for professional learning and leadership development based on input gathered from all stakeholders in combination with district achievement data and current research on best practices. 


\section{EL Roadmap Principles Addressed}

1. Assets-Oriented and Needs-Responsive Schools

2. Intellectual Quality of Instruction and Meaningful Access

3. System Conditions that Support Effectiveness

4. Alignment and Articulation Within and Across Systems

\section{Framework for District Professional Development and Learning}

MVSD responds to federal and state legal requirements for a professional learning and support system for teachers of English learners that represents the shift from professional development to professional learning that is:

- Targeted

- Individualized

- Based on principles of adult learning theory

- Sustained, supported with coaching and follow up

- Monitored and assessed to evaluate impact on student learning (Greatness by Design: California Professional Learning Standards, CDE, 2012)

\section{District and Site Professional Learning for all Staff Who Work with English Learners}

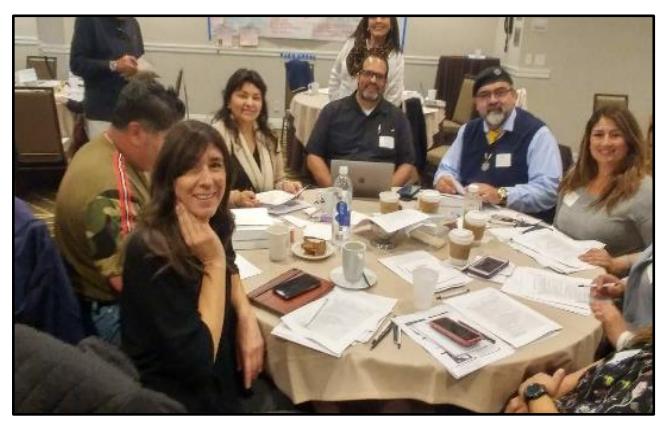

All administrators, certificated, and classified employees are provided with professional development/learning opportunities on research-based best practices for English learners. Professional development is aligned to state adopted standards, the California ELA/ELD Framework, the California Preschool Learning Foundations, and the 2017 California English Learner Roadmap

Policy. The implementation of the MVSD Instructional Framework is reflected across all school sites to provide students with a closely aligned and coherent learning experience both across sites and throughout grade levels.

MVSD follows an evidence-based best practices approach for high quality, effective, and job-embedded learning. Job embedded professional development is "teacher learning that is grounded in day-to-day teaching practice and is designed to enhance teachers' content-specific instructional practices with the intent of improving all students' learning" (Croft, Coggshall, Dolan, Powers, \& Killion, 2010, p. 2). Research has 


\section{APPENDIX 3: FAMILY-COMMUNITY ENGAGEMENT}

These resources support the development of an EL Master Plan focused on the third of four goals outlined in our Playbook which are: (I) Equitable, Coherent, and Sustainable Systems (2) Equity-driven Processes, Research-based Programs, and Practices (3) Family-Community Engagement; and (4) Accountability.

Goal 3: Family-Community Engagement can be written as a series of chapters, or any combination of chapters and include the following key component:

- Family-School Partnerships

\section{RESOURCES}

\section{Table A3. Family-School Partnerships}

\section{Resource}

Clark-Louque, A. R., Lindsey, R.

B., Quezada, R. L., \& Jew, C. L. (20 I 9). Equity partnerships: A culturally proficient guide to family, school, and community engagement. Corwin: Thousand Oaks, CA

\section{Summary}

This brief yet comprehensive guide for teachers and school leaders. Taking an asset-based approach the authors recognize that guided by cultural beliefs and principles, families select experiences, convey attitudes, and impart knowledge to their children in preparation for adulthood. The authors cover topics ranging from the why of engagement based on the $7 \mathrm{Cs}$ of engagement, to planning for inclusive partnering and capacity building. Clark-Louque et al. stress the importance of reaching out to, learning about, and developing strong partnerships with families.

Improving Education for begins with a discussion on evidence showing how assetMultilingual and English Learner Students: Research to Practice, Chapter 2- Asset-Based Pedagogy: Student, Family, and Community Engagement for the Academic and Social-Emotional Learning of Multilingual Students https://www.cde.ca.gov/sp/el/er/docum ents/mleleducationch2.pdf

Chapter 2 of the 2020 CDE publication cited earlier based pedagogy promotes the social-emotional and academic development of ML students. It then discusses the tenets of asset-based pedagogy, why it is important, and how teachers can develop this essential knowledge to engage in asset-based practices. The chapter also examines the associated problems of practice and specific pedagogical needs that educators of ML students often encounter. It then turns to a description of multiple examples, tools, and resources that have been successful for engaging multilingual students, families, and communities.

National Center for Family \& Community Connections with Schools https://www.sedl.org/connections/
The Center links people with research-based information and resources that they can use to effectively connect schools, families, and communities. It emphasizes 


\begin{tabular}{|c|c|}
\hline Resource & Summary \\
\hline & $\begin{array}{l}\text { connections that directly impact student achievement in } \\
\text { reading and mathematics, as well as connections that } \\
\text { contribute to the students' overall success in school and in } \\
\text { life. The website offers several toolkits and guides for } \\
\text { family and community involvement. }\end{array}$ \\
\hline $\begin{array}{l}\text { National Center for Family } \\
\text { Engagement } \\
\text { https://childcareta.acf.hhs.gov/centers/ } \\
\text { national-center-parent-family-and- } \\
\text { community-engagement }\end{array}$ & $\begin{array}{l}\text { The Center offers a variety of tools and resources to } \\
\text { support families and family engagement regarding Early } \\
\text { Childhood issues. }\end{array}$ \\
\hline $\begin{array}{l}\text { National Standards for School- } \\
\text { Family Partnership } \\
\text { https://www.pta.org/home/run-your- } \\
\text { pta/National-Standards-for-Family- } \\
\text { School-Partnerships }\end{array}$ & $\begin{array}{l}\text { The National Parent Teacher Association (PTA) website } \\
\text { offers tools, resources and information to support parents } \\
\text { and teachers. }\end{array}$ \\
\hline $\begin{array}{l}\text { National Clearinghouse for } \\
\text { English Language Acquisition: } \\
\text { Family Toolkit } \\
\text { https://www.ncela.ed.gov/family-toolkit } \\
\end{array}$ & $\begin{array}{l}\text { Created to help families choose education services that } \\
\text { meet their child's needs. U.S. educators, elementary and } \\
\text { secondary school teachers, principals, and other school } \\
\text { staff can also share the toolkit as a resource for English } \\
\text { learners and their families. Each of the toolkit } 6 \text { chapters } \\
\text { consists of an overview, family and students' rights, } \\
\text { questions to ask schools, tips and resources. }\end{array}$ \\
\hline $\begin{array}{l}\text { OELA } \\
\text { United States Department of } \\
\text { Education: EL Toolkit, Chapter I0 } \\
\text { - } \\
\text { Tools and Resources for Ensuring } \\
\text { Meaningful Communication with } \\
\text { Limited English Proficient } \\
\text { Parents } \\
\text { https://www2.ed.gov/about/offices/list/ } \\
\text { oela/english-learner-toolkit/chap/0.pdf }\end{array}$ & $\begin{array}{l}\text { This chapter outlines SEAs and LEAs obligations in } \\
\text { communicating with parents as well as the necessary } \\
\text { processes. It also provides tools and resources. }\end{array}$ \\
\hline $\begin{array}{l}\text { The Dual Capacity-Building } \\
\text { Framework for Family-School } \\
\text { Partnerships }\end{array}$ & $\begin{array}{l}\text { The Dual Capacity-Building Framework for Family-School } \\
\text { Partnerships (Version 2) is designed by Mapp, K.L. \& }\end{array}$ \\
\hline
\end{tabular}




\begin{tabular}{|c|c|}
\hline Resource & Summary \\
\hline $\begin{array}{l}\text { https://www.dualcapacity.org/https:/ } \\
\text { /www2.ed.gov/documents/family- } \\
\text { community/partners-education.pdf }\end{array}$ & $\begin{array}{l}\text { Bergman, E (2019) to support the development of family } \\
\text { engagement strategies, policies and programs. }\end{array}$ \\
\hline $\begin{array}{l}\text { The Early Years: Assets-Based, } \\
\text { Language-Focused Family } \\
\text { Engagement for Dual Language } \\
\text { Learners } \\
\text { https://wida.wisc.edu/sites/default/fi } \\
\text { les/resource/FocusOn-EY-Family- } \\
\text { Engagement-DLLs.pdf }\end{array}$ & $\begin{array}{l}\text { This Focus Bulletin from the WIDA Consortium looks at } \\
\text { how teachers can maximize family engagement by } \\
\text { adopting an assets-based perspective and identifying } \\
\text { language goals when working with DLLs and their parents. } \\
\text { It also provides suggestions for supporting and how to } \\
\text { advocate for families' efforts to achieve language and } \\
\text { cultural goals they desire for their children. }\end{array}$ \\
\hline
\end{tabular}

\section{EXAMPLES}

These examples are drawn from six districts across the state and exemplify promising approaches to detailing equitable education local policies for Multilingual and English learner students. Together with the resources in Appendix 3, the examples are intended to support LEA team's development of an EL Master Plan focused on the third of four goals outlined in our Playbook which are: (I) Equitable, Coherent, and Sustainable Systems (2) Equity-driven Processes, Research-based Programs, and Practices (3) Family-Community Engagement; and (4) Accountability.

Goal 3: Family-Community Engagement includes one key component: Family-School Partnerships. To reference content criteria for each of this component, see Step 3: Chapter Analysis, Reflection, and Evaluation (CARE) Tool in this Playbook.

We acknowledge and appreciate the leadership, commitment, and vision for excellence and equity for Multilingual and English Learner students exhibited by the following districts highlighted in this publication:

- Burbank Unified School District Master Plan for English Learners (2021-24) https://www.burbankusd.org/Page/2186

- Los Angeles Unified School District 2018 Master Plan for English Learners and Standard English Learners (2018) https://achieve.lausd.net/cms/lib/CA0I000043/Centricity/domain/22/el\%20sel\%20master\%20plan/2018\%20 Master\%20Plan\%20for\%20EL\%20and\%20SEL.pdf

- Mountain View School District Master Plan for English Learners (2020) Permission granted to include examples; Link not yet available on district website.

- Novato Unified School District English Learner Master Plan - Engage Empower Inspire towards Biliteracy! (2019/20) https://nusd.org/wp-content/uploads/2020/08/NUSD-English-Learner-Master-Plan-2019-20-WebsiteGoogle-Docs.pdf 
- Oakland Unified School District's ELL Master Plan (2016)

https://www.ousd.org/Page/ 17073

- Oxnard School District Master Plan for Services to English Learners (2019)

https://www.oxnardsd.org/site/handlers/filedownload.ashx?moduleinstanceid=|262| \&dataid=10290\&FileN ame=ELPM\%20English\%202019\%20Final.pdf

Figure A3.I Family-School Partnerships: Family Engagement Framework District Principles - Los Angeles Unified School District 2018 Master Plan for English Learners and Standard English Learners (2018, page 6I)

\section{L.A. Unified 2018 Master Plan For English Learners and Standard English Learners}

Figure 21: Family Engagement Framework District Principles

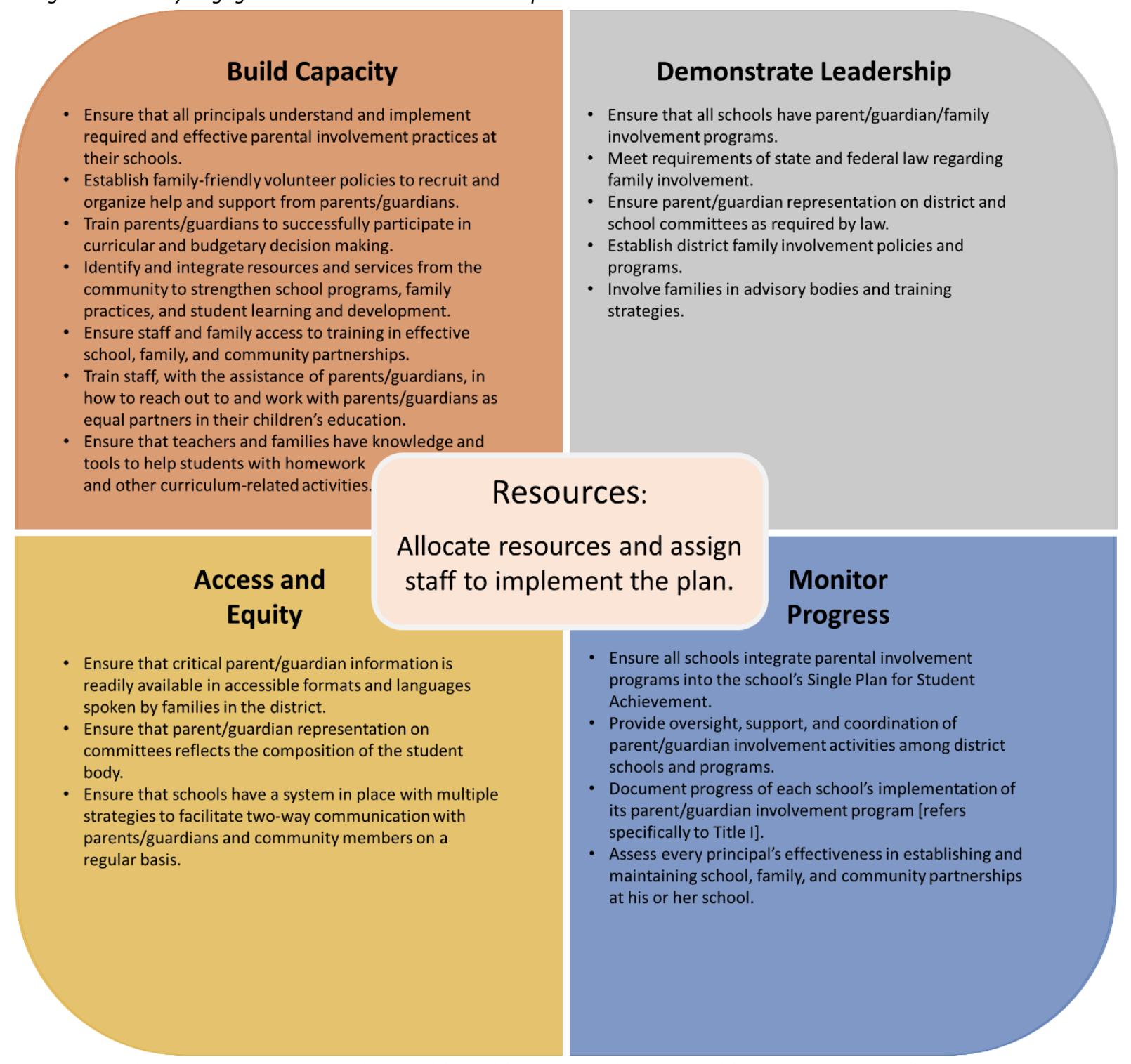

Source: Family Engagement Framework, A Tool for California School District, California Department of

Education, 2014, p 9 . 
Figure A3.2 Family-School Partnerships: Family Engagement Framework District Principles - Los Angeles Unified School District 2018 Master Plan for English Learners and Standard English Learners (2018, page 63)

\section{Family Engagement Activities \\ SCHOOL INITIATED \\ FAMILY \\ IN ITIATED}

\section{At the District}

- Solicit input from families on district family engagement policies.

- Provide training on curricular and budgetary decision-making for parent coordinators and families.

- Create and support parent centers at school sites.
- Participate on district-level advisory committees.

- Participate in planning and delivery of staff training on parent involvement.

- Participate in development and review of district- and school-level parent involvement plans and policies.
- Create a welcoming environment.

- Celebrate families and the assets they bring to schools.

- Work with families as partners to improve student achievement.

- Assist families to access community resources.

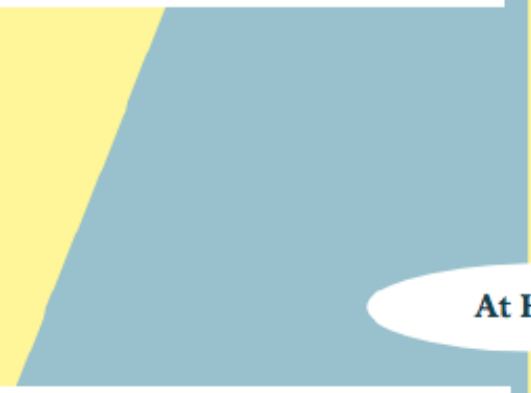

- Promote effective two-way communication with families.

- Assist families to create home conditions to support academic achievement.

- Provide information on expectations, standards, and how families can be involved, in an accessible language and format.

- Keep families informed on student progress and maintain regular communication.

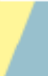

At School

- Attend parent-teacher conferences.

- Visit your child's classroom.

- Volunteer in the classroom (your child's or another classroom).

- Volunteer at lunch or after school to support students.

- Attend or support schoolwide events.

- Visit the parent resource center.

- Attend advisory committee meetings.

- Participate on school-level advisory committees.

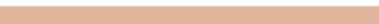

\section{At Home}

- Provide quiet space at home for homework.

- Limit TV watching and video games.

- Read out loud to your student.

- Talk about school and the importance of learning.

- Respond to school surveys.

- Communicate with teachers about questions or concerns.

- Talk about college and careers.

- Help organize homework.

- Link learning to current events. 


\section{Figure A3.3. Family-School Partnerships: What do schools need to do? Oakland Unified School District's ELL Master Plan (2016, page 55)}

\section{FAMILY AND COMMUNITY ENGAGEMENT}

\section{INTRODUCTION}

Our schools and classrooms are most effective when family and community stakeholders actively influence and contribute to the District mission of college, career and community readiness. In the case of English Language Learner (ELL) families and community leaders, this involvement is of particular importance because it helps immigrant and ELL families experience ownership in an educational system that might be unfamiliar.

In alignment with the OUSD Standards for Meaningful Family Engagement and the OUSD Student Engagement Standards, structures and practices to support ELL family and community participation in OUSD must:

- Be clearly defined and well-advertised in a parent friendly format, at both the site and district level.

- Be welcoming and culturally and linguistically responsive .

- Provide a space for parents and families to both learn about and contribute to

- the specific needs of ELLs including all ELL subgroups.

- the educational needs of all OUSD students and subgroups .

- Fully engage parents representing all ELL subgroups in site-level and district-level governance structures, particularly within the School Site Council (SSC), District ELL Parent Subcommittee (DELLS) and Site ELL Subcommittee (SELLS). (See descriptions pages 57 - 58.)

- Ensure clear communication and connection between the parent governance struc-

- Be supported by dedicated family liaisons and resources at the site, Network and District level. tures at the site level and the parent governance structures at the district level.

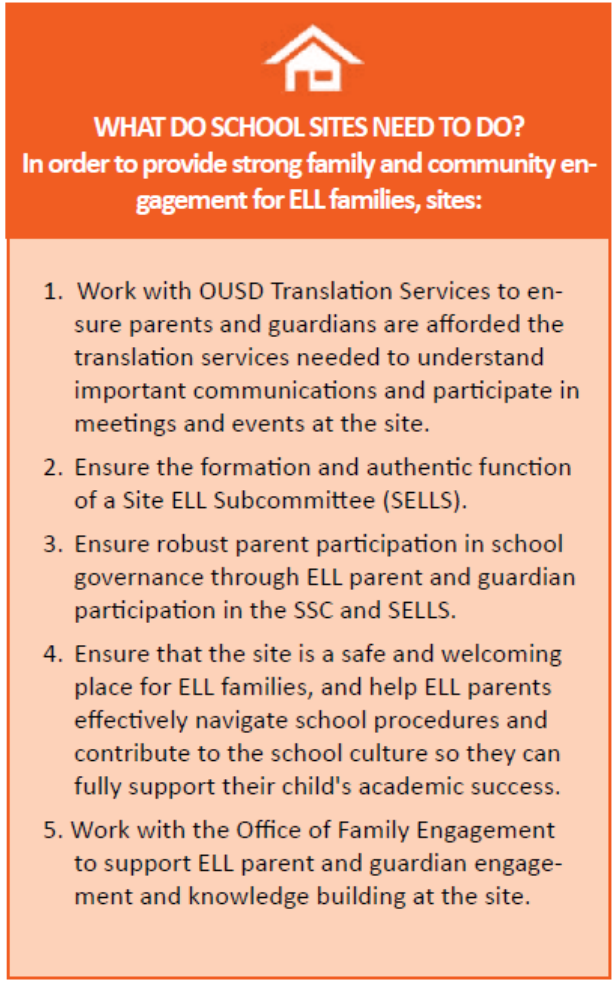

OUSD ELL Master Plan: Chapter 3 


\section{Figure 3.4 Family-School Partnerships: Burbank Unified School District Master Plan for English Learners (202I-24, page 63)}

The district provides staff development to all school staff on how to work with parents, including communication skills and sensitivity to their backgrounds, needs and concerns. The district and schools will continue to provide parent outreach and education, including meetings, workshops, and programs for parents and families. The District's LEA plan, LCAP, and school plans will outline measurable goals, objectives and activities that promote parent involvement.

\section{Immigrant Involvement:}

Understanding an immigrant family's background and motivations for coming to the U.S. can help schools and educators be better positioned to help them transition into a new school and community culture. Han and Love (2015) developed a model (below) of four stages of parent/guardian involvement that they believe immigrant families move through: cultural survivor, cultural learner, cultural connection, and cultural leader.

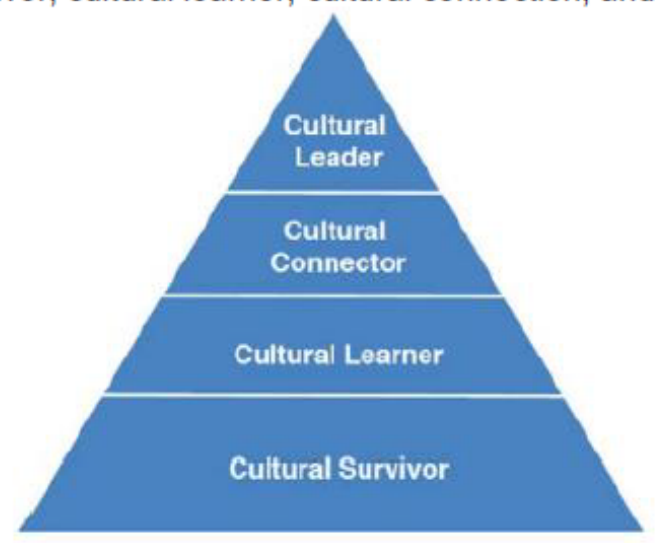

- Cultural survivors may be recently arrived immigrants. Many will be concerned about securing food and shelter and may not have much time to learn about and navigate the U.S. school system.

- Cultural learners may feel somewhat at ease with the school and want to learn more about what is taught, the school culture, and other aspects of the school. Han and Love contend that cultural learners are more comfortable than cultural survivors with the new school culture and the U.S. education system. "With the help of qualified and trained interpreters and translated documents, parents communicate with schools and learn to navigate the U.S. school system. They feel more comfortable attending workshops in their native language and are likely to participate in parent-teacher conferences with language support" (Han \& Love, 2015).

- Cultural connectors become familiar with educational terminology, policies, and procedures. They may wish to work with cultural survivors and cultural learners, to encourage them, and to help them understand and engage in school programs and activities that support students and parents.

- Cultural leaders often become the "voice" of their ethnic and language community and advocate for parents in the other stages. They may become leaders and participate in trainings.

$63 \mid \mathrm{P}$ a g e 
Figure 3.5. Family-School Partnerships: Family Engagement Framework - Mountain View School District Master Plan for English Learners (2020, page 52)

Figure 3.1 Family Engagement Framework

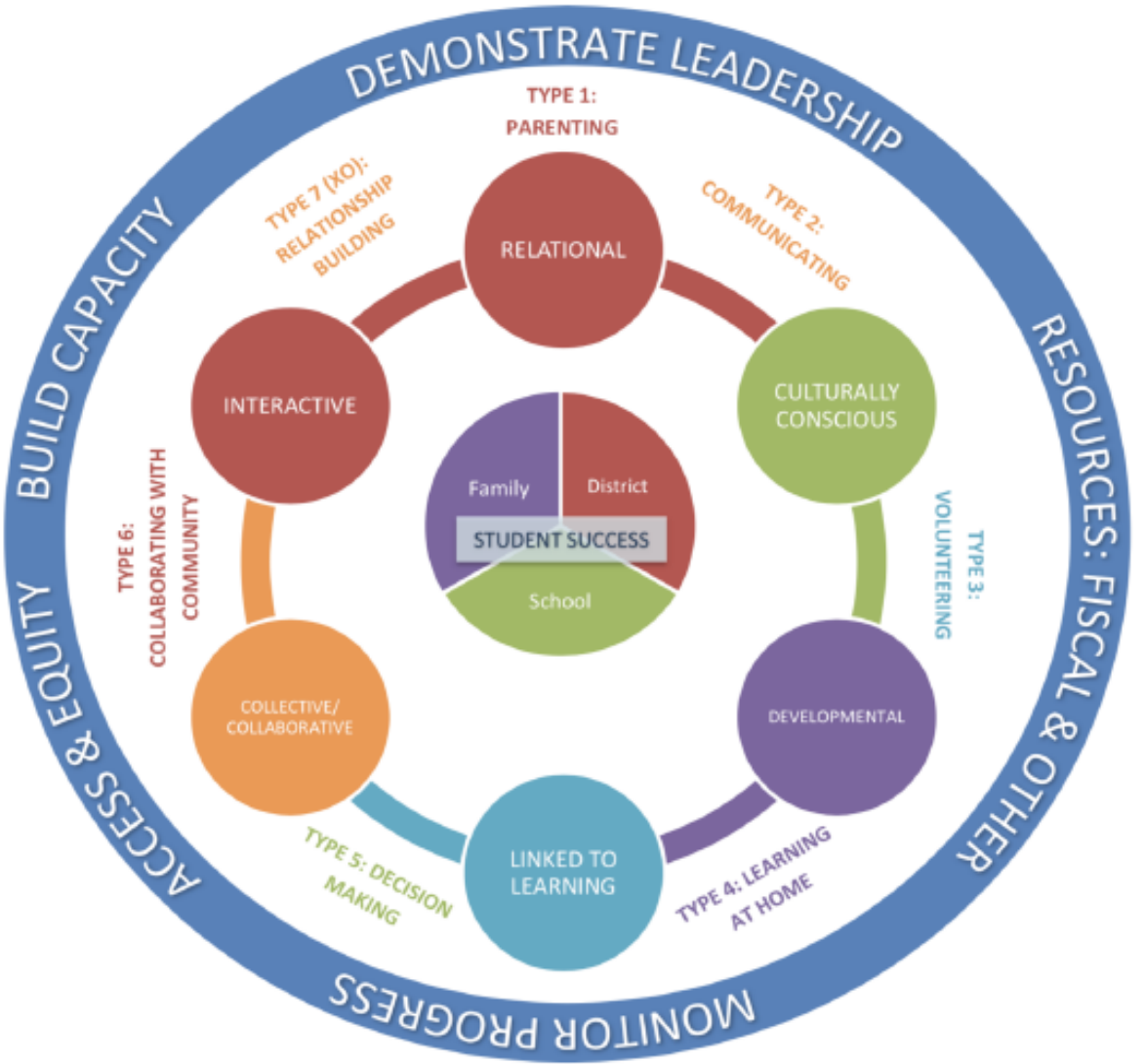

"Family Engagement Framework: A Tool for California Schools (CDE 2014), "Parents in Action" by Dr. Karen Mapp, and "School, Family, and Community Partnerships" by Dr. Joyce Epstein are the three major publications in the field that comprise our Family Engagement action plan. Figure 3.1 above illustrates how the work from the three publications come together to guide the work we do with families and the community at large. At the heart of it all, we know that building family, school, and District relationships facilitate clear communication and collaboration, which are the foundation for student success. 


\section{APPENDIX 4: ACCOUNTABILITY}

These resources support the development of an EL Master Plan focused on the fourth of four goals outlined in our Playbook which are: (I) Equitable, Coherent, and Sustainable Systems (2) Equity-driven Processes, Research-based Programs, and Practices (3) Family-Community Engagement; and (4) Accountability.

Goal 4: Accountability of the EL Master Plan can be written as a series of chapters, or any combination of chapters and includes 2 key components:

- Assessment and Student Monitoring

- Program Monitoring and Evaluation

\section{RESOURCES}

\begin{tabular}{|l|}
\hline Table A4. Assessment and Accountabili \\
\hline Resource \\
\hline ELD/ELA Framework for California \\
Schools, CA Department of \\
Education, 2015 \\
Chapter 8: Assessment \\
https://www.cde.ca.gov/ci/rl/cf/documents/e \\
laeldfwchapter8.pdf
\end{tabular}

Focusing Formative Assessment on the Needs of English Language Learners, West Ed, 2014 by Laura Alvarez, Sri Ananda, Aída Walqui, Edynn Sato, Stanley N. Rabinowitz https://www.wested.org/wpcontent/uploads/2016/II//391626953Form ativeAssessment_report5-3.pdf

\section{Summary}

Chapter 8 of the ELA/ELD Framework provides guidance on assessment by explaining formative and middle and long-cycle summative assessments. The chapter addresses considerations for assessing ELs mid-cycle and for ensuring access on Long-cycle assessments. It also discusses the assessment of ELD progress through Writing and Oral Language assessments for ELs.

The authors examine how formative assessment can enhance the teaching and learning of ELL students in particular. They highlight the opportunities and challenges inherent in integrating formative assessment into instruction for ELL students around Common Core and other "next generation" standards. They argue that in order to use formative assessment effectively with this student population, teachers must attend simultaneously to the students' needs both in learning content and skills and in developing the English required to express their learning.

Guidance On Diagnostic and Formative Assessments, CDE, 2020 https://www.cde.ca.gov/ls/he/hn/documents/ guidanceonassessments.pdf
This guidance describes how local educational agencies (LEAs) can use California's approved assessments to evaluate where students are academically at the start of and throughout the school year. 


\begin{tabular}{|c|c|}
\hline & $\begin{array}{l}\text { The assessment tools provided include the } \\
\text { Smarter Balanced assessment system, } \\
\text { developed by the Smarter Balanced } \\
\text { Assessment Consortium, which is freely } \\
\text { available to all public school districts, schools, } \\
\text { and teachers in California. The guidance also } \\
\text { includes a listing of additional tools approved } \\
\text { for diagnostic assessment in grade two-all of } \\
\text { which measure the state standards and have } \\
\text { the capacity to assess student progress across } \\
\text { a longer continuum of performance, typically } \\
\text { covering the ELA and mathematics domains in } \\
\mathrm{K}-8 \text { or K-12. }\end{array}$ \\
\hline $\begin{array}{l}\text { OELA } \\
\text { United States Department of Education: EL } \\
\text { Toolkit, Chapter } 9 \text { - Tools and Resources } \\
\text { for Evaluating the Effectiveness of an EL } \\
\text { Program } \\
\text { https://www2.ed.gov/about/offices/list/oela/ } \\
\text { english-learner-toolkit/chap9.pdf }\end{array}$ & $\begin{array}{l}\text { This is the ninth chapter of the English Learner } \\
\text { Tool Kit, which is intended to help state and } \\
\text { local education agencies (SEAs and LEAs) meet } \\
\text { their obligations to English Learners (ELs). This } \\
\text { tool kit should be read in conjunction with the } \\
\text { U.S. Department of Education Office for Civil } \\
\text { Rights' and the U.S. Department of Justice's } \\
\text { Dear Colleague Letter on "English Learner } \\
\text { Students and Limited English Proficient } \\
\text { Parents," published in January 20I5, which } \\
\text { outlines SEAs' and LEAs' legal obligations to } \\
\text { ELs under civil rights laws and other federal } \\
\text { requirements. The Dear Colleague Letter can } \\
\text { be found at } \\
\text { http://www2.ed.gov/about/offices/list/ocr/ellres } \\
\text { ources.html. }\end{array}$ \\
\hline
\end{tabular}

\section{EXAMPLES}

These examples are drawn from six districts across the state and exemplify promising approaches to detailing equitable education local policies for Multilingual and English learner students. Together with the resources in Appendix 4, the examples are intended to support LEA team's development of an EL Master Plan focused on the fourth of four goals outlined in our Playbook which are: (I) Equitable, Coherent, and Sustainable Systems (2) Equity-driven Processes, Research-based Programs, and Practices (3) Family-Community Engagement; and (4) Accountability. 
Goal 4: Accountability includes 2 key components: (a) Assessment and Student Monitoring and (b) Program Monitoring and Evaluation. To reference content criteria for each of these components, see Step 3: Chapter Analysis, Reflection, and Evaluation (CARE) Tool in this Playbook.

We acknowledge and appreciate the leadership, commitment, and vision for excellence and equity for Multilingual and English Learner students exhibited by the following districts highlighted in this publication:

- Burbank Unified School District Master Plan for English Learners (2021-24) https://www.burbankusd.org/Page/2186

- Los Angeles Unified School District 2018 Master Plan for English Learners and Standard English Learners (2018) https://achieve.lausd.net/cms/lib/CA01000043/Centricity/domain/22/el\%20sel\%20master\%20plan/20I8\%20 Master\%20Plan\%20for\%20EL\%20and\%20SEL.pdf

- Mountain View School District Master Plan for English Learners (2020) Permission granted to include examples; Link not yet available on district website.

- Novato Unified School District English Learner Master Plan - Engage Empower Inspire towards Biliteracy! (2019/20) https://nusd.org/wp-content/uploads/2020/08/NUSD-English-Learner-Master-Plan-2019-20-WebsiteGoogle-Docs.pdf

- Oakland Unified School District's ELL Master Plan (2016) https://www.ousd.org/Page//7073

- Oxnard School District Master Plan for Services to English Learners (2019) https://www.oxnardsd.org/site/handlers/filedownload.ashx?moduleinstanceid=12621 \&dataid=10290\&FileN ame=ELPM\%20English\%202019\%20Final.pdf 
Figure A4. I. Assessment and Student Monitoring: Systematic Approach for Monitoring of ELs. Mountain View School District Master Plan for English Learners (2020, page 98)

Figure 6.1 Systematic Approach for Monitoring of ELs

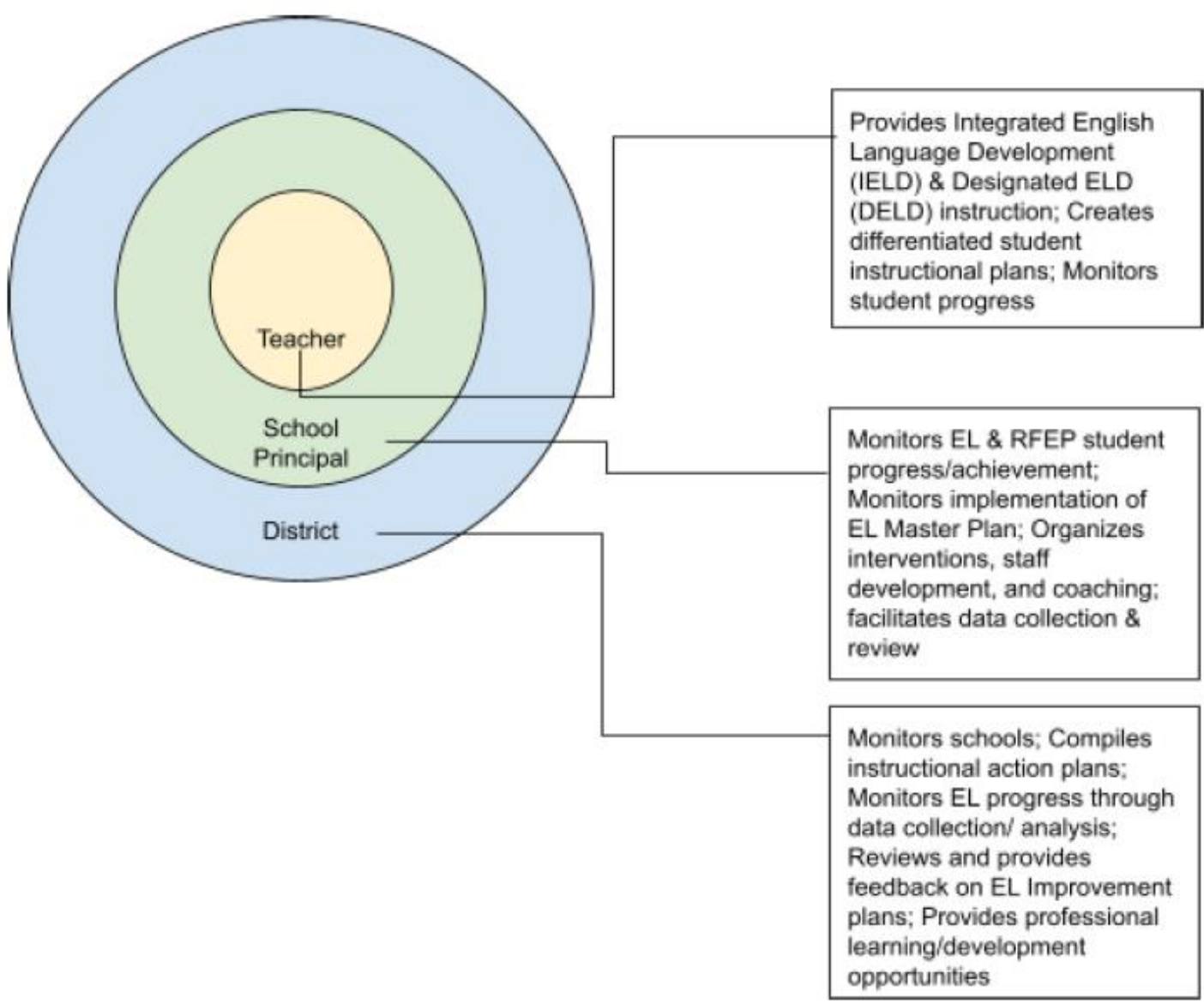




\section{Figure A4.2 Assessment and Student Monitoring: Minimum Progress Expectations - Oakland Unified School District's ELL Master Plan (2016, pages 44-45)}

\section{2 \\ INSTRUCTIONAL PROGRAMS FOR ELLS}

\section{MINIMUM PROGRESS EXPECTATIONS}

Clear minimum progress expectations allow individuals, sites and other stakeholders in the system to hold themselves accountable for the quality of instruction for ELLs in OUSD. In this section, we provide graphics detailing the minimum progress expectation for each instructional program.

Failure to meet minimum progress indicates the need for interventions, discussed in this chapter in Section 6: INTERVENTIONS WITHIN MTSS FOR ELLS NOT MEETING MINIMUM PROGRESS EXPECTATIONS. To understand the minimum expectations tables (below), follow the different students across multiple years, bearing these points in mind:

1. No matter the English proficiency level of a student when they enroll in a particular instructional program, reclassification is expected to occur by the time they reach the far right column of the table.

2. All the English proficiency and academic achievement indicators in the columns are "end-of-year" expectations.
3. The assumption is that a student begins the year about "one year's growth" behind the end-of-year target. For example:

- A student expected to finish the year at "High Preemerging/Low Emerging" (the far left column for English proficiency in the table below) would have begun the school year knowing almost no English.

- A student expected to finish the year at "High Expanding" would have begun the school year at the "High Emerging" level (which is the column to the left of "High Expanding").

4. A student's first year in an instructional language program in OUSD can happen at any grade level or at any English proficiency level, depending on the student's history.

See Minimum Progress Expectations by ELL Group and Program for further graphics pertaining to specific ELL groups (e.g. newcomers, or SIFE students) and specific instructional programs.

\section{ELAP INSTRUCTIONAL PROGRAM MINIMUM PROGRESS EXPECTATIONS FOR ELLS}

\begin{tabular}{|c|c|c|c|c|c|}
\hline & ELPAC 1 & ELPAC 2 & ELPAC 3 & Low ELPAC 4 & $\begin{array}{l}\text { Mid to High } \\
\text { ELPAC } 4 \text { and } \\
\text { reclassification }\end{array}$ \\
\hline End of Year 1 & Student A & Student B & Student C & Student D & Student E \\
\hline End of Year 2 & & Student A & Student B & Student C & Student D \\
\hline End of Year 3 or 4 & & & Student A & Student B & Student C \\
\hline End of Year 4 or 5 & & & & Student A & Student B \\
\hline End of Year 5 or 6 & & & & & Student A \\
\hline
\end{tabular}

\begin{tabular}{|l|l|l|l|l|l|}
\hline \multicolumn{7}{|c|}{ Other End-of-Year Minimum Progress Academic Achievement Indicators } \\
\hline ENGLISH READING & $\begin{array}{l}\text { 1 to } 3 \text { grade levels } \\
\text { below RI or Read- } \\
\text { ing Record }\end{array}$ & $\begin{array}{l}1 \text { to } 2.5 \text { grade } \\
\text { levels below RI or } \\
\text { Reading Record }\end{array}$ & $\begin{array}{l}1 \text { to } 2 \text { grade levels } \\
\text { below or less RI or } \\
\text { Reading Record }\end{array}$ & $\begin{array}{l}1 \text { to } 1.5 \text { grade } \\
\text { levels below or } \\
\text { less (meet OUSD } \\
\text { RI Reclassification } \\
\text { criteria) }\end{array}$ & $\begin{array}{l}\text { l to less than } 1 \\
\text { grade levels below } \\
\text { (meet or exceed } \\
\text { OUSD RI Reclassifi- } \\
\text { cation criteria) }\end{array}$ \\
\hline $\begin{array}{l}\text { SBAC/IAB ELA \& } \\
\text { MATH }\end{array}$ & Standard Not Met & $\begin{array}{l}\text { Standard Not Met/ } \\
\text { Nearly Met }\end{array}$ & $\begin{array}{l}\text { Standard Nearly } \\
\text { Met }\end{array}$ & $\begin{array}{l}\text { Standard Nearly } \\
\text { Met/Met }\end{array}$ & $\begin{array}{l}\text { Standard Nearly } \\
\text { Met/Met }\end{array}$ \\
\hline
\end{tabular}


Figure A4.3. Assessment and Student Monitoring: English and Spanish Language Development Proficiency Assessments Oxnard School District Master Plan for Services to English Learners (2019, page 53)

\section{Table 4.1 English Language Development Proficiency Assessments}

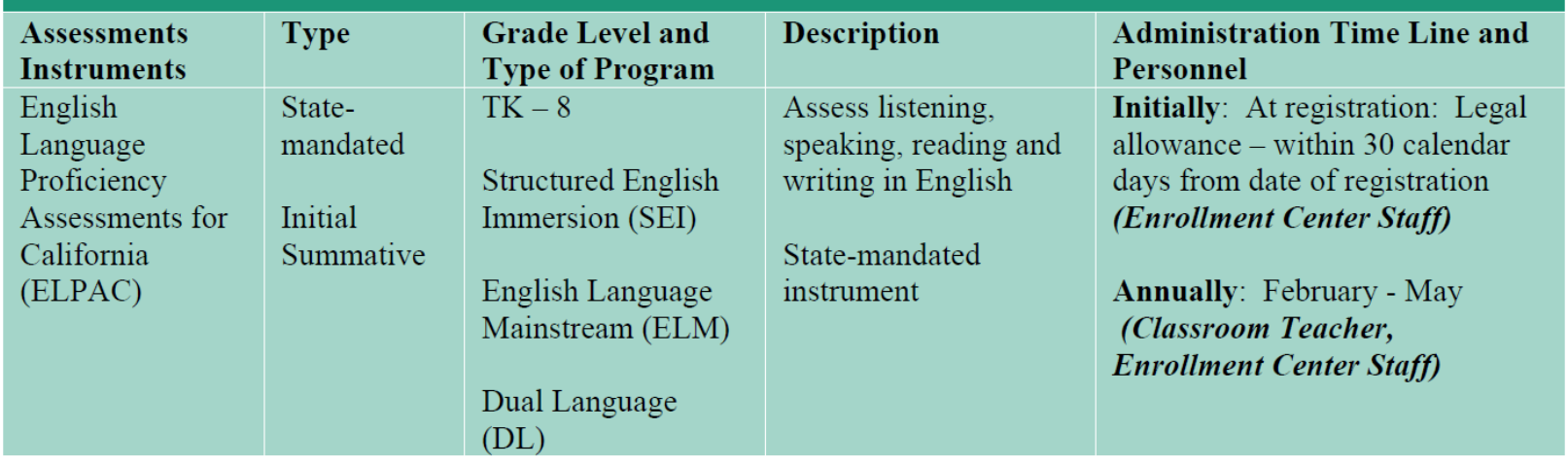

\section{Table 4.2 English and Spanish Language Development Proficiency Assessments}

\begin{tabular}{|c|c|c|c|c|}
\hline $\begin{array}{l}\text { Assessments } \\
\text { Instrument(s) }\end{array}$ & Type & $\begin{array}{l}\text { Grade Level and } \\
\text { Type of Program }\end{array}$ & Description & $\begin{array}{l}\text { Administration Time } \\
\text { Line and Personnel }\end{array}$ \\
\hline $\begin{array}{l}\text { English Standardized } \\
\text { Language Proficiency } \\
\text { Assessment }\end{array}$ & $\begin{array}{l}\text { District-adopted } \\
\text { Summative }\end{array}$ & $\begin{array}{l}\text { TK }-8 \\
\text { SEI } \\
\text { ELM } \\
\text { TBE } \\
\text { DL }\end{array}$ & $\begin{array}{l}\text { Standardized Assessment of } \\
\text { listening, speaking, reading, } \\
\text { writing }\end{array}$ & $\begin{array}{l}\text { Initial: For all new enrollees: } \\
\text { Used as a diagnostic tool upon } \\
\text { enrollment, if prior to July } \\
\text { (Enrollment Center Staff) } \\
\text { Annually: } \\
\text { Administered at a different time } \\
\text { than the ELPAC assessment. }\end{array}$ \\
\hline Curriculum-embedded & $\begin{array}{l}\text { District-adopted } \\
\text { Summative and } \\
\text { Formative }\end{array}$ & $\begin{array}{l}\text { TK-8 } \\
\text { SEI } \\
\text { ELM } \\
\text { TBE } \\
\text { DL }\end{array}$ & $\begin{array}{l}\text { Assess progress in listening, } \\
\text { speaking, reading, and } \\
\text { writing proficiency in } \\
\text { English } \\
\text { Based on the use of district } \\
\text { adopted ELD materials }\end{array}$ & $\begin{array}{l}\text { On-going } \\
\text { (Classroom Teacher) }\end{array}$ \\
\hline $\begin{array}{l}\text { Local District Spanish } \\
\text { Language Proficiency } \\
\text { Assessment }\end{array}$ & $\begin{array}{l}\text { District-adopted } \\
\text { Summative }\end{array}$ & $\begin{array}{l}\text { TK -8 } \\
\text { Dual Language }\end{array}$ & $\begin{array}{l}\text { Local District assessments of } \\
\text { listening, speaking, reading, } \\
\text { writing } \\
\text { Provides diagnostic } \\
\text { assessment of progress in DL } \\
\text { programs and Spanish } \\
\text { language proficiency }\end{array}$ & $\begin{array}{l}\text { Initial: For all new enrollees - } \\
\text { Used as a diagnostic tool upon } \\
\text { enrollment } \\
\text { (Enrollment Center Staff) } \\
\text { Annually: } \\
\text { Two times per year } \\
\text { Mid-year and End of Year } \\
\text { (Classroom Teacher) }\end{array}$ \\
\hline Curriculum-embedded & $\begin{array}{l}\text { District-adopted } \\
\text { Summative and } \\
\text { Formative }\end{array}$ & $\begin{array}{l}\text { TK-8 } \\
\text { DL }\end{array}$ & $\begin{array}{l}\text { Assess progress in listening, } \\
\text { speaking, reading, and } \\
\text { writing proficiency in } \\
\text { Spanish } \\
\text { Based on the use of Spanish } \\
\text { core materials and CCSS }\end{array}$ & $\begin{array}{l}\text { On-going } \\
\text { (Classroom Teacher) }\end{array}$ \\
\hline
\end{tabular}


Figure A4.4. Assessment and Student Monitoring: English and Spanish Academic Achievement Assessments Oxnard School District Master Plan for Services to English Learners (2019, page 54)

\begin{tabular}{|c|c|c|c|c|}
\hline $\begin{array}{l}\text { Assessments } \\
\text { Instruments }\end{array}$ & Type & $\begin{array}{l}\text { Grade Level and } \\
\text { Type of Program }\end{array}$ & Description & $\begin{array}{c}\text { Administration } \\
\text { Time Line and } \\
\text { Personnel }\end{array}$ \\
\hline $\begin{array}{l}\text { CAASPP (SBAC) } \\
\text { English }\end{array}$ & $\begin{array}{l}\text { State-mandated } \\
\text { Summative }\end{array}$ & $\begin{array}{l}\text { 3-8 } \\
\text { Structured English } \\
\text { Immersion (SEI) } \\
\text { English Language } \\
\text { Mainstream (ELM) } \\
\text { Transitional Bilingual } \\
\text { Education (TBE) } \\
\text { Dual Language (DL) }\end{array}$ & $\begin{array}{l}\text { On-line assessment system aligned to the } \\
\text { Common Core State Standards (CCSS) } \\
\text { English Language Arts } \\
\text { Mathematics }\end{array}$ & $\begin{array}{l}\text { Annually: Spring } \\
\text { (Classroom Teacher) }\end{array}$ \\
\hline $\begin{array}{l}\text { English Standardized } \\
\text { Assessments }\end{array}$ & District-adopted & $\begin{array}{l}\text { K-8 } \\
\text { SEI } \\
\text { ELM } \\
\text { TBE } \\
\text { DL }\end{array}$ & $\begin{array}{l}\text { K-8 assessment allowing educators to } \\
\text { screen and group students for targeted } \\
\text { instruction, measure student growth, } \\
\text { predict performance on CAASPP, and } \\
\text { monitor achievement on CCSS }\end{array}$ & $\begin{array}{l}\text { On-going: } \\
\text { Typically } 1 \mathrm{x} \text { per } \\
\text { trimester } \\
\text { (Classroom Teacher) }\end{array}$ \\
\hline $\begin{array}{l}\text { English Curriculum- } \\
\text { embedded }\end{array}$ & $\begin{array}{l}\text { District-adopted } \\
\text { Summative and } \\
\text { Formative }\end{array}$ & $\begin{array}{l}\text { TK-8 } \\
\text { SEI } \\
\text { ELM } \\
\text { TBE } \\
\text { DL }\end{array}$ & $\begin{array}{l}\text { Assess academic progress in designated } \\
\text { content areas taught in English, according } \\
\text { to program design (see Chapter 3, } \\
\text { Instructional Programs) } \\
\text { Based on the use of core content state- } \\
\text { adopted materials }\end{array}$ & $\begin{array}{l}\text { On-going } \\
\text { (Classroom Teacher) }\end{array}$ \\
\hline $\begin{array}{l}\text { Spanish Curriculum- } \\
\text { embedded }\end{array}$ & $\begin{array}{l}\text { District-adopted } \\
\text { Summative and } \\
\text { Formative }\end{array}$ & $\begin{array}{l}\text { TK-8 } \\
\text { TBE } \\
\text { DL }\end{array}$ & $\begin{array}{l}\text { Assess academic progress in designated } \\
\text { content areas taught in Spanish, according } \\
\text { to program design (see Chapter } 3, \\
\text { Instructional Programs) } \\
\text { Based on the use of core content } \\
\text { standards based materials }\end{array}$ & $\begin{array}{l}\text { On-going } \\
\text { (Classroom Teacher) }\end{array}$ \\
\hline
\end{tabular}


Figure A4.5. Assessment and Student Monitoring: Multi-tiered System of Supports and English Learners - Oxnard School District Master Plan for Services to English Learners (2019, page 57)

\section{Multi-tiered System of Supports and English Learners}

Oxnard School District uses Multi-Tiered System of Supports (MTSS) for data-based decision making, problem-solving, and professional development to focus on quality instruction, identify student instructional needs, continually monitor student progress, and provide evidence-based interventions. The LAT applies the MTSS model (see Figure 1) to enact the multi-level instructional system in order to maximize student achievement and to reduce behavioral problems (CDE, ELA/ELD Framework, Chapter 9, p. 913).

MTSS is defined as a whole-school data drive, prevention-based framework for improving outcomes for EVERY student through a layered continuum of evidence-based practices and systems (see Figure 1)

\section{Multi-Tiered Systems of Support and English Learners}

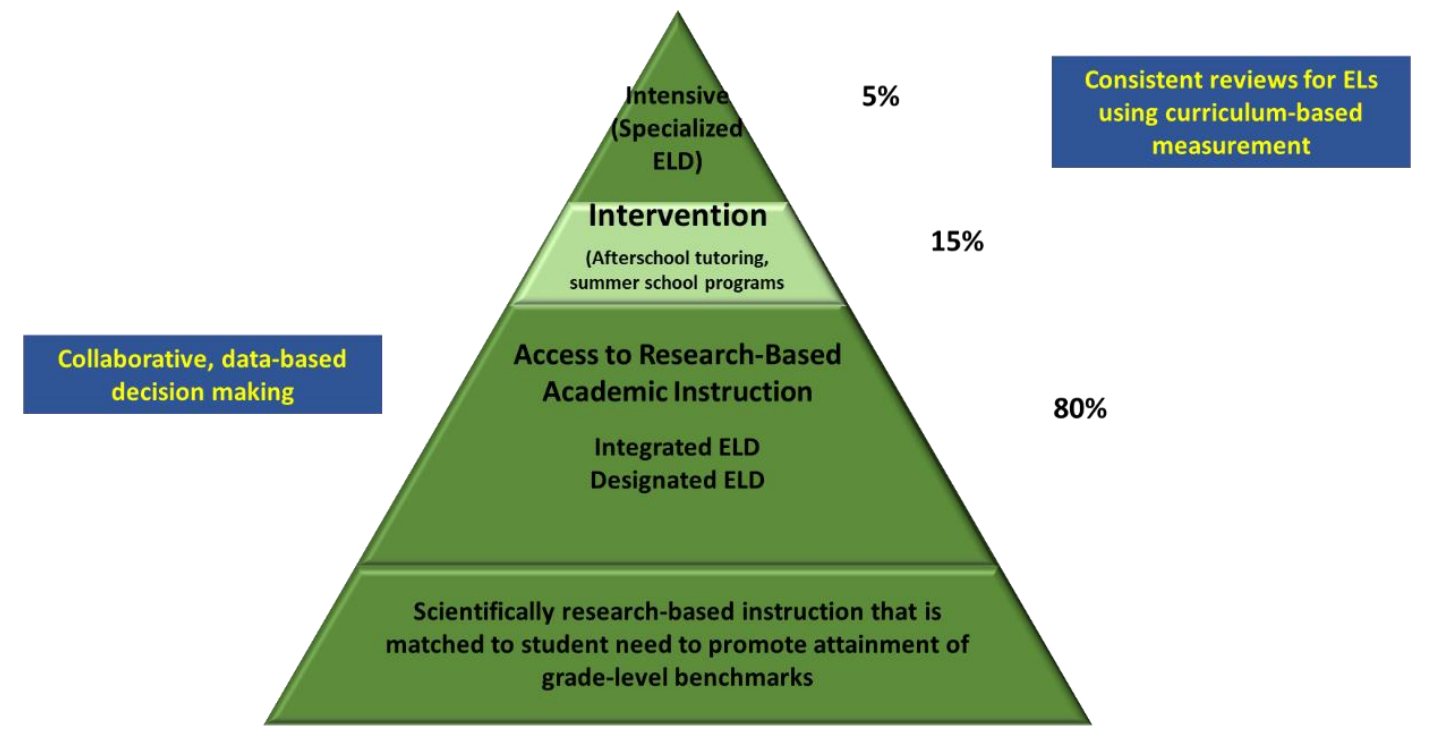

Figure 1: Multi-Tiered System of Supports for English Learners 
Figure A4.6 Program Monitoring and Evaluation: Monitoring Program Implementation. Burbank Unified School District Master Plan for English Learners (202I-24, pages 68-69)

\section{Monitoring Program Implementation}

\section{Expectation 1: Program implementation as described in the Master Plan for English Learners}

District and site staff will monitor implementation of all English learner programs. The primary goal of monitoring is to ensure that every school in the district has effective and compliant programs for English learners.

The monitoring process is designed to:

- Establish high expectations for all students and provide a framework for ensuring that student and organizational outcomes are achieved

- Promote involvement of all stakeholders in all phases of planning, implementation and evaluation activities

- Provide for high levels of coordination between district-level and site-level improvement efforts

- Ensure that program evaluation is an integral part of school improvement initiatives and activities

- Provide a basis for review and modification of the Master Plan for English Learners every five to six years

Monitoring will consist of the following activities:

- Data analysis based on the categories and calculations from the California School Dashboard

Data from the State's Dashboard in the areas of English Language Arts, Mathematics, English Learner Progress, and Graduation Rate (high school only) will be compiled by site EL staff and reported to the site self-review team. It will determine the next steps for school improvement work.

- Monthly classroom observations of the ELD program

Site administrators are responsible for observing in classrooms that have English learners to monitor for implementation of strategies taught in teacher professional development. They complete the observation form and send it to the District Administrator in charge of EL programs.

- Ongoing coaching and staff development support

Site EL staff will organize site staff development and assist with classroom coaching and/or demonstration lessons. They will assist with the collection and review of data, class placements, organizing for ELD instruction, and preparing the annual ELD Program Review. The District English learner TOSA will have lead responsibility for organizing in-depth reviews and any needed follow-up. 
- Annual ELD Program Reviews

The review will be conducted by a team consisting of the site administrator in charge of EL programs and the site's EL staff. Findings will be compiled and used to determine next steps for school improvement work. The team will review placement of EL students in core content areas, ELD groupings by language proficiency levels, and data review and analysis. The team will also discuss the program evaluation questions outlined in figure 10.1 .

\section{Expectation 2: English Learner Access to Core Curriculum}

Each site principal is responsible for ensuring that English learners have access to core curriculum:

- Elementary principals will work with ELD Specialists, Curriculum Specialists, and classroom teachers to determine appropriate placement and instructional setting for English learners. The principal will ensure that every English learner is appropriately placed. The District Administrator in charge of EL Programs will work closely with site principals to review ELD schedules, ELD groupings by language proficiency levels, and instructional minutes.

- Secondary principals will work closely with counselors and site ELD Coordinators in the development of the Master Schedule to ensure that sections reflect the needs of English learners. The District Administrator in charge of EL Programs will work closely with site administrators, counselors, and ELD Coordinators to determine appropriate placements of English learners.

\section{Expectation 3: Mastery of English}

The District Administrator in charge of EL Programs, principals, elementary ELD Specialists, secondary EL Coordinators, and classroom teachers will analyze annual ELPAC results, ELD benchmarks, and other assessment results used to measure progress toward meeting criteria for reclassification.

\section{Expectation 4: Academic Success}

Each site principal will review and analyze SBAC performance data in English Language-Arts and Mathematics. The data will be disaggregated by language proficiency (EL and R-FEP). Principals will also analyze District benchmark data with site staff to determine trends and areas of need, and to develop action plans.

\section{Expectation 5: Parent Engagement}

Sites will report to the district on parent activities (including ELAC) implemented during the year. A Parent Survey will be completed every year and submitted to the district. Data from these forms will then be aggregated to develop a picture of parent involvement in the district as a whole and will guide parental involvement practices. 


\title{
Figure A4.7. Program Monitoring and Evaluation: Evaluation Design - Goals and Evaluation Questions. Oxnard School District Master Plan for Services to English Learners (2019, page I20)
}

\author{
Oxnard School District English Learner Master PIan - Chapter 9 \\ | page 120
}

\begin{tabular}{|c|c|c|}
\hline Goals & Evaluation Questions & Evidence \\
\hline $\begin{array}{l}\text { 1. EL programs are fully } \\
\text { implemented }\end{array}$ & $\begin{array}{l}1.1 \text { Are EL programs fully and consistently implemented in ways that meet } \\
\text { or exceed requirements of state and federal law? (see Chapter } 3 \text { for } \\
\text { program descriptions) } \\
1.2 \text { To what extent is the English Leamer Master Plan utilized by teachers, } \\
\text { administrators and parents as a tool to meet the needs of ELs and staff? }\end{array}$ & $\begin{array}{l}\text { Principal Assurances Checklist } \\
\text { EL Program Reviews } \\
\text { Meeting Agendas } \\
\text { Surveys } \\
\text { Site Visits (District and Site Initiated) } \\
\text { Instructional Schedule Review }\end{array}$ \\
\hline $\begin{array}{l}\text { 2. Parents of ELs and } \\
\text { RFEPs participate } \\
\text { meaningfully in their } \\
\text { children's education }\end{array}$ & $\begin{array}{l}2.1 \text { Are parents of ELs and RFEPs as likely as parents of EOs to participate } \\
\text { in school activities (parent-teacher conferences, volunteer in class, etc.)? } \\
2.2 \text { Is the rate of parent engagement increasing at meetings and parent } \\
\text { conferences? } \\
2.3 \text { What measures are used to ensure that parents are knowledgeable about } \\
\text { EL program placement, language acquisition and their child's academic } \\
\text { progress? }\end{array}$ & $\begin{array}{l}\text { Sign-in sheets } \\
\text { Meeting Agendas } \\
\text { Surveys } \\
\text { Parent Trainings i.e. ELPAC, EL Master } \\
\text { Plan }\end{array}$ \\
\hline $\begin{array}{l}\text { 3. All ELs will master } \\
\text { English }\end{array}$ & $\begin{array}{l}\text { 3.1 Are ELs acquiring English language proficiency at a rate that is } \\
\text { consistent with EL program expectations? } \\
3.2 \text { Are } 75 \% \text { or more of ELs reaching reasonable fluency on the ELPAC in } \\
5 \text { years or less? } \\
3.3 \text { Is the number of LTEL students in grades } 5 \text { through } 8 \text { decreasing by } \\
5 \% \text { annually? }\end{array}$ & $\begin{array}{l}\text { ELPAC assessment results } \\
\text { District developed Summative } \\
\text { Assessment results } \\
\text { Reclassification Data } \\
\text { ELSSA } \\
\text { Language Appraisal Team Monitoring }\end{array}$ \\
\hline $\begin{array}{l}\text { 4. ELs will achieve } \\
\text { academic success } \\
\text { comparable to EOs }\end{array}$ & $\begin{array}{l}\text { 4.1 Are EL students who are currently receiving ELD services progressing } \\
\text { academically relative to program goals or expectations? } \\
4.2 \text { Are EL and RFEP performing academically at a rate that is consistent } \\
\text { with EOs? } \\
4.3 \text { Is there an increase in the percentage of ELs obtaining "C" or better in } \\
\text { core courses in intermediate grades? } \\
4.4 \text { Are ELs proportionally represented in Special Education and GATE } \\
\text { referrals?* }\end{array}$ & $\begin{array}{l}\text { CAASPP ELA, Math (grades 3-8) } \\
\text { District report cards } \\
\text { Participation rates in electives and } \\
\text { extracurricular activities such as Art, } \\
\text { Music, Sports (intermediate grades) } \\
\text { District developed Summative } \\
\text { Assessments } \\
\text { Special Education and Gate data }\end{array}$ \\
\hline $\begin{array}{l}\text { 5. Rates for ELs and RFEPs } \\
\text { in categories indicating } \\
\text { risk for school failure are } \\
\text { no greater than those for } \\
\text { EOs }\end{array}$ & $\begin{array}{l}\text { 5.1 Are ELs and RFEPs overrepresented in the following categories: } \\
\text { Excessive absences and tardiness } \\
\text { Suspensions, expulsions, other discipline } \\
\text { Retentions in grades K-6 } \\
\text { Special Education } \\
\text { Dropouts } \\
\text { Percent standards "Not Mef" or "Nearly Met" on CAASPP } \\
\text { FOR GATE ONLY: Under represented } \\
5.2 \text { Is there an annual decrease in the percentage of ELs and RFEPs for } \\
\text { each of the risk factors defined above? }\end{array}$ & $\begin{array}{l}\text { Attendance Records } \\
\text { Student Records } \\
\text { CAASPP ELA, Math (grades 3-8) } \\
\text { Special Education and Gate data }\end{array}$ \\
\hline $\begin{array}{l}\text { 6. Students enrolled in } \\
\text { alternative programs will } \\
\text { master language skills in } \\
\text { Spanish as well as English }\end{array}$ & $\begin{array}{l}6.1 \text { What percentage of all students (ELs, IFEPs, RFEPS, EOs) } \\
\text { participating in these programs score standards "Met" or "Exceeds" in } \\
\text { reading/language arts and mathematics on the Spanish versions of the state } \\
\text { standards test? } \\
6.2 \text { What percentage of all students (ELs, IFEPs, RFEPS, EOs) } \\
\text { participating in these programs score at the "Met" or "Exceeds" } \\
\text { proficiency level in English Language Arts and Mathematics on the } \\
\text { California Standards Tests? } \\
6.3 \text { What percentage of all students (ELs, IFEPs, RFEPS, EOs) qualify for } \\
\text { the Oxnard School District Seal of Bi-literacy Pathway Award? }\end{array}$ & $\begin{array}{l}\text { Spanish version of state standardized test } \\
\text { CAASPP ELA, Math (grades 3-8) } \\
\text { Bi-literacy Pathway Award Records }\end{array}$ \\
\hline
\end{tabular}

**The state criteria for annual progress on the ELPAC are: for students at level 1-3 overall, gain of one level per year; for students at Level 4 overall, gain on subtest until all are at Level 3 or higher (i.e., reasonable fluency); for students at reasonable fluency, maintenance of that status until reclassified. 


\begin{tabular}{|c|c|}
\hline \multicolumn{2}{|c|}{ Appendix A5. Other Guidance and Resources } \\
\hline Resource & Summary \\
\hline $\begin{array}{l}\text { California English Learner Roadmap } \\
\text { Principles Overview } \\
\text { https://www.cde.ca.gov/sp/el/rm/principles.a } \\
\text { sp }\end{array}$ & $\begin{array}{l}\text { One page overview of the four principles of } \\
\text { the California English Learner Roadmap. }\end{array}$ \\
\hline $\begin{array}{l}\text { California English Learner Roadmap } \\
\text { Implementation Guide and Toolkit } \\
\text { for Administrators: Volumes I-5 } \\
\text { https://www.californianstogether.org/?s=CA } \\
+ \text { EL+Roadmap+Implementation+Guide+an } \\
\text { d+Toolkit+for+Administratorst }\end{array}$ & $\begin{array}{l}\text { There are five volumes in the Toolkit series. } \\
\text { Each one focuses on a specific aspect of the EL } \\
\text { Roadmap, explores the role of administrators } \\
\text { related to that component of the policy, } \\
\text { provides tools for reflection and planning, } \\
\text { incorporates relevant readings, and offers } \\
\text { resources administrators can use to support EL } \\
\text { Roadmap implementation. }\end{array}$ \\
\hline $\begin{array}{l}\text { California English Learner Roadmap: } \\
\text { Toolkits (Elementary, Middle, and } \\
\text { High School) } \\
\text { https://www.californianstogether.org/englis } \\
\text { h-learner-roadmap-toolkits/ }\end{array}$ & $\begin{array}{l}\text { These toolkits are designed to help classroom } \\
\text { teachers understand and make meaning of the } \\
\text { California English Learner Roadmap } \\
\text { policy. They include tools for individual and } \\
\text { collective assessment of practices through the } \\
\text { lens of the EL Roadmap principles, enabling } \\
\text { teachers to hone in on their own professional } \\
\text { learning needs and priorities. Going beyond } \\
\text { the classroom, the tools also help teachers } \\
\text { think about the kinds of supports and services } \\
\text { needed in their school to support English } \\
\text { learners. Finally, each toolkit lists resources } \\
\text { teachers can access for their own learning and } \\
\text { for their participation in school and district } \\
\text { level dialogues about enhancing instructional } \\
\text { practices and programs. }\end{array}$ \\
\hline $\begin{array}{l}\text { Core Social and Emotional Learning } \\
\text { Competencies } \\
\text { https://casel.org/core-competencies/ }\end{array}$ & $\begin{array}{l}\text { The Collaborative for Academic, Social, and } \\
\text { Emotional Learning (CASEL) is a trusted } \\
\text { source for knowledge about high quality, } \\
\text { evidence-based social and emotional learning } \\
\text { (SEL). CASEL supports educators and policy } \\
\text { leaders and enhances the experiences and } \\
\text { outcomes for all PreK-12 students. }\end{array}$ \\
\hline
\end{tabular}




\begin{tabular}{|c|c|}
\hline Appendix A5. & \\
\hline $\begin{array}{l}\text { English Learner Guidance (OELA) } \\
\text { https://www2.ed.gov/about/offices/list/ocr/l } \\
\text { etters/colleague-el-20150I.pdf }\end{array}$ & $\begin{array}{l}\text { Federal guidance document to assist SEAs, } \\
\text { school districts, and all public schools in } \\
\text { meeting their legal obligations to ensure that } \\
\text { EL students can participate meaningfully and } \\
\text { equally in educational programs and services. } \\
\text { This guidance provides an outline of the legal } \\
\text { obligations of SEAs and school districts to EL } \\
\text { students under the civil rights laws. } \\
\text { Additionally, the guidance discusses compliance } \\
\text { issues that frequently arise in OCR and DOJ } \\
\text { investigations under Title VI and the EEOA and } \\
\text { offers approaches that SEAs and school } \\
\text { districts may use to meet their Federal } \\
\text { obligations to EL students. The guidance also } \\
\text { includes discussion of how SEAs and school } \\
\text { districts can implement their Title III grants and } \\
\text { subgrants in a manner consistent with these } \\
\text { civil rights obligations. }\end{array}$ \\
\hline $\begin{array}{l}\text { English Learner Roadmap and } \\
\text { Crosswalk to LCAP } \\
\text { https://www.cde.ca.gov/sp/el/rm/roadmapto } \\
\text { lcap.asp }\end{array}$ & $\begin{array}{l}\text { This crosswalk between the California EL } \\
\text { Roadmap Policy Principles and the eight Local } \\
\text { Control Funding Formula priority areas can } \\
\text { help facilitate alignment of local goals and } \\
\text { policies with the mission, vision, and principles } \\
\text { of the EL Roadmap Policy. }\end{array}$ \\
\hline $\begin{array}{l}\text { Every Student Succeed Act (ESSA) } \\
\text { https://www2.ed.gov/policy/elsec/leg/essa/in } \\
\text { dex.html }\end{array}$ & $\begin{array}{l}\text { This page contains links to the various } \\
\text { documents with regards to ESSA including } \\
\text { various guides such as Parents Guide to ESSA } \\
\text { and various guidance documents including Title } \\
\text { III guidance addressing ELs. }\end{array}$ \\
\hline $\begin{array}{l}\text { Improving Education for Multilingual } \\
\text { and English Learner Students: Research } \\
\text { to Practice - Chapter 7: Creating } \\
\text { Schools and Systems That Support } \\
\text { Asset-Based, High-Quality Instruction } \\
\text { for Multilingual Learners } \\
\text { https://www.cde.ca.gov/sp/el/er/documents/ } \\
\text { mleleducationch7.pdf }\end{array}$ & $\begin{array}{l}\text { Chapter } 7 \text { of this } 2020 \text { CDE publication begins } \\
\text { by presenting a model for aligned continuous } \\
\text { improvement processes that has ML students } \\
\text { at its core to result in positive academic } \\
\text { outcomes. The model highlights the } \\
\text { importance of (I) attending to organizational } \\
\text { culture, (2) focusing on policy and management, } \\
\text { and (3) developing educator capability. It } \\
\text { concludes with concrete next steps for using } \\
\text { the ideas presented in the chapter to facilitate } \\
\text { district and school change. }\end{array}$ \\
\hline $\begin{array}{l}\text { NASEM Report } \\
\text { Promoting the Educational Success of } \\
\text { Children and Youth }\end{array}$ & $\begin{array}{l}\text { Chapter } 2 \text { of this National Academies of } \\
\text { Science, Engineering and Medicine (NASEM) } \\
\text { report focuses on the evolution of federal }\end{array}$ \\
\hline
\end{tabular}




\section{Appendix A5. Other Guidance and Resources \\ Learning English: Promising Futures (2017) - Chapter 2: Policy Context https://www.nap.edu/read/24677/chapter/4}

State Priorities Related Resources https://www.gocabe.org/index.php/commun ications/dacal

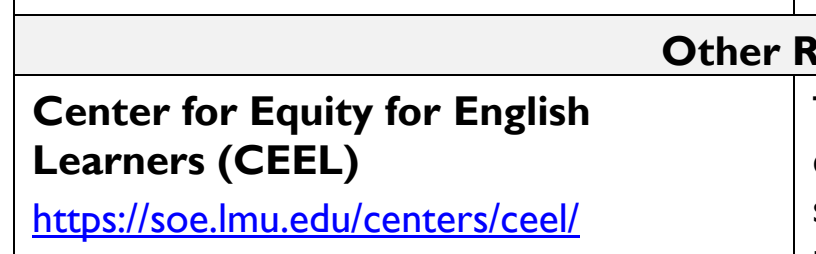

policies that have shaped practice in the education of ELs over the past 50 years, federal and state policies that govern early care and education (ECE) for DLLs and whether they are consistent with promising and effective practices, and current federal and state policies related to K-I 2 education for ELs that have followed the advent of the Every Student Succeeds Act (ESSA) of 2015.

This page in the California Association for Bilingual Education (CABE) website offers resources for DACA students, Safe Haven and Immigration.

\begin{tabular}{|l|l|}
\hline $\begin{array}{l}\text { Californians Together } \\
\text { https://www.californianstogether.org }\end{array}$ & $\begin{array}{l}\text { partners, and policy makers through an assets- } \\
\text { based approach. CEEL provides consistent, high } \\
\text { quality services, programs, resources, and } \\
\text { professional development that promote equity } \\
\text { and excellence for ELs and advance } \\
\text { multilingualism. }\end{array}$ \\
\hline $\begin{array}{l}\text { Californians Together is a statewide advocacy } \\
\text { coalition of organizations from all segments of } \\
\text { the education community including teachers, } \\
\text { administrators, board members, parents and } \\
\text { civil rights non-profit groups. Its various } \\
\text { member organizations coalesce around the } \\
\text { goal of better educating I.I million English } \\
\text { learners by improving California's schools and } \\
\text { promoting equitable educational policy. }\end{array}$ \\
\hline $\begin{array}{l}\text { Ealifornia Association for Bilingual } \\
\text { https://gocabe.org }\end{array}$ & $\begin{array}{l}\text { CABE promotes equity and student } \\
\text { achievement for students with diverse cultural, } \\
\text { racial, and linguistic backgrounds by } \\
\text { implementing initiatives and services designed } \\
\text { to increase California's capacity to create } \\
\text { learning environments that promote } \\
\text { multiliteracy and support English learners. }\end{array}$ \\
\hline
\end{tabular}




\section{ABOUT THE AUTHORS}

Elvira G. Armas, Ed.D., is the Director of Programs and Partnerships for the Center for Equity for English Learners (CEEL) and Affiliated Faculty in the School of Education at Loyola Marymount University, leading and supporting CEEL's P-2I local and national collaborative engagement initiatives.

Throughout her career, Dr. Armas has served as a bilingual classroom teacher, mentor, district advisor, staff developer, grant writer, project director, and curriculum materials developer. She has collaborated with TK-I $2^{\text {th }}$-grade educators in the areas of leadership, curriculum, integrated standards-based instruction, assessment, and family/community engagement in culturally and linguistically diverse settings. She has also co-written numerous national, state, and foundation grant proposals and has served as project director to oversee implementation, development, and research evaluation.

Dr. Armas has co-authored several articles, policy briefs, and book chapters about issues related to teaching, learning, parent/community engagement, and assessment and has taught reading, writing, and second language methods as well as foundational courses at several universities. She holds a Teaching Credential, with Bilingual Authorization in Spanish as well as an administrative credential. She earned an Ed.D. from the University of Southern California with an emphasis in Language, Literacy and Learning.

Magaly Lavadenz, Ph.D., serves as Distinguished Professor of English Learner Policy, Research and Practice in the Department of Educational Leadership and Founding Executive Director of Loyola Marymount University's Center for Equity for English Learners. Previous academic appointments include as Chair of the Teacher Education, Founding Associate Director of LMU's doctoral program in Educational Leadership for Social Justice, and as Founding Director of Spanish and Mandarin Bilingual/Bicultural Teacher Education and TESOL programs.

Dr. Lavadenz has held many leadership positions, including as President of Californians Together, a statewide advocacy organization that promotes quality education for the state's dual language learners and emerging bilingual students, as President of the California Council on Teacher Education, the California Association for Bilingual Education, and as founding president of the California Association of Bilingual Teacher Educators. She engages actively with state, district, county and school partners to support equitable access to quality multilingual education in the state, nation and internationally.

Her research in the areas of educational equity, the preparation and support of teachers and leaders of English learners, Latin@ communities, and biliteracy has been published in journals, book chapters and books, including Latinos and Civil Rights in Education: La Lucha Sigue with Anaida Colón Muñiz. She has served as principal investigator for over 40 grant projects. 
Dr. Lavadenz completed a Ph.D. in Education, specializing in Language, Literacy and Learning, from the University of Southern California. Born in Cuba, Magaly is a former elementary bilingual classroom teacher and K-12 English as a Second Language Teacher Specialist.

Natividad Rozsa, M.A., is an Educational Specialist - Leadership for English Learners with the Center for Equity for English Learners (CEEL) and a Part Time Professional Expert with the California Collaborative for Educational Excellence (CCEE). She retired as Administrator of Instruction for Local District Central, Los Angeles Unified School District (LAUSD) in June 2019 after 42 years of service, having been a teacher assistant, teacher, bilingual and title I coordinator, adviser, specialist, assistant principal, principal, director and administrator of instruction.

As an English learner herself, her passion has been to ensure that all students, particularly those of traditionally under-represented groups realize the American dream, and become successful world citizens. She graduated from USC with a Bachelor of Science, and Cal State University of Los Angeles with a Master degree in Educational Administration.

Gisela O'Brien, Ph.D., is a Biliteracy and English Learner Education Specialist for the Center for Equity for English Learners' efforts and is Affiliated Faculty in the School of Education at Loyola Marymount University. She has worked as a bilingual teacher, staff developer and curriculum/materials designer, and curriculum specialist in the areas of literacy, ELD, and SDAIE. Dr. O'Brien has served as a project advisor and coordinator for several research grants as well as advisor/reviewer at the state and national levels. She has co-authored several articles in educational journals and chapters in books on bilingual education and models for staff development, including a chapter on ELs oral language development in Educating English language learners: A synthesis of research evidence published by Cambridge University Press. 


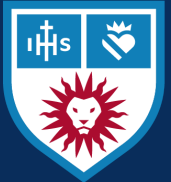

Lovola Marymount Universihy Center for Equity for English Learners 